PONTIFÍCIA UNIVERSIDADE CATÓLICA DE GOIÁS

PRÓ-REITORIA DE PÓS-GRADUAÇÃO E PESQUISA

ESCOLA DE FORMAÇÃO DE PROFESSORES E HUMANIDADES PROGRAMA DE PÓS-GRADUAÇÃO STRICTO SENSU EM EDUCAÇÃO

WEYBER RODRIGUES DE SOUZA

EDUCAÇÃO, CORPO E SENSIBILIDADES: DESVELANDO OS SENTIDOS DO CORPO NOS ESPAÇOS ESCOLARES 
WEYBER RODRIGUES DE SOUZA

\title{
EDUCAÇÃO, CORPO E SENSIBILIDADES: DESVELANDO OS SENTIDOS DO CORPO NOS ESPAÇOS ESCOLARES
}

\author{
Dissertação apresentada ao Programa de \\ Pós-Graduação Stricto Sensu em Educação \\ da Pontifícia Universidade Católica de \\ Goiás, como requisito parcial para a \\ obtenção do título de Mestre em Educação. \\ Orientadora: Dra. Elianda Figueiredo \\ Arantes Tiballi
}


Texto em português, com resumo em inglês

Dissertação (mestrado) -- Pontifícia Universidade Católica de Goiás, Escola de Formação de Professores e Humanidades, Goiânia, 2019

Inclui referências: f. 117-123

1. Educação. 2. Sensibilidade (Traço da personalidade).

3. Teatro escolar. 4. Corpo humano. I.Tiballi, Elianda

Figueiredo Arantes. II.Pontifícia Universidade Católica

de Goiás - Programa de Pós-Graduação em Educação -

2019. III. Título. 


\section{EDUCAÇÃO, CORPO E SENSIBILIDADES: DESVELANDO OS SENTIDOS DO CORPO NOS ESPAC OS ESCOLARES}

Dissertação de Mestrado do Programa de Pós-Graduação Stricto Sensu em Educação da

Pontifícia Universidade Católica de Goiás, aprovada em 27 de setembro de 2019.

\section{BANCA EXAMINADORA}

E) beelli

Profa. Dra. Elianda Figueiredo Arantes Tiballi / PUC Goiás (Presidente)
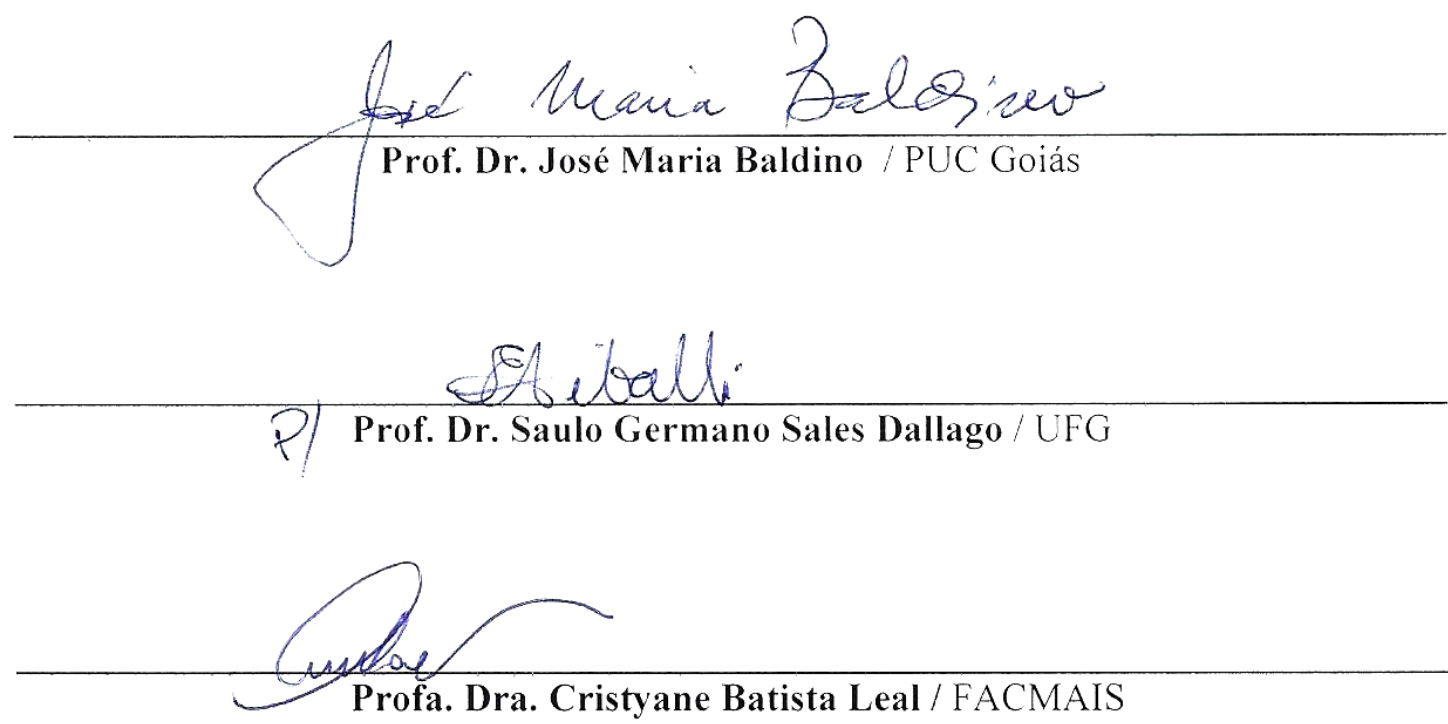

Prof. Dr. João Oliveira Ramos Neto / IF Goiano (Suplente)

Profa. Dra. Raquel Aparecida Marra da Madeira Freitas / PUC Goiás (Suplente) 


\section{AGRADECIMENTOS}

Considerando este trabalho como resultado de uma caminhada que se iniciou antes da minha inserção no Programa de Pós-graduação em Educação da Pontifícia Universidade Católica de Goiás, redigir os agradecimentos torna-se um pouco complicado. Para não correr o risco de cometer injustiças, de antemão agradeço a todos que de alguma forma passaram pela minha vida e contribuíram para a construção da pessoa que sou hoje.

Aos meus familiares pelo acompanhamento de minha trajetória humana e profissional, em especial ao meu avô João Rodrigues dos Santos (em memória).

Aos meus amigos e professores do Colégio Estadual Dom Pedro I, em especial ao meu diretor César de Araújo Pires e ao meu coordenador Gustavo Oliveira Lepize pelo incentivo e apoio prestado durante as visitas de pesquisa na escola.

À toda equipe administrativa e pedagógica da FacCidade - Faculdade Cidade de Aparecida de Goiânia, especial a minha diretora Fátima Rosa Naves e a minha coordenadora Rosilda Campelo dos Santos pelo apoio e parcerias.

À FAPEG - Fundação de Amparo à Pesquisa do Estado de Goiás pelo auxílio financeiro e credibilidade depositada nesta pesquisa.

À CAPES - Coordenação de Aperfeiçoamento de Pessoal de Nível Superior pela bolsa de estudos no exterior, por meio do Programa de Desenvolvimento Profissional para Professores da Educação Básica no Canadá, no qual pude vivenciar múltiplas experiências pedagógicas na educação básica do Canadá, especificamente na cidade de London, província de Ontário.

Aos professores do PPGE/PUC Goiás pelas imensas contribuições teóricas, debates e discussões ao longa do percurso vivenciado na Escola de Formação de Professores e Humanidades da PUC Goiás.

Em especial à professora Dra. Elianda Figueiredo Arantes Tiballi (minha orientadora) pela inspiração e paciência na realização desta pesquisa. Uma pessoa humana que muito colaborou para o meu amadurecimento acadêmico e profissional. 
Aos membros da banca examinadora, Dr. José Maria Baldino, Dr. Saulo Germano Sales Dallago e Dra. Cristyane Batista Leal pelos olhares atentos ao conteúdo desta dissertação e contribuições pertinentes.

Aos integrantes do GEPPEB - Grupo de Estudos e Pesquisa do Pensamento Educacional Brasileiro pelos momentos de estudos coletivo e compartilhamento de múltiplos saberes.

Por fim, menciono o espírito colaborativo dos meus colegas da turma de Mestrado em Educação da PUC Goiás, do ano 2017, pela troca de experiências e saberes sobre a temática corpo e as situações políticas da educação. Em especial, agradeço a minha amiga Kelly Francisca, Ivanildes da Cruz e Rakel Gomes pelas experiências fraternas construídas ao longo da trajetória no PPGE.

A todos os meus sinceros agradecimentos! 
Quando, sobre determinado assunto, a ciência não tem resposta precisa ou saber inquestionável, abre-se o caminho para interpretações poéticas. Temos o dever da poesia e os direitos da imaginação. Sabemos sem saber, e provamos sem provas - apenas razão, simbólica e sensível. 


\section{RESUMO}

A presente pesquisa, vinculado a linha de pesquisa Teorias da Educação e Processos Pedagógicos, tem por finalidade desvelar o sentido e significado da educação do corpo ministrado pela escola, apresentando o Teatro do Oprimido de Augusto Boal como uma possibilidade de educação do corpo com condições mais favoráveis para o despertar de novas sensibilidades. Considerando o corpo como lugar de pesquisa e investigação em diferentes áreas do conhecimento humano, o referido trabalho se apropriou das ideias de cinco autores principais, a saber: Foucault (1987); Duarte Junior (2000); Boal (2009); Le Breton (2010); e Surdi (2018). Em relação aos procedimentos de pesquisa, o referido trabalho utilizou a pesquisa bibliográfica; a etnofotografia; a autobiografia; e a observação. Desse modo, a presente pesquisa está organizada em quatro capítulos. O primeiro capítulo realiza um balanço sobre a produção científica nos Programas de PósGraduação em Educação acerca da temática corpo na escola. O segundo capítulo apresenta uma discussão teórica a respeito do corpo na escola com a finalidade de anunciar um panorama da educação do corpo e das sensibilidades realizado pela escola a partir do olhar de diferentes autores da área da educação. O terceiro capítulo descreve os dados imagéticos e dialoga com os autores tomados como referência nesta pesquisa. O quarto capítulo discorre sobre o teatro como uma possibilidade de educação do corpo na escola, tomando como ponto de partida a teoria do Teatro do Oprimido de Augusto Boal. Por fim, os resultados demonstram que as escolas desenvolvem poucas atividades pedagógicas, onde o corpo seja o centro de todo o processo de aprendizagem escolar. Dificilmente considera-se o corpo escolarizado como um produtor de culturas, sensibilidades, saberes e fazeres.

Palavras-chave: Educação, Corpo, Sensibilidade, Teatro Escolar. 


\begin{abstract}
The purpose, linked to the research line Theories of Education and Pedagogical Processes, of this research is to unfold the meaning of embodied learning and how its taught at school, by presenting Augusto Boal's Theater of the Oppressed as an opportunity of embodied learning with suitable conditions to get different sensations. To consider the body as an instrument of research and investigation in different areas of knowledge, this study was based on ideas from five main authors, such as: Foucault (1987); Duarte Junior (2000); Boal (2009); Le Breton (2010); and Surdi (2018). By this reason, four procedures were used to set the analysis, such as: bibliographic research, ethnography; biography and observation. Consequently, this research was structured in four chapters. The first chapter sets a balance of scientific studies about the embodied learning on Programas de Pós- Graduação em Educação (Post- Graduation Course in Education). The second chapter delivers theoretical background on embodied learning at school, to discuss this theme and its sensations considering the school environment and the theory discussed by different authors from Education studies. The third chapter describes visual data and establishes an intersection with the main authors used as reference in this study. At the end, the last chapter discusses theater as an option of embodied learning at school, using the Theater of the Oppressed by Augusto Boal as start. The results demonstrated how schools develop few pedagogical activities. It is hardly considered the body as a producer of cultures, sensitivities, knowledge and doing.
\end{abstract}

Keywords: Education, Body, Embodied learning, Sensations, Educational theatre. 


\section{LISTA DE IMAGENS}

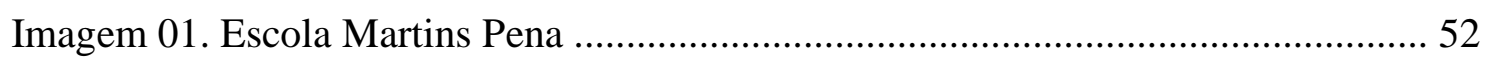

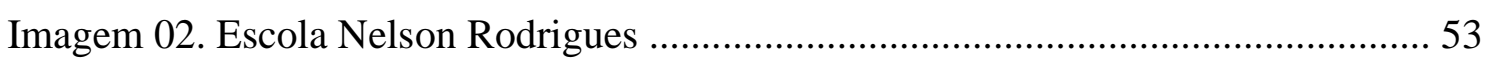

Imagem 03. Siglas e desenhos no muro da Escola Nelson Rodrigues .......................... 53

Imagem 04. Vista externa do muro da Escola Nelson Rodrigues ................................. 56

Imagem 05. Vista interna do muro da Escola Nelson Rodrigues ................................. 56

Imagem 06. Vista do pátio da Escola Maria Clara Machado ...................................... 58

Imagem 07. Bloco novo da Escola Maria Clara Machado ......................................... 58

Imagem 08. Vista anterior da Ficha de Ocorrência Disciplinar .................................. 62

Imagem 09. Vista posterior da Ficha de Ocorrência Disciplinar ................................. 63

Imagem 10. Estudantes cumprindo castigo corporal por desobediência - A ............... 67

Imagem 11. Estudantes cumprindo castigo corporal por desobediência - B .............. 68

Imagem 12. Acesso à Escola Nelson Rodrigues ................................................... 70

Imagem 13. Acesso à Escola Martins Pena ............................................................. 70

Imagem 14. Acesso à secretaria da Escola Nelson Rodrigues: portões fechados ......... 71

Imagem 15. Acesso à secretaria da Escola Nelson Rodrigues: portões abertos ............ 71

Imagem 16 - Acesso à secretaria da Escola Ariano Suassuna - A .............................. 72

Imagem 17. Acesso à secretaria da Escola Ariano Suassuna - B ............................... 72

Imagem 18. Porta da Secretaria da Escola Martins Pena ............................................ 73

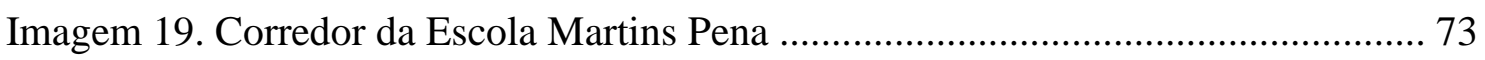

Imagem 20. Um dos portões de entrada da Escola Maria Clara Machado .................... 74

Imagem 21. Portão de entrada da Escola Martins Pena .............................................. 74

Imagem 22. Quadra de esportes da Escola Ariano Suassuna .................................... 76

Imagem 23. Espaço de convivência da Escola Maria Clara Machado .......................... 76

Imagem 24. Quadra de esportes Nelson Rodrigues-2: espaço destinado a práticas de

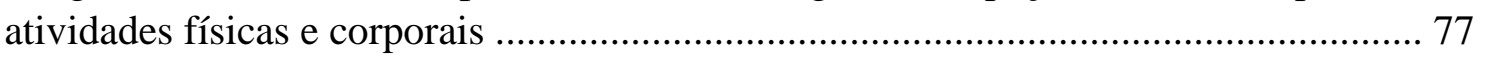

Imagem 25. Quadra de esportes e atividades físicas da Escola Martins Pena ............... 78 
Imagem 26. Espaço destinado a prática de esportes e atividades físicas da Escola Nelson Rodrigues-1

Imagem 27. Estudantes da Escola Nelson Rodrigues aguardando o sinal da professora para iniciar uma partida de queimada 80

Imagem 28. Cartaz informativo fixado no mural de avisos da Escola Maria Clara Machado 82

Imagem 29. Uniforme sexista adotado pela Escola Maria Clara Machado 82

Imagem 30. Relatório da coordenação da Escola Nelson Rodrigues acerca da pichação realizada por um aluno 84

Imagem 31. Pichação na parede de uma das salas da Escola Nelson Rodrigues-1 ....... 85

Imagem 32. Pichação na parede de uma das salas da Escola Nelson Rodrigues-2 ....... 87

Imagem 33. Pichação na parede de uma das salas da Escola Nelson Rodrigues-3 ....... 88

Imagem 34. Pichação na parede de uma das salas da Escola Nelson Rodrigues-4 ....... 89

Imagem 35. Pichação na parede de uma das salas da Escola Nelson Rodrigues-5 ....... 90

Imagem 36. Pichação na porta do banheiro da Escola Nelson Rodrigues .................... 91

Imagem 37. Foto de Augusto Boal extraída da capa de um de seus livros intitulado $A$ estética do Oprimido publicado pela Editora Garamond, na cidade do Rio de Janeiro em 2009 99

Imagem 38. Montagem de texto dramático e ensaio da proposta na Escola Nelson Rodrigues 113

Imagem 39. Organização do pátio da Escola Nelson Rodrigues para o fórum 113 


\section{LISTA DE QUADROS, TABELAS E GRÁFICOS}

Quadro 1. Teses e dissertações selecionadas na Biblioteca Digital de Teses e

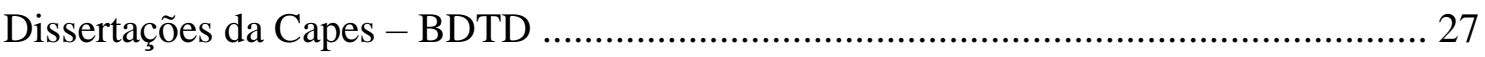

Quadro 2. Principais obras publicadas por Augusto Boal ........................................ 100

Quadro 3. Síntese da análise das teses e dissertações da BDTD-Capes ...................... 125

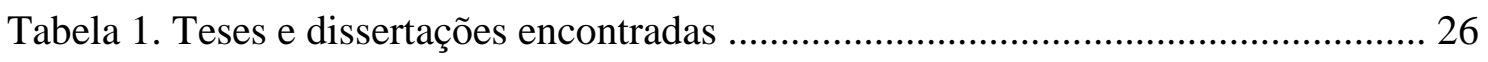

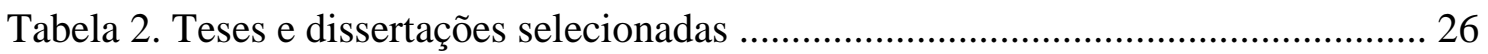

Gráfico 1. Distribuição de trabalhos: dissertações e teses ............................................. 27

Gráfico 2. Ponto nuclear de discussão das teses e dissertações .................................... 30

Gráfico 3. Base teórica: principais autores utilizados ................................................... 34 


\section{LISTA DE ABREVIATURAS}

ANPED Associação Nacional de Pós-Graduação e Pesquisa em Educação

CAPES Coordenação de Aperfeiçoamento de Pessoal de Nível Superior

FAPEG $\quad$ Fundação de Amparo à Pesquisa do Estado de Goiás

GEPPEB Grupo de Estudos e Pesquisa do Pensamento Educacional Brasileiro

PPGE Programa de Pós-Graduação em Educação

PUC Goiás Pontifícia Universidade Católica de Goiás

SEDUCE Secretaria de Estado da Educação, Cultura e Esportes 


\section{SUMÁRIO}

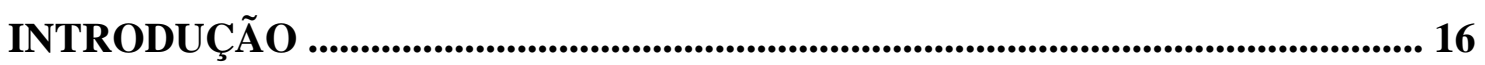

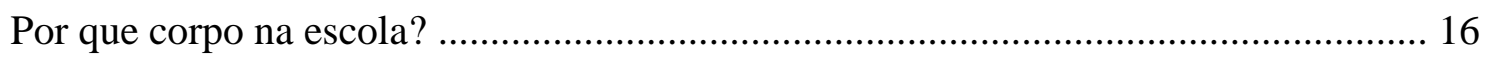

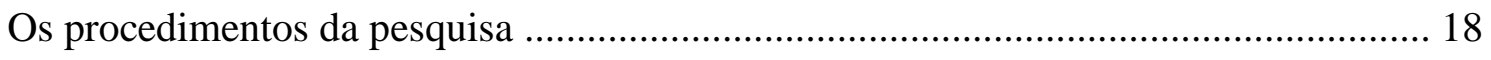

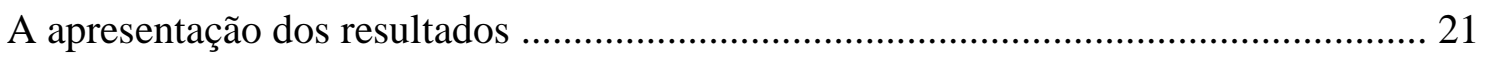

CAPÍtUlO I - BALANÇO SOBRE O CONCEITO DE CORPO NOS TRABALHOS EM EDUCAÇÃO .............................................................................................. 22

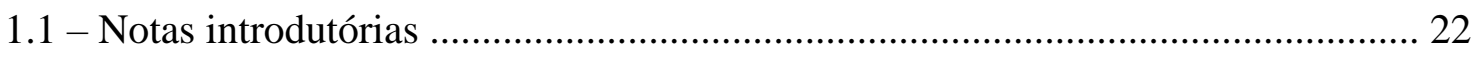

1.2 - O corpo nos trabalhos de pesquisa de Pós-Graduação em Educação ................... 25

CAPÍTULO II - EDUCAÇÃO, CORPO E SENSIBILIDADE NA ESCOLA: DIZERES E FAZERES .......................................................................................... 36

2.1 - O corpo escolarizado: o que dizemos e o que fazemos ...................................... 36

CAPÍTULO III - O CORPO NA ESCOLA: RUPTURAS E CONTINUIDADES 50

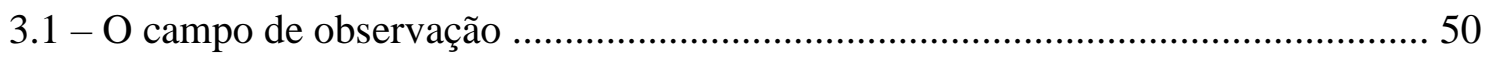

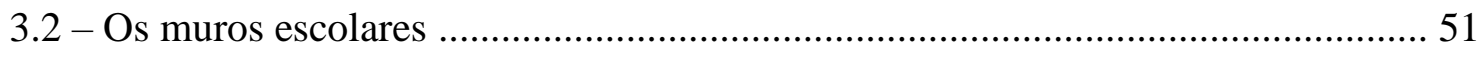

3.3 - A estrutura física interna: algumas revelações ................................................... 57

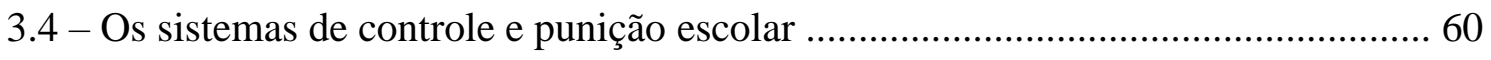

3.5 - O tempo da aprendizagem corporal na escola ................................................ 79

3.6 - O controle das vestimentas e adereços corporais ............................................ 81

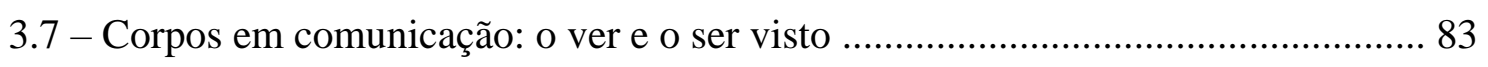

CAPÍtulo IV - TEATRO NA ESCOLA: UM LUGAR PARA PENSAR A EDUCAÇÃO DO CORPO E DAS SENSIBILIDADES ....................................... 93 
4.1 - Teatro na escola: para encenar ou para ensinar? ............................................ 94

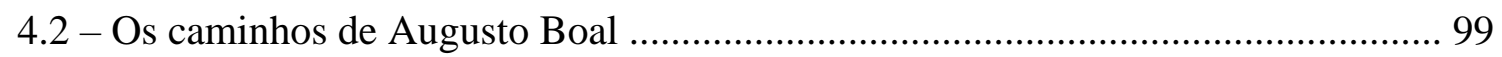

4.3 - Os componentes do Teatro do Oprimido .......................................................... 102

4.4 - O Teatro do Oprimido como possibilidade de educação do corpo na escola ..... 104

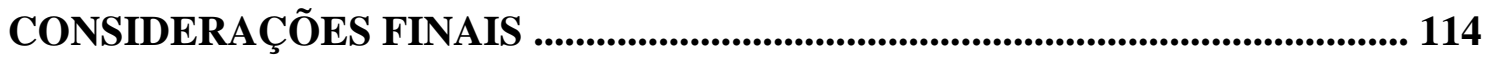

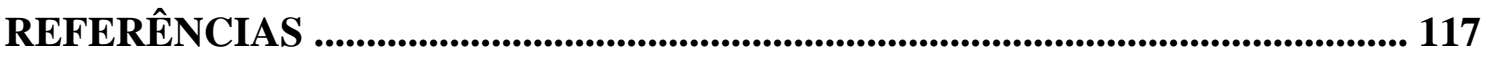

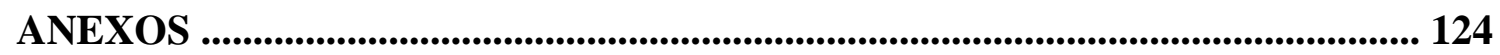




\section{INTRODUÇÃO}

A arte não deve continuar encerrada em museus, teatros e salas de concerto para visitação de fim de semana, pois é necessária em todas as atividades humanas, no trabalho, no estudo e no lazer. Não deve ser atributo de eleitos: é condição humana. Não é maquiagem na pele: é sangue que corre em nossas veias.

Augusto Boal.

\section{POR QUE O CORPO NA ESCOLA?}

Nasci em Goiás num povoado interiorano, localizado próximo ao Rio Araguaia. Fui criado por uma família de trabalhadores rurais desprovidos de oportunidades. Meus pais, pessoas simples e humildes, foram letrados, mas nunca concluíram o Ensino Fundamental. A árdua rotina de trabalho com a terra, somada às dificuldades de acesso à produção humana, nos negaram muitas vivências corporais. Pouco sabíamos sobre as artes, as culturas e os esportes.

Aos meus dois anos de idade, por conta da crescente industrialização do campo, fomos forçados a nos mudar para a periferia da cidade de Goiânia. Nesta cidade, frequentei escolas públicas durante toda a minha trajetória escolar. Conheci no Ensino Médio uma professora de Geografia defensora da liberdade, da democracia e dos direitos das minorias. Ela era negra, militante e de luta. O contato com a sua prática pedagógica me despertou o desejo pela docência. Cursei Licenciatura em Geografia na Pontifícia Universidade Católica de Goiás em 2005 e me ingressei na profissão docente nos anos seguintes.

Minhas primeiras experiências na carreira docente ocorreram numa escola pública da periferia de Goiânia. Era uma escola pequena, carente e marcada pela criminalidade. Eu ensinava Geografia, Artes e Educação Física para crianças do Ensino Fundamental e Médio. Admito que ministrar disciplinas fora da minha área de formação 
me causava um grande desconforto. Me restaram duas alternativas: abandonar as aulas e perder o emprego ou cursar uma segunda licenciatura. Optei pelos estudos. Iniciei em 2011 o curso de Licenciatura em Artes Cênicas pela Universidade Federal de Goiás. De início, confesso o quanto os estudos teatrais provocaram estranhamentos e conflitos internos acerca do meu "eu" e do meu corpo. Eram processos de educação do corpo e das sensibilidades, com finalidades direcionadas para a formação de uma consciência corporal e uma poética do movimento.

Os exercícios de aquecimento, alongamento, sensibilidade, percepção e contato com outros corpos eram provocativos. Buscavam o rompimento de tabus, despertavam novas sensações, atitudes, valores e aprendizados. Posso dizer que o meu interesse pela temática corporal nasceu aqui, no teatro, especificamente nas disciplinas de Artes do Corpo. As discussões teóricas realizadas eram provocantes e desafiadoras. Tratavam do corpo como um lugar único e em permanente processo de construção. Abordavam conceitos que remetiam à ideia de corpo como lugar de expressão, de fala, de transmissão, de recepção, de omissão, de sentimentos e de sensibilidades. Um corpo que na sua aparência transcendesse à essência. Um corpo que nas artes estaria em toda parte. Um corpo enérgico que não se desvincularia do movimento e da ação e, por isso, se configurava como lugar da nossa morada e da nossa existência material.

As preocupações com o corpo se intensificaram com a minha inserção na especialização em Gênero e diversidade na escola oferecido pela Universidade Federal de Goiás - Campus Catalão no ano de 2013. Havia um desafio: compreender o lugar do corpo em uma sociedade patriarcal reinada pelo silenciamento das minorias étnicas, pelo privilégio heteronormativo, pelo estabelecimento de padrões de comportamento e pelo controle social do corpo e da sexualidade. Toda essa trajetória me trouxe para o curso de Mestrado em Educação do Programa de Pós-Graduação em Educação da Pontifícia Universidade Católica de Goiás - PUC Goiás em 2017. Inicialmente, a proposta de pesquisa para o referido programa foi a busca pelo entendimento das contribuições do teatro escolar para a promoção da equidade de gêneros. Contudo, muitas questões foram levantadas a partir de leituras, participação em eventos, orientações e discussões realizadas no Grupo de Estudos e Pesquisa do Pensamento Educacional Brasileiro - GEPPEB, coordenado pela Professora Dra. Elianda Figueiredo Arantes Tiballi (PPGE/PUC Goiás). 
Com essa interação, percebi que discutir o conceito de gênero no teatro escolar não traria respostas para uma problemática maior que é o corpo na escola. Primeiro porque é da natureza do teatro a incorporação de questões de gênero. Os corpos cênicos representam masculinidades e feminilidades independente do sexo biológico, afinal, este é o movimento do teatro: uma atividade estética múltipla, acolhedora e aberta às múltiplas sensibilidades de gênero. Em outras palavras, ao serem submetidos a atividades teatrais, cada sujeito assume diferentes perspectivas sobre o que é ser homem e o que é ser mulher numa dada sociedade. Isso, de modo geral, representa as contribuições do teatro escolar para a equidade de gêneros no contexto escolar.

Assim, mais do que dizer sobre as questões de gênero na escola, é preciso entender o corpo nos processos ritualizados do ensino escolar, pois, se levarmos em consideração que um corpo sensível é um corpo capaz de compreender a diversidade sociocultural a qual estamos inseridos, parece-me mais urgente entender sobre o lugar do corpo na escola em espaços e tempos distintos. Dessa premissa, emergiu uma questão que representa o problema deste estudo: Qual é o sentido e o significado da educação do corpo pela escola?

Com base no problema levantado, esta pesquisa tem como objetivo geral analisar a educação do corpo e das sensibilidades promovida por algumas escolas estaduais da região central da cidade de Aparecida de Goiânia-Go. Nesse sentido, os objetivos específicos visam: a) caracterizar os espaços escolares e seus usos na educação do corpo e das sensibilidades; b) diagnosticar o modo pelo qual a escola opera os sistemas de controle e punição dos corpos escolarizados; c) referenciar o teatro escolar como uma possibilidade de educação do corpo para o despertar de novas sensibilidades.

\section{OS PROCEDIMENTOS DA PESQUISA}

Considerando o corpo como lugar de pesquisa e investigação em diferentes áreas do conhecimento humano, partimos para uma análise social do corpo na escola a partir das ideias de cinco autores principais: Foucault (1987); Duarte Junior (2000); Boal (2009); Le Breton (2010); e Surdi (2018), dos quais compõem um conjunto de ideias fundamentais para o desenvolvido deste estudo. 
No cenário acadêmico, a enorme procura por cursos, seminários, encontros científicos e especializações envolvendo a temática corpo pode nos explicar sobre a grande preocupação do campo da educação em buscar entendimentos para essas questões. Por esse motivo, o presente trabalho utilizou quatro procedimentos de pesquisa. O primeiro refere-se a pesquisa bibliográfica. De acordo com Prodanov (2013), a pesquisa bibliográfica ocorre quando é:

elaborada a partir de material já publicado, constituído principalmente de: livros, revistas, publicações em periódicos e artigos científicos, jornais, boletins, monografias, dissertações, teses, material cartográfico, internet, com o objetivo de colocar o pesquisador em contato direto com todo material já escrito sobre o assunto da pesquisa. Em relação aos dados coletados na internet, devemos atentar à confiabilidade e fidelidade das fontes consultadas eletronicamente. Na pesquisa bibliográfica, é importante que o pesquisador verifique a veracidade dos dados obtidos, observando as possíveis incoerências ou contradições que as obras possam apresentar (PRODANOV, 2013, p.54).

A partir da exposição textual deste autor, considerou-se a pesquisa bibliográfica como um procedimento necessário, pois, além de fundamentar teoricamente o objeto em investigação, permitiu também uma análise mais aprofundada sobre os dados obtidos. Conforme Koche (1997), a pesquisa bibliográfica pode ser realizada com base em diferentes finalidades:

a) para ampliar o grau de conhecimentos em uma determinada área, capacitando o investigador a compreender ou delimitar melhor um problema de pesquisa; b) para dominar o conhecimento disponível e utilizá-lo como base ou fundamentação na construção de um modelo teórico explicativo de um problema, isto é, como instrumento auxiliar para a construção e fundamentação de hipóteses; c) para descrever ou sistematizar o estado da arte, daquele momento, pertinente a um determinado tema ou problema (KOCHE, 1997, p.122).

É importante ressaltar que as finalidades apresentadas por Koche (1997) se fizeram presentes nesta pesquisa em diferentes momentos.

O segundo procedimento adotado nesta pesquisa refere-se à análise iconográfica e iconológica, conhecida pelo uso de fotografias, da qual diversas pesquisas em educação têm se apropriado por conta da riqueza de informações investigativas que apresenta. Segundo Panofsky (1976, p.64), “a análise iconográfica utiliza o mundo das imagens, estórias e alegorias, enquanto a interpretação iconológica utiliza o mundo dos valores simbólicos". O uso desses procedimentos tem sido comum 
nas pesquisas sobre a arquitetura escolar, os espaços de convivência na escola, o cotidiano escolar, a organização pedagógica dos ambientes de aprendizagem escolar, bem como para desvelar a etnografia no contexto educacional. Sobre o uso da fotografia nos trabalhos sobre a educação, Tiballi e Jorge (2007) salientam que:

\begin{abstract}
Ao introduzir a fotografia no processo investigativo, o pesquisador, a partir da orientação antropológica, poderá resolver o problema da observação através do registro imagético. Os resultados da observação certamente terão rigor científico e as informações serão precisas, pois, através da objetividade da fotografia os dados denotados fornecem elementos que, muitas vezes, a objetividade da informação numa simples vista, deixa escapar. [...] Assim, a fotografia, além de fornecer os detalhes que constituem a essência do objeto, esmera a observação através do próprio exercício de fotografar (TIBALLI e JORGE, 2007, p. 72).
\end{abstract}

Ao realizarem a afirmação acima, os autores contribuem para reforçar a relevância da fotografia como fonte de pesquisa científica para o campo da educação, uma vez que este recurso imagético permite uma representação espaço-temporal do objeto investigado. Ainda de acordo com os autores:

O que está representado na fotografia representa também a experiência visual do observador [...] e a observação fotográfica, ao contrário dos relatos pessoais, corresponde a uma epistemologia do visual, donde a realidade dinâmica e corpórea é fundante de uma didática culturalmente visual (TIBALLI e JORGE, 2007, p. 73).

Desse modo, a fotografia constituiu-se como um recurso para a coleta de dados nas escolas investigadas. Por conta disso, o material fotográfico presente neste trabalho, representa parte dos dados observados durante as observações e visitas realizadas no período de outubro de 2018 a março de 2019. É importante salientar que as fotografias presentes no referido trabalho foram selecionadas, levando em consideração a natureza de expressão da realidade investigada. $\mathrm{O}$ terceiro procedimento adotado refere-se à narrativas autobiográficas, entendida como:

Uma construção e configuração da própria identidade, mais do que um relato fiel da própria vida, que sempre está em projeto de chegar a ser. A autobiografia oferece um terreno onde explorar os modos como se concebe o presente, divisa-se o futuro, e - sobretudo - se conceitualiza as dimensões intuitiva, pessoal, política e social da experiência educativa. (BRASILEIRO, 2008, p.07). 
Partindo desse pressuposto, analiso minhas práticas pedagógicas como professor de Geografia e Teatro em uma escola pública localizada na periferia da cidade de Aparecida de Goiânia-Go. De modo geral, esse procedimento de pesquisa tem sido utilizado com bastante frequência no campo na educação, principalmente nos estudos dedicados a formação de professores.

Ainda, esta pesquisa utilizou a observação como procedimento de pesquisa, entendida como uma forma de coletar dados empíricos para pesquisas qualitativas. De acordo com Lima, Almeida e Lima (1999), a observação é importante porque possibilita "um contato pessoal do pesquisador com o objeto de investigação, permitindo acompanhar as experiências diárias dos sujeitos e apreender o significado que atribuem à realidade e às suas ações" (LIMA, ALMEIDA e LIMA, 1999, p.131). Por conseguinte, esse procedimento de pesquisa tem sido bastante utilizado em pesquisas de diferentes áreas do conhecimento humano.

\section{A APRESENTAÇÃO DOS RESULTADOS}

A presente pesquisa está organizada em quatro capítulos. O primeiro capítulo realiza um balanço sobre a produção científica nos Programas de Pós-Graduação em Educação acerca da temática corpo na escola. Nesse capítulo, são apresentados dados quantitativos a fim de demonstrar o que tem sido produzido sobre a temática nos últimos anos. O segundo capítulo apresenta uma discussão teórica acerca do corpo na escola. A finalidade deste capítulo é apresentar um panorama da educação do corpo realizado pela escola a partir do olhar de diferentes autores da área da educação. Também é apresentada uma discussão sobre o conceito de sensibilidade no campo da educação escolar. O terceiro capítulo descreve os dados imagéticos e dialoga com os autores tomados como referência nesta pesquisa. Por fim, o último capítulo discorre sobre o teatro como uma possibilidade de educação do corpo na escola. Dessa maneira, o quarto capítulo toma os conceitos de Teatro do Oprimido de Augusto Boal como um caminho para a educação do corpo na escola rumo ao despertar de novas sensibilidades. 


\section{CAPÍTULO I - BALANÇO SOBRE O CONCEITO DE CORPO NOS TRABALHOS EM EDUCAÇÃO}

Os que oprimem impõem aos oprimidos sua visão do mundo e de cada coisa desse mundo, para que sejam obedecidos e reine a sua paz.

Para se libertarem, os oprimidos devem descobrir sua própria visão da sociedade, suas necessidades, e contrapô-las à verdade dominante, opressiva.

Augusto Boal.

Com a finalidade de dialogar sobre a produção científica no campo da educação acerca da temática corpo na escola, este capítulo apresenta dados qualitativos e quantitativos oriundos do levantamento bibliográfico realizado na BDTD - Biblioteca Digital de Teses e Dissertações da Capes, compreendendo os anos de 2013 a 2017. De modo geral, esse percurso possibilitou ampliar horizontes e perspectivas acerca do objeto investigado.

\section{1 - Notas introdutórias}

Corpo: o lugar da nossa morada! O lugar do mistério, das dúvidas, do não revelado, do oculto, do desconhecido, do estranhamento, do inesperado, das experiências, do vivido. É, ainda, o lugar do movimento, da ação, do pensamento, das emoções, dos sentimentos e da nossa existência única e particular. É, de modo geral, o lugar da nossa manifestação física, biológica, artística, social, política e cultural. Em outras palavras, é o lugar da nossa existência humana. Somos, por conseguinte, corpos submetidos a constantes processos de aprendizagens de comportamentos, sensações, movimentos, gestos e sabores (Le Breton, 2012). Sendo assim, nosso corpo é uma 
construção social, fruto das diversas manifestações culturais que corporificam a nossa expressividade humana e que revelam por alguns instantes quem nós somos. Mas é preciso ir além disso para compreender o corpo que carregamos todos os dias. É preciso conhecer nossa essência, entender nossas sensibilidades, superações, dores, limitações, lutas, resistências, transformações e formas de sobrevivência. Portanto, é preciso conhecer nossa condição humana.

De modo geral, parece haver poucos lugares para a sensibilidade corporal ou, pelo menos, ela é negada para uma significativa parcela da população desprovida de recursos financeiros. Em outros momentos, a sensibilidade parece assumir uma condição mercadológica. Essa afirmação parece um pouco estranha, mas se concordarmos com Le Breton (2012) de que a nossa existência é, antes de tudo, corporal, podemos afirmar que nossa sensibilidade está condicionada a aquilo que nos é permitido, enquanto corpo, conhecer, vivenciar, experimentar, sentir e expressar. Logo, o despertar de nossa sensibilidade está condicionada àquilo que é permitido ao nosso corpo. Moura et al (2016), ao estudar sobre o desenvolvimento do corpo humano apoiado nas ideias de Vigotski, evidencia os segmentos constituintes do corpo humano, sendo este um campo formado pelos aspectos afetivo, cognitivo, social e motor. Nas palavras dos autores, o corpo humano:

não é determinado apenas por processos de maturação biológicos ou genéticos, mas, também, pelo meio, que envolve cultura, sociedade, práticas e interações, os quais são fatores de máxima importância no desenvolvimento humano. (MOURA et al, 2016, p.107).

Em concordância com as afirmações acima, nota-se que a sensibilidade é da natureza do humano, podendo sofrer determinações advindas da sociedade e cultura a qual está inserido. Para ser ampliada, cabe, portanto, provocar múltiplas vivências corporais. Assim afirma Santin:

\footnotetext{
Não acredito que se entenda a sensibilidade através de uma representação mental contida em definições, mas na contemplação dos fatos onde foi vivenciada ou, talvez, com maior riqueza, nos momentos que nós mesmos, cada um de nós, a experienciou de maneira intensa. Não são os discursos que nos oferecem a compreensão da sensibilidade, mas a sua vivência (SANTIN, 1997, p.04).
}

Percebemos, nas palavras de Santin (1997), que a sensibilidade não pode ser palpável, mas advém das experiências acumuladas pelos sujeitos ao longo da vida. Mas 
penso que, se a sensibilidade é desenvolvida pelas condições que lhe são permitidas vivenciar, a emergência de entendê-la no contexto corporal emerge como uma necessidade marcante. Nesse contexto, o corpo é condição primeira para a árdua tarefa de buscar compreensões para a questão da sensibilidade, sendo objeto de investigação que pode nos endereçar para a compreensão da sensibilidade humana. Assim, o corpo investigado é um corpo que, pela sua natureza, assume uma simbologia que lhe é própria e que é carregada de múltiplos significados.

Como objeto de pesquisa, o corpo está presente nas artes, nas ciências humanas, na biologia, na saúde, na economia, na cultura e na educação. Por conta disso, ganha inúmeros olhares e perspectivas, cada qual ao seu modo, ao seu tempo, ao seu lugar. É, sem dúvidas, um campo em constantes transformações.

Tal fato exige novas abordagens por parte das ciências interessadas na compreensão deste objeto. Desse modo, esta pesquisa tem a pretensão de analisar o corpo escolarizado, seus ritos, sua conduta na cultura escolar e o desenvolvimento de suas sensibilidades por meio da linguagem cênica. $O$ teatro, como possibilidade de educação das sensibilidades, tem muito a dizer sobre o corpo. Para o teatrólogo Augusto Boal (2009) “o pensamento sensível, que produz arte e cultura, é essencial para a libertação dos oprimidos, amplia e aprofunda sua capacidade de conhecer" (BOAL, 2009 , p.16). Em outras palavras, não se faz teatro sem uma relação corporal porque o teatro é corpo, é presença, é movimento e nos permite ampliar nossos conhecimentos e percepções acerca da realidade. De acordo com Lima (2010), o aluno que participa de atividades teatrais na escola terá:

\footnotetext{
A oportunidade de vivenciar a prática teatral, doando o seu corpo a novas experiências e transformações, além disso, possibilitará a convivência social, em que o indivíduo, pela prática da representação, expõe-se e confronta o seu mundo com o mundo que o cerca. [...] Fazer teatro é muito mais que estar em cena, que estar no palco, é se inteirar dos princípios norteadores dessa arte, é vivenciar as situações é transformar seu corpo num instrumento de representação, é dar vida a personagens na mais pura essência. [...] Para fazer teatro é necessário um tempo. Tempo de preparação, de maturidade, de pertencimento, de trabalho. É necessário um corpo que traz em si um mundo vivido e deve estar aberto para novos mundos a serem vivenciados. Um corpo e sua essência são únicos, singulares e, sem o corpo do ator, não há teatro (LIMA, 2010, p.88).
}

Após estas breves considerações, é possível notar a relevância da prática corporal no teatro escolar para o desenvolvimento motor, cognitivo e afetivo dos estudantes. Pode-se, a partir disso, questionar os corpos que os estudantes levam para as 
aulas de teatro, os movimentos limitados, mecânicos e os tabus impregnados em suas condutas corporais.

Nessas circunstâncias, antes de qualquer avanço científico, é preciso situar as discussões sobre o corpo na escola, de modo a perceber as abordagens teóricometodológicas assumidas nas pesquisas e nas discussões acadêmicas da contemporaneidade. Tal exercício se faz necessário para uma efetiva compreensão dos sentidos tomado pelas pesquisas envolvendo a temática corpo no contexto educacional. Com essa finalidade, realizou-se um balanço sobre as discussões científicas efetuadas no campo da educação nos últimos anos sobre o conceito de corpo.

\section{2 - O corpo nos trabalhos de pesquisa em Pós-Graduação em Educação}

Devido ao grande número de Programas de Pós-Graduação em Educação e a significativa produção resultante de pesquisas de dissertações e teses, bem como o fato de que nem todos esses trabalhos são divulgados por meio de outras publicações, a pesquisa teve como fonte de consulta a Biblioteca Digital de Teses e Dissertações (BDTD) da Coordenação de Aperfeiçoamento de Pessoal de Nível Superior (Capes), que disponibiliza integralmente as teses e dissertações defendidas em Programas de Pós-Graduação no país.

A opção por essa base de dados justifica-se também por outros faces, dentre eles: a) permite uma abrangência nacional, considerando-se a existência de Programas de Pós-Graduação em todas as regiões do país; b) os Programas dedicam-se em grande parte à formação de professores e ao seu desenvolvimento para a atuação no ensino e na pesquisa, concentrando grande parte da pesquisa sobre os temas educacionais e, particularmente, sobre o corpo na escola; c) a avaliação contínua dos Programas de PósGraduação pela Capes e, consequentemente, a qualidade acadêmica e científica das dissertações e teses.

Para a realização desta tarefa, inicialmente adotou-se o parâmetro linguístico (somente obras no idioma português). Realizou-se um recorte temporal para a busca e identificação das teses e dissertações da BDTD, abrangendo os anos de 2013 a 2017. Foram utilizados os seguintes descritores mais amplos: educação corporal; corpo; espaços escolares. 
Para direcionar a pesquisa para o campo da educação, foram aplicados os seguintes filtros na BDTD: a) Grande área do conhecimento: Ciências Humanas; b) Área do conhecimento: Educação; c) Área de concentração: Educação. Foram encontrados 1584 trabalhos, destes sendo 1095 dissertações de mestrado e 489 teses de doutorado, conforme tabela abaixo:

Tabela 1 - Teses e dissertações encontradas após o uso dos descritores e filtros.

\begin{tabular}{l|c|c|c|c|c|c}
\hline \multicolumn{1}{c|}{ Ano } & $\mathbf{2 0 1 3}$ & $\mathbf{2 0 1 4}$ & $\mathbf{2 0 1 5}$ & $\mathbf{2 0 1 6}$ & $\mathbf{2 0 1 7}$ & Total \\
\hline Dissertações & 242 & 216 & 186 & 298 & 153 & 1095 \\
\hline Teses & 106 & 87 & 98 & 122 & 76 & 489 \\
\hline TOTAL & $\mathbf{1 0 2}$ & $\mathbf{1 4 3}$ & $\mathbf{1 0 1}$ & $\mathbf{1 3 1}$ & $\mathbf{1 0 8}$ & $\mathbf{1 5 8 4}$ \\
\hline
\end{tabular}

Fonte: Tabela elaborada à partir dos dados da Coordenação de Aperfeiçoamento de Pessoal do Ensino Superior - Capes - BDTD

Para a seleção das teses e dissertações, utilizou-se como critério o parâmetro temático: a) a relação com o objeto de pesquisa; b) a temática abordada na obra; c) os temas correlatos ao objeto de pesquisa. Por meio da leitura exploratória (nos resumos, índices e considerações finais) verificou-se a relevância das obras para a pesquisa, eliminando aquelas que possuíam pouca ou nenhuma relação com o objeto de estudo. Após esse procedimento, foram selecionados 39 trabalhos, conforme tabela abaixo:

Tabela 2 - Teses e dissertações selecionadas por meio de critérios pré-estabelecidos

\begin{tabular}{l|c|c|c|c|c|c}
\hline \multicolumn{1}{c|}{ Ano } & $\mathbf{2 0 1 3}$ & $\mathbf{2 0 1 4}$ & $\mathbf{2 0 1 5}$ & $\mathbf{2 0 1 6}$ & $\mathbf{2 0 1 7}$ & Total \\
\hline Dissertações & 08 & 07 & 02 & 05 & 06 & 28 \\
\hline Teses & 04 & 01 & 01 & 03 & 02 & 11 \\
\hline TOTAL & $\mathbf{1 2}$ & $\mathbf{0 8}$ & $\mathbf{0 3}$ & $\mathbf{0 8}$ & $\mathbf{0 8}$ & $\mathbf{3 9}$ \\
\hline
\end{tabular}

Fonte: Tabela elaborada à partir dos dados da Coordenação de Aperfeiçoamento de Pessoal do Ensino Superior - Capes - BDTD

Analisando os dados apresentados nas tabelas, é possível notar o grande número de trabalhos no campo da educação envolvendo a temática corpo. Tal fato revela as possibilidades inesgotável de pesquisa deste objeto devido às suas metamorfoses resultantes de fatores econômicos, sociais, políticos e culturais no decorrer dos tempos. Após a seleção e organização dos trabalhos, produziu-se um gráfico que demonstra o número de trabalhos de nível de Mestrado e Doutorado. O referido gráfico é apresentado a seguir. 


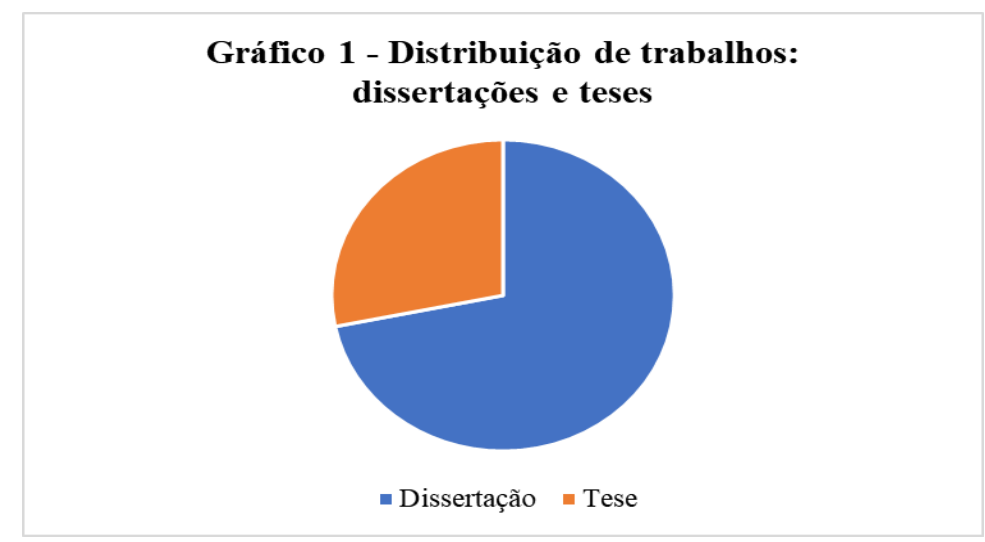

Fonte: Gráfico elaborado à partir dos dados coletados na BDTD Biblioteca Digital de Teses e Dissertações - Capes

Após isso, organizou-se um quadro com a síntese das dissertações e teses selecionadas na Biblioteca Digital de Teses e Dissertações da Capes (BDTD-Capes) por ano de publicação, conforme o quadro a seguir.

Quadro 1 - Teses e dissertações selecionadas na Biblioteca Digital de Teses e Dissertações da Capes - BDTD

\begin{tabular}{|c|c|c|}
\hline AUTOR/ANO & TÍTULO & NÍVEL \\
\hline $\begin{array}{l}\text { BACCIN, Adriana } \\
\text { Nolibos (2013) }\end{array}$ & $\begin{array}{l}\text { Corpo e cultura de movimento no teatro da } \\
\text { formação cultural: ainda Ulisses? }\end{array}$ & Mestrado \\
\hline $\begin{array}{l}\text { BATISTA, Alison } \\
\text { Pereira (2013) }\end{array}$ & $\begin{array}{c}\text { Conhecimentos sobre o corpo: uma } \\
\text { possibilidade de intervenção pedagógica nas } \\
\text { aulas de Educação Física no Ensino Médio }\end{array}$ & Mestrado \\
\hline $\begin{array}{l}\text { ARANTES, } \\
\text { Gabriela Villela } \\
\quad \text { (2013) }\end{array}$ & $\begin{array}{c}\text { A Educação Física em cena: olhares sobre o } \\
\text { Colégio Estadual de Minas Gerais (1956- } \\
\text { 1973) }\end{array}$ & Mestrado \\
\hline $\begin{array}{l}\text { TOFOLI, Heloisa } \\
\text { Helena (2013) }\end{array}$ & $\begin{array}{l}\text { Políticas públicas em educação: a presença do } \\
\text { corpo na educação brasileira - } 2000 \text { a } 2012\end{array}$ & Mestrado \\
\hline $\begin{array}{l}\text { ANGELO, Marina } \\
\text { Balastreire (2013) }\end{array}$ & $\begin{array}{l}\text { As práticas corporais no trabalho do professor } \\
\text { de arte: um estudo em Várzea Paulista/SP }\end{array}$ & Mestrado \\
\hline $\begin{array}{l}\text { JUNIOR, } \\
\text { Moaldecir Freire } \\
\text { (2013) }\end{array}$ & $\begin{array}{c}\text { Por uma educação dos sentidos: um diálogo } \\
\text { entre Merleau-Ponty e Ueshiba }\end{array}$ & Mestrado \\
\hline $\begin{array}{l}\text { SILVA, Priscilla } \\
\text { Stuart da (2013) }\end{array}$ & $\begin{array}{c}\text { Educação estética: corpo, experiência e } \\
\text { memória em Walter Benjamin }\end{array}$ & Mestrado \\
\hline
\end{tabular}




\begin{tabular}{ccc}
\hline SANTOS, & Por uma educação da sensibilidade: narrativa, \\
Verônica Valério & mito, memória e transcendência em Cinema \\
(2013) & Paradiso & Mestrado \\
\end{tabular}

$\begin{array}{ccc}\text { JUNIOR, Aurélio } & \text { O corpo na educação emancipatória da } \\ \text { Bona (2013) } & \text { sexualidade: uma análise das iniciativas no } & \text { Doutorado } \\ \text { Paraná (2008-2009) } & \end{array}$

\begin{tabular}{|c|c|c|}
\hline $\begin{array}{l}\text { ZAGO, Luiz } \\
\text { Felipe } \\
\text { (2013) }\end{array}$ & $\begin{array}{c}\text { Os meninos: corpo, gênero e sexualidade em e } \\
\text { através de um site de relacionamentos }\end{array}$ & Doutorado \\
\hline $\begin{array}{c}\text { FERREIRA, Luiz } \\
\text { Olavo Fonseca } \\
\text { (2013) }\end{array}$ & $\begin{array}{c}\text { O corpo em cena na educação de jovens e } \\
\text { adultos: a mobilização para a aprendizagem } \\
\text { na EJA por meio dos significados expressos } \\
\text { pela corporeidade de mulheres adultas }\end{array}$ & Doutorado \\
\hline $\begin{array}{c}\text { SILVA, Maria } \\
\text { Aparecida Alves da } \\
(2013)\end{array}$ & $\begin{array}{l}\text { Alforria pelo sensível: corporeidade da } \\
\text { criança e formação docente }\end{array}$ & Doutorado \\
\hline $\begin{array}{l}\text { SEHN, Carina } \\
(2014)\end{array}$ & $\begin{array}{c}\text { Um corpo performático para romper com a } \\
\text { representação }\end{array}$ & Mestrado \\
\hline
\end{tabular}

\begin{tabular}{cc}
\hline STROHER, & O trabalho com o corpo/aluno na Educação \\
Jonathan & Física escolar sob a óptica dos discentes do \\
(2014) & Curso de licenciatura em Educação Física da \\
& Unemat/Cáceres: um estudo de representações \\
sociais
\end{tabular}

\begin{tabular}{lcc}
\hline DINIZ, Luciene & A construção do sujeito encarnado na \\
Teixeira (2014) & experiência docente & Mestrado
\end{tabular}

\begin{tabular}{ccc}
\hline $\begin{array}{c}\text { ARAUJO, Márcia } \\
\text { Feijó de (2014) }\end{array}$ & Linguagem corporal, docência e teoria crítica & Mestrado \\
\hline $\begin{array}{c}\text { SANTOS, Maria } \\
\text { Valéria Rodrigues } \\
\text { dos (2014) }\end{array}$ & Uma professora de arte em trans-formação: & \\
& corpos e materialidades & Mestrado \\
MENDES, & Os corpos e os processos de docilização na & \\
Vanderlei da Silva & educação: uma leitura foucaultiana & Mestrado \\
$(\mathbf{2 0 1 4})$ & Corpo a dançar: entre educação e criação de & \\
\hline $\begin{array}{l}\text { FERRAZ, Wagner } \\
(2014)\end{array}$ & & corpos
\end{tabular}

$\begin{array}{cc}\text { SILVA, Aline } & \text { Currículo e diferença: cartografia de um } \\ \text { Ferraz da (2014) } & \text { corpo travesti }\end{array}$

\begin{tabular}{lcc}
\hline FISCHER, Deivis & Educação e sensibilidade: tensões e desafios & \\
Alexandre (2015) & & Mestrado \\
\hline $\begin{array}{c}\text { CHAVES, Silvane } \\
\text { Lopes (2015) }\end{array}$ & $\begin{array}{c}\text { Sobre corpos insolentes: corpo trans, um } \\
\text { ensaio estético da diferença sexual na } \\
\text { educação }\end{array}$ & Mestrado \\
\hline
\end{tabular}




\begin{tabular}{|c|c|c|}
\hline $\begin{array}{l}\text { SCHAEFER, } \\
\text { Katia de Souza e } \\
\text { Almeida Bizzo } \\
\text { (2015) }\end{array}$ & $\begin{array}{l}\text { O corpo como vontade de potência (em } \\
\text { experiências) na educação infantil e nos } \\
\text { primeiros anos do Ensino Fundamental }\end{array}$ & Doutorado \\
\hline $\begin{array}{l}\text { PANIZZI, Alan } \\
\text { David Evaristo } \\
\quad \text { (2016) }\end{array}$ & $\begin{array}{l}\text { Experimentações corporais como produtoras } \\
\text { de (re)existência frente à futilidade presente } \\
\text { na estética das práticas pedagógicas }\end{array}$ & Mestrado \\
\hline $\begin{array}{l}\text { VALGAS, Aline } \\
\text { Flávia (2016) }\end{array}$ & $\begin{array}{c}\text { A relação entre a educação do corpo no Brasil } \\
\text { da Primeira República e os contos de Lima } \\
\text { Barreto }\end{array}$ & Mestrado \\
\hline $\begin{array}{l}\text { SANTOS, } \\
\text { Anderson } \\
\text { Carvalho dos } \\
\text { (2016) }\end{array}$ & $\begin{array}{l}\text { Fortalecimento do corpo e educação dos } \\
\text { sentidos: as primeiras lições de Rousseau na } \\
\text { formação do Emílio Antônomo }\end{array}$ & Mestrado \\
\hline $\begin{array}{c}\text { PONTES, Bruno } \\
\text { (2016) }\end{array}$ & $\begin{array}{c}\text { “Eu sou essa! Eu sou esse!” Corpos, } \\
\text { perspectivas e minúcias teatrais na pequena } \\
\text { infância }\end{array}$ & Mestrado \\
\hline
\end{tabular}

\begin{tabular}{ccc}
\hline $\begin{array}{c}\text { DEMETRIO, } \\
\text { Rubia Vanessa } \\
\text { Vicente (2016) }\end{array}$ & $\begin{array}{c}\text { A dimensão corporal na relação educativa } \\
\text { com bebês: na perspectiva das professoras }\end{array}$ & Mestrado \\
\hline $\begin{array}{c}\text { COFFANI, } \\
\text { Márcia Cristina } \\
\text { Rodrigues da Silva } \\
\text { (2016) }\end{array}$ & $\begin{array}{c}\text { Onsino Médio: um estudo sobre suas práticas } \\
\text { Eedagógico-curriculares }\end{array}$ & Doutorado \\
& &
\end{tabular}

\begin{tabular}{ccc}
\hline MOREL, Márcia & A educação do corpo no Projeto Anisiano de & \\
(2016) & Educação & Doutorado
\end{tabular}

\begin{tabular}{|c|c|c|}
\hline $\begin{array}{l}\text { RANNIERY, } \\
\text { Thiago } \\
\text { (2016) }\end{array}$ & $\begin{array}{l}\text { Corpos feitos de plástico, pó e glitter: } \\
\text { currículos para dicções heterogêneas e } \\
\text { visibilidades improváveis }\end{array}$ & Doutorado \\
\hline
\end{tabular}

\begin{tabular}{ccc}
\hline SILVA, Bruna da & Reflexões sobre o corpo infantil nas práticas \\
(2017) & $\begin{array}{c}\text { educativas do } 1^{\circ} \text { Ano do Ensino Fundamental: } \\
\text { O lugar do movimento em pauta }\end{array}$ & Mestrado
\end{tabular}

\begin{tabular}{ccc}
\hline FILHO, Flavio de & $\begin{array}{c}\text { Educação do corpo na perspectiva de gênero: } \\
\text { Andrade Benini } \\
\text { (2017) }\end{array}$ & uma análise de projetos públicos de esporte e \\
lazer & Mestrado
\end{tabular}

\section{TOMAZETT,} Luciano de Castro (2017)
A marca no corpo: futebol, tatuagem e educação
Mestrado Corpo regulamentado, corpo rebelado: Atheneu Sergipense (1909-1911) Mestrado

$\begin{array}{ccc}\text { AMADO, Paula } & \text { Corpo regulamentado, corpo rebelado: } & \\ \text { Barreto Dória } & \text { Atheneu Sergipense (1909-1911) } & \text { Mestrado } \\ \text { (2017) } & \end{array}$




\begin{tabular}{ccc}
\hline $\begin{array}{c}\text { BARBOSA, } \\
\text { Pietrine Paiva } \\
\text { (2017) }\end{array}$ & $\begin{array}{c}\text { Professores de Educação Física formados em } \\
\text { instituiçães privadas e a problematização do } \\
\text { corpo }\end{array}$ & Mestrado \\
\hline $\begin{array}{c}\text { SANTOS, } \\
\begin{array}{c}\text { Weslaine Alline da } \\
\text { Silva Faria (2017) }\end{array}\end{array}$ & $\begin{array}{c}\text { Educação do corpo: um inventário de seus } \\
\text { temas, autores e recortes }\end{array}$ & Mestrado \\
\hline $\begin{array}{c}\text { MORAES, } \\
\text { Cláudia Emilia } \\
\text { Aguiar (2017) }\end{array}$ & $\begin{array}{c}\text { A educação do corpo à beira-mar: esporte e } \\
\text { modernidade na Ilha de Santa Catarina (1857- } \\
\text { 1932) }\end{array}$ & Doutorado \\
\hline $\begin{array}{c}\text { MARTINI, } \\
\text { Cristiane Oliveira } \\
\text { Pisani (2017) }\end{array}$ & $\begin{array}{c}\text { Regule-se, exercite-se, embeleze-se: } \\
\text { pedagogias para o corpo feminino pelo } \\
\text { discurso da Revista Alterosa (1939-1964) }\end{array}$ & Doutorado \\
\hline
\end{tabular}

Fonte: Quadro elaborado pelo pesquisador: organização das teses e dissertações selecionadas na Biblioteca Digital de Teses e Dissertações (BDTD) da Capes.

A fim de provocar uma maior contextualização, elaborou-se um outro quadro para facilitar a apresentação das sínteses dos referidos trabalhos selecionados. O referido quadro identifica e organiza os trabalhos por meio de alguns elementos: a) instituição à qual a pesquisa está vinculada; b) o título da pesquisa; c) o autor da pesquisa; d) o ano de publicação; e) um resumo sintético para situar o contexto da pesquisa selecionada. Este quadro encontra-se no Anexo I.

Após a sistematização das pesquisas, foi possível identificar o ponto nuclear das discussões, classificando-as em pesquisas que discutem a temática corpo sob o viés das seguintes expressões: a) dança; b) literatura; c) fisioterapia; d) teatro escolar; e) artes e a educação estética; f) formação docente; g) educação dos sentidos e sensibilidades; h) educação sexual e de gênero; i) educação física escolar; j) educação; k) educação do corpo. Apesar de todas as discussões pautarem-se no campo da educação, algumas pesquisas direcionam suas análises para áreas mais específicas. Este fato contribuiu para a realização desta classificação.

Em suma, as categorias educação e educação do corpo apresentam muitas proximidades. O mesmo acontece com as categorias teatro escolar, dança, artes e educação estética. No entanto, o tratamento dado ao conceito de corpo nessas discussões se difere bastante. Desse modo, pelo tratamento dado às pesquisas, criou-se a necessidade de novas categorias de classificação. Assim, o gráfico abaixo demonstra, em quantidade, a classificação das teses e dissertações selecionadas: 


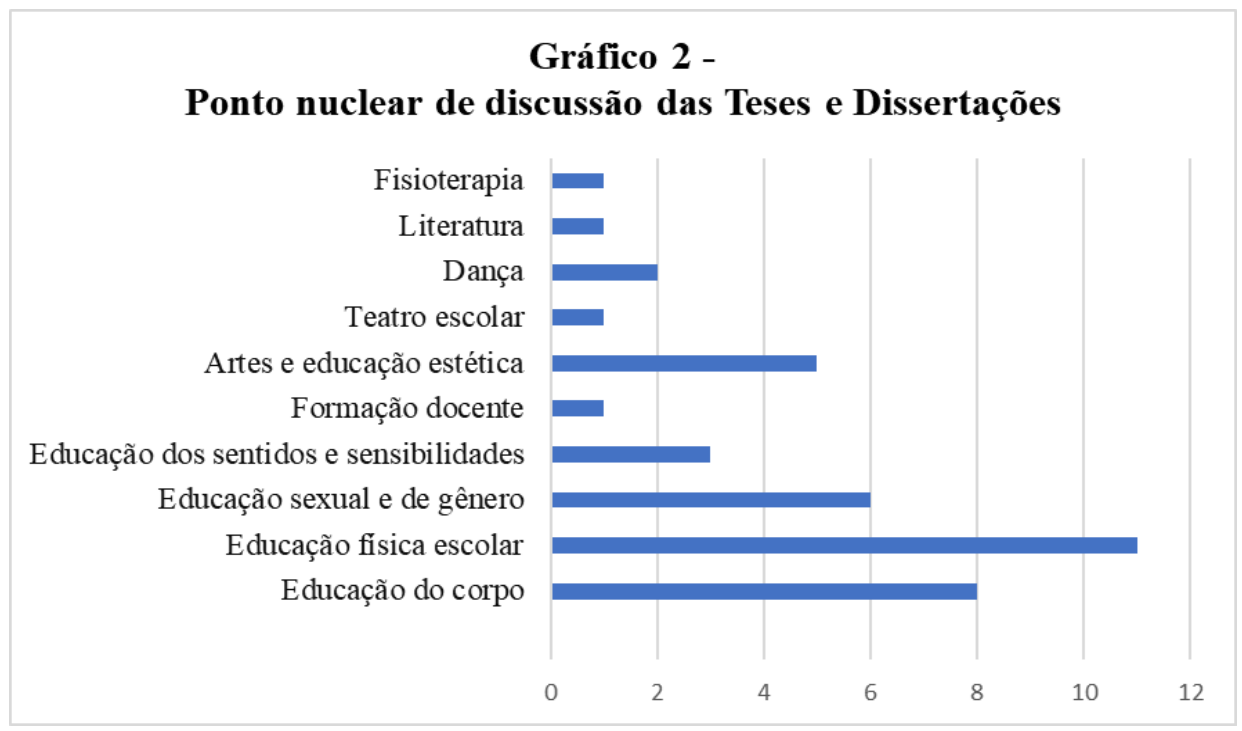

Fonte: Gráfico elaborado à partir dos dados coletados na BDTD Biblioteca Digital de Teses e Dissertações - Capes

Por intermédio do gráfico acima, observa-se uma predominância de trabalhos com foco de discussão na área da educação física escolar. Os dados revelam a evidente necessidade dessa área do conhecimento humano de discutir constantemente o corpo em sua relação com a educação. De modo geral, os trabalhos classificados nesta categoria, por exemplo, demonstram preocupações com a biologia do corpo, o seu funcionamento fisiológico, a cultura corporal de movimento, a pedagogia dos esportes na formação de corpos saudáveis, a educação e a saúde corporal diante dos meios midiáticos, a formação de professores na prática corporal, dentre outras. Enquadraram-se nessa categoria os trabalhos de Baccin (2013), Batista (2013), Arantes (2013), Stroher (2014), Coffani (2016), Morel (2016), Filho (2017), Tomazett (2017), Barbosa (2017), Santos (2017) e Moraes (2017).

Ainda conforme o gráfico 2, a categoria educação sexual e de gênero ocupou lugar de destaque. Essa categoria marca uma tendência crescente de trabalhos que buscam compreender o corpo por meio das questões de gênero, sexualidades e comportamentos sexuais. Atualmente, muitos congressos científicos da área da educação têm criado eixos temáticos de discussão para essas questões. Para se ter uma ideia, ao visitar a página virtual da ANPED - Associação Nacional de Pós-Graduação e Pesquisa em Educação, na aba eventos, foi possível identificar oito eventos com eixos temáticos voltados para a educação sexual e de gênero que ocorreram no ano de 2018. Esquematizados por ordem de aparição na referida página, os eventos são: 
a) VI Seminário da Educação Brasileira, realizado na cidade de Campinas-SP pela Universidade de Campinas;

b) V Colóquio Internacional Corpo e Cultura do Movimento, realizado na cidade de Natal-RN pela Universidade Federal do Rio Grande do Norte;

c) V Colóquio de Estudos, Pesquisas e Intervenções em Currículo e Formação, realizado na cidade de Salvador-BA pela Universidade Federal da Bahia;

d) V Seminário Discente PPGE-UFF, realizado na cidade de Niterói-RJ pela Universidade Federal Fluminense;

e) X Congresso Brasileiro de Pesquisadores/as Negros/as, realizado na cidade de Uberlândia pela Universidade Federal de Uberlândia;

f) II Seminário Estado, Trabalho, Educação e Desenvolvimento, realizado na cidade de Niterói-RJ pela Universidade Federal Fluminense;

g) IX Colóquio Internacional de Filosofia e Educação, realizado na cidade do Rio de Janeiro-RJ pela Universidade do Estado do Rio de Janeiro;

h) VII Seminário Corpo, Gênero e Sexualidade: resistências e ocupa(ações) nos espaços de educação, realizado na cidade de Rio Grande-RS pela Universidade Federal do Rio Grande.

De modo geral, são pesquisas, debates e discussões necessárias que corroboram para pensar a educação do mundo atual, marcada pela luta, resistência e reconhecimento de pessoas e grupos minoritários. É importante ressaltar também a natureza dos trabalhos selecionados e classificados na categoria educação sexual e de gênero. São trabalhos que discorrem sobre o corpo nas mais diferentes condições de gênero, a luta pela aceitação dos corpos não padronizados, as gesticulações como afirmações de corpos não heterossexuais, a relação dos escolares na formação de uma identidade de gênero, o empoderamento feminino e homossexual, dentre outras questões. Enquadramse nessa categoria os trabalhos de Junior (2013), Zago (2013), Silva (2014), Chaves (2015), Ranniery (2016) e Martini (2017).

Os trabalhos classificados na categoria artes e educação estética discutem o corpo com a pretensão de entender o desenvolvimento da corporeidade, a pedagogia do corpo, a formação de saberes sensíveis, a consciência corporal, dentre outros. Em sua maioria, são pesquisas que retratam diferentes experiências sobre a apreciação estética e as performances como um caminho para se pensar a educação do corpo no contexto 
escolar. Enquadram-se nessa categoria os trabalhos de Angelo (2013), Silva (2013), Santos (2013), Sehn (2014) e Santos (2014).

As pesquisas de Silva (2013), Ferreira (2013), Mendes (2014), Schaefer (2015), Demetrio (2016), Silva (2017) e Amado (2017) foram classificados na categoria educação do corpo. São trabalhos preocupados em discutir a punição corporal escolar, a disciplina dos corpos na escola, a dimensão corporal do sujeito na escola, dentre outros. De modo geral, as pesquisas desta categoria somam inúmeras contribuições para o entendimento da cultura corporal escolar e dos modos pelos quais o corpo é disciplinado e punido pelas instituições de ensino. Aparecem também nas discussões dessas pesquisas a resistência dos corpos engessados, o corpo infantil escolarizado, a história e a antropologia do corpo.

A educação dos sentidos e sensibilidades é uma outra categoria que contempla as pesquisas de Fischer (2015), Panizzi (2016) e Santos (2016). São discutidos nesses trabalhos a questão da sensibilidade na educação, as experimentações corporais e o refinamento dos sentidos. Na categoria dança, Araújo (2014) e Ferraz (2014) desenvolveram pesquisas destinadas a discutir os problemas pertencentes a criação e a expressão corporal. São manifestadas em um contexto artístico, porém pautam-se no modo pelo qual o corpo desenvolve as potencialidades de movimentação e criação artísticas.

Por revelar compreensões acerca da experiência pedagógica corporal por meio do teatro escolar, a pesquisa de Pontes (2016) foi classificada na categoria teatro escolar. Trata-se de uma pesquisa realizada em uma escola pública da cidade de Belo Horizonte - MG e que demonstra como o teatro pode auxiliar as crianças em idade escolar a perceberem os seus corpos.

Valgas (2016) pesquisou os contos de Lima Barreto para anunciar as tensões corporais vivenciadas pelos sujeitos no período da Primeira República no Brasil. Por isso, por envolver a produção literária, este trabalho foi classificado na categoria literatura. A pesquisa de Diniz (2014), classificada na categoria formação docente, aborda a questão do corpo na docência. Ao indicar o modo pelo qual se dá a construção do corpo do professorado, o referido trabalho dialoga com a trajetória de vida do professor, as suas lutas e histórias.

Tófoli (2013) desenvolveu uma pesquisa a fim de investigar as políticas públicas em educação entre os anos de 2000 e 2012. Preocupada com o grande número 
de pacientes em idade escolar que frequentaram a clínica onde trabalha, vítimas de problemas posturais e de coluna, a pesquisadora lançou olhares para as políticas públicas educacionais pensadas para a acomodação dos corpos escolarizados. Por esse motivo, classificou-se esta pesquisa na categoria fisioterapia.

De modo geral, as pesquisas classificadas apresentam contribuições significativas para o campo da educação. Do mesmo modo, diferentes perspectivas teórico-metodológicas foram utilizadas. Em se tratado das bases teóricas dos trabalhos selecionados o Gráfico 3, a seguir, demonstra os autores mais utilizados nas discussões. Observando o referido gráfico, verifica-se a predominância de autores como Michel Foucault; Gilles Deleuze; David Le Breton; Guacira Louro; Judith Butler; Zygmunt Bauman; Miguel Arroyo; Walter Benjamin; Lev Vigotsky; Theodor Adorno; Karl Marx; dentre outros. É importante destacar a numerosidade elevada de pesquisas que utilizam Michel Foucault e David Le Breton como base teórica. De certo modo, os referidos autores possuem vasta produção científica envolvendo as questões do corpo, da sexualidade, das relações de poder e da construção social do corpo. Muitas de suas obras foram traduzidas para diferentes linguagens, fatos que corroboraram para a grande repercussão de suas ideias. Esses autores são encontrados nos trabalhos de Batista (2013); Angelo (2013); Santos (2013); Zago (2013); Ferreira (2013); Sehn (2014); Santos (2014); Mendes (2014); Ferraz (2014); Silva (2014); Chaves (2015); Coffani (2016); Tomazett (2017); Amado (2017); e Barbosa (2017).

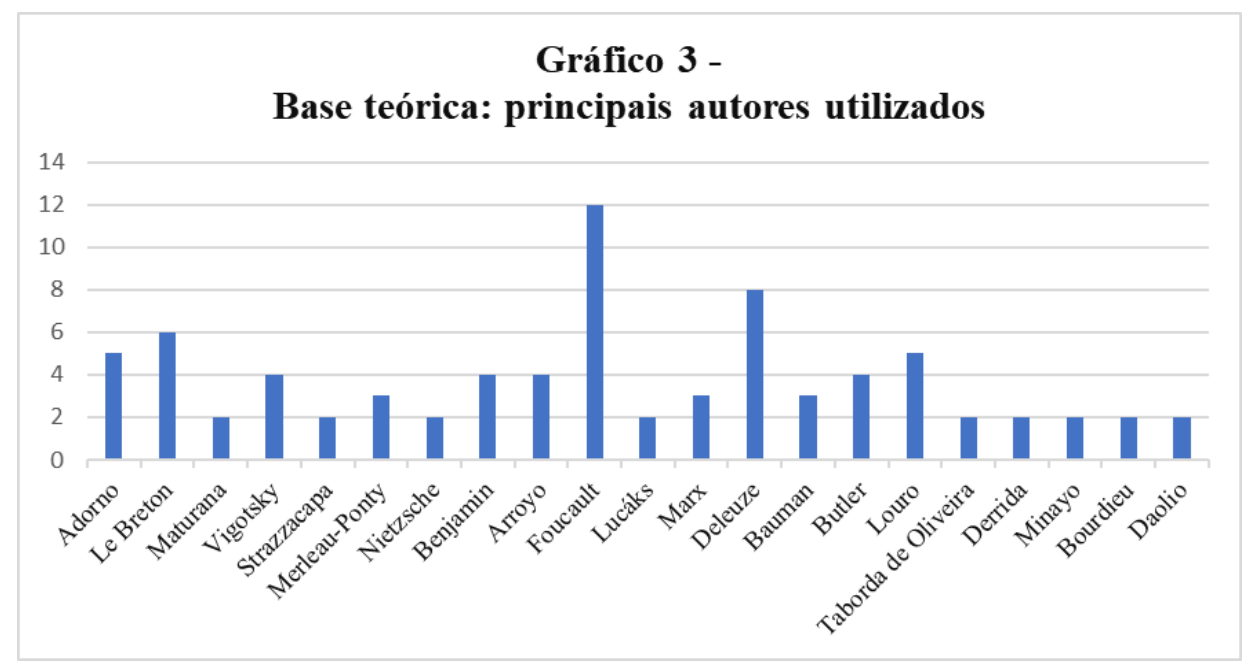

Fonte: Gráfico elaborado a partir dos dados coletados na BDTD Biblioteca Digital de Teses e Dissertações - Capes 
Utilizaram as ideias de Guacira Louro e Judith Butler como base teórica, em sua maioria, as pesquisas classificadas na categoria educação sexual e de gênero. As autoras anunciadas possuem uma larga produção acadêmica na área das questões de gênero e sexualidade e são encontradas nas pesquisas de Zago (2013); Ferreira (2013); Ranniery (2016); e Filho (2017).

Theodor Adorno e Walter Benjamin aparecem em maior número nos trabalhos classificados na categoria educação física e artes e educação estética. Englobam esses autores os trabalhos de Baccin (2013); Silva (2013); Santos (2013); Araújo (2014); Tomazett (2017); e Moraes (2017).

De modo geral, deve-se ressaltar a diversidade teórica das pesquisas selecionadas, bem como o ponto nuclear de discussão. Sem dúvida, são contribuições enriquecedoras que demonstram a necessidade constante de buscar novas compreensões para o corpo no contexto escolar. É preciso dizer que a conjuntura econômica, política e cultural a qual estamos inseridos é desafiadora e nos pressiona a realizar novas leituras, debates e pesquisas, uma vez que o corpo continua sendo lugar de mistério para as diferentes áreas do conhecimento humano.

De modo geral, este balanço, da produção acadêmica acerca do corpo no campo da educação, contribui significativamente para uma maior compreensão acerca do objeto investigado, dos referenciais teóricos e dos procedimentos metodológicos no trabalho de pesquisa com a temática corporal. 


\title{
CAPÍTULO II - EDUCAÇÃO, CORPO E SENSIBILIDADE NOS ESPAÇOS ESCOLARES: DIZERES E FAZERES
}

\author{
Todas as formas de criação artística, toda \\ especulação filosófica e estética, podem \\ ajudar a enriquecer nossa sensibilidade e \\ nossa inteligência - depende \\ do tempo e do lugar.
}

Augusto Boal.

A temática corpo está presente em diferentes áreas do conhecimento humano e, portanto, é concebido sob a ótica de diferentes abordagens teórico-metodológicas. Diante disso, este capítulo discute sobre a educação do corpo e das sensibilidades nos espaços escolares, tomado como referências diferentes autores do campo da educação. Ainda neste capítulo, analiso brevemente minhas práticas pedagógicas como professor de Geografia e Teatro em uma escola pública da região metropolitana de Goiânia-Go.

\section{1 - O corpo escolarizado: o que dizemos e o que fazemos}

As dúvidas e inquietações acerca do corpo na escola sempre acompanharam a minha trajetória docente. Comecei a questionar o corpo após as primeiras experiências docentes como professor de geografia em uma escola pública da região metropolitana de Goiânia-Go. Naquela época, as salas de aula do ensino fundamental eram lotadas e foram construídas com placas de concreto. O teto era baixo e possuía pouca ventilação, fato que contribuía para aumentar o calor e a inquietação das crianças. Era um incômodo. Todas as vezes que adentrava as salas de aula daquela escola eu repetia sempre as mesmas falas:

Vá para o seu lugar, sente-se e cale a boca!

Vou fazer um mapeamento da sala, separando os que conversam muito!

Copiem toda a tarefa do quadro sem reclamar! 
Fiquem quietos ou ficarão depois da aula!

Vocês têm meia hora para terminar de copiar a tarefa!

Só vai ao banheiro quem terminar a tarefa!

Quem não se comportar terá que trazer um responsável na próxima aula!

Se eu pegar aluno no corredor vou dar advertência!

Os próximos que conversarem terão que se entender com a coordenação!

Como se vê, eram rituais incansáveis de controle dos corpos acompanhados da realização de intermináveis tarefas e metas, na qual a liberdade de expressão se caracterizava como prêmio. Os estudantes, por sua vez, eram obrigados por mim e pelos demais professores da escola a permanecerem sentados durante quase todas as aulas. De modo geral, os estudantes recebiam uma educação transmitida por meio da fala docente e dos enormes textos transcritos na lousa para reprodução por parte dos alunos. Estes, por sua vez, passavam grande parte da aula cumprindo obrigações e metas de resolução de exercícios provenientes de cópias. Me tornei professor assim, reproduzindo uma prática de silenciamento do corpo.

Minha concepção de ensino era a de que o bom professor deveria manter o estudante imobilizado, calado e sem manifestar expressões. Essa concepção de ensino ainda tão presente nos estabelecimentos de ensino percorreu grande parte da minha carreira profissional. Mesmo sem me dar conta, eu e meus colegas de profissão praticávamos uma educação do corpo pois, conforme Strazzacappa (2001):

Toda educação é educação do corpo. A ausência de uma atividade corporal também é uma forma de educação: a educação para o não-movimento educação para a repressão. Em ambas as situações, a educação do corpo está acontecendo (STRAZZACAPPA, 2001, p.79).

Como se vê, o que nós praticávamos naquela escola era uma educação baseada em um modelo carcerário cuja finalidade era a domesticação dos corpos. Em nossa concepção, os alunos ruins eram aqueles dotados de comportamento inquieto, rebelde, atípico e não produtivo. Como norma, a vigilância reincidia sobre esses corpos. Os alunos bons eram os obedientes, compreensivos, dóceis e produtivos. Dez anos se passaram desde esse período. No entanto, pouca coisa mudou, pois, continuo presenciando na escola práticas de educação do corpo semelhantes à descrição acima. A inquietação corporal e a prática da educação do corpo para a obediência permanecem. Em um estudo realizado sobre o assunto, Farah afirma: 
Observados em aulas expositivas, os alunos não cessam de buscar ora uma posição mais confortável, ora um deslocamento nesse espaço. A inquietação corpórea pode nos indicar que o tempo de atenção dos alunos é inversamente proporcional à sua necessidade de movimentação. Podemos nos indagar: Quais seriam as modalidades didáticas utilizadas pelo professor? Quanto tempo é possível permanecer sentado e atendo a uma aula expositiva? Será que a "indisciplina" dos alunos de uma escola está pautada na quietude de seus corpos? [...] A indisciplina pode estar associada, muitas vezes, a determinados discursos do professorado, ao que se refere à inquietação corpórea dos alunos e à sua necessidade de movimentação (FARAH, 2010, p.407).

Farah (2010) profere questionamentos chamativos sobre como os docentes reconhecem o corpo indisciplinado na escola. Em minha prática pedagógica, por exemplo, essa necessidade de movimentação do corpo era tida como exagerada e necessitava ser diminuída. Sem dúvidas, era uma prática de educação do corpo normalizada, da qual o sucesso pedagógico advinha da coibição de movimentos dos alunos em sala de aula. Era como se o corpo fosse componente exclusivo das aulas de educação física, disciplina na qual o movimento e a atividade corporal são mais predominantes. De acordo com Silva e Weiss (2004):

O corpo está todo tempo presente na aprendizagem humana. E, apesar de
todos esses conhecimentos, comumente ainda se observam, nas escolas,
desde a primeira série, crianças sentadas uma atrás da outra, cabeças olhando
cabeças, corpos presos atrás das mesas, 'petrificados', olhares fixos no
caderno; quando alguns conversam, a professora pede silêncio. E o corpo
sofre. A partir da primeira série, as atividades corporais ficam limitadas e, na
maioria das vezes, reduzidas a movimentos repetitivos. Praticamente se anula
a forma construtiva com que o corpo atua nos processos de ensino e
aprendizagem. Parece que, na primeira série, os alunos são vistos como
meros robôs, onde o corpo deve estar aprisionado para que, assim, seja
adquirido o mais importante: o cumprimento do programa curricular da
disciplina (SILVA e WEISS, 2004, p.81).

Nas palavras de Silva e Weiss (2004), o corpo escolarizado sofre muito porque a tortura da quietude corporal e do silêncio ferem nossos princípios fisiológicos. Segundo as ciências biológicas e da saúde, nós somos seres preparados para o movimento, nós somos corpos em movimento. De modo geral, conforme Le Breton (2012), o nosso corpo assume um lugar privilegiado de contato com o mundo, porém é orientado a seguir procedimentos padrões de comportamento para aprender e para viver no mundo. Em outras palavras, nós somos seres construídos para o movimento, porém, muitas instâncias sociais trabalham para controlar nossos movimentos, de forma a atender determinados anseios sociais. 
De fato, nossa saúde depende de nossa predisposição para o movimento. Em várias pesquisas na área da medicina, por exemplo, os resultados indicam a necessidade de incrementar o movimento, a atividade física e os esportes como possibilidade para aumentar a nossa saúde física e psicológica. No entanto, poucos movimentos são permitidos dentro e fora das escolas. Correr no meio de um shopping center, por exemplo, pode caracterizar uma prática ilícita. De modo geral, em nossa sociedade, cada lugar e tempo possuem sistemas de permissões e negações de movimentos que são amparados em procedimentos pré-estabelecidos. São exemplos claros daquilo que Durkheim (1972) denominou de coerção social. ${ }^{1}$

Percebe-se, com isso, um interesse crescente de muitas instâncias sociais na negação do corpo, dos gestos e dos movimentos fora das normativas construídas. Na escola não é diferente. Há normativas predominantes que permitem ou proíbem os corpos dos sujeitos de se movimentarem e se expressarem. Os professores em sua maioria, por exemplo, condenam os movimentos acelerados realizados pelos estudantes nos corredores das escolas. O fato é que não aprendemos a pensar com o corpo e, consequentemente, não aprendemos a ensinar a pensar com o corpo. Sobre esse assunto, segundo o teatrólogo Augusto Boal (2009):

Pensar é sobretudo sentir, e que só a sensibilidade nos faz saber que existimos, mas afirmo que o ato de pensar com palavras tem início nas sensações e, sem elas, não existiria, embora delas se desprenda e se autonomize até à sua mais total abstração (BOAL, 2009, p. 27).

Quando me apropriei desse entendimento, coloquei em evidência a necessidade de repensar a educação do corpo promovida pela escola. Creio que é preciso considerar o corpo como sujeito central da aprendizagem escolar, visto que:

O corpo, o sentimento, a alegria, o desejo, a imaginação, as emoções, os movimentos, precisam estar presentes no cotidiano escolar para que as crianças possam aprender de forma integral, corporal, intelectual e prazerosa. $\mathrm{Se}$ as aulas estiverem fundamentadas nos canais proprioceptivos, visuais, auditivos e táteis, a aprendizagem acontece de forma eficiente e agradável. $\mathrm{O}$

\footnotetext{
1 "Desde os primeiros momentos de sua vida, forçamo-las a comer, a beber, a dormir em horários regulares, forçamo-las à limpeza, à calma, à obediência; mais tarde, forçamo-las para que aprendam a levar em conta outrem, a respeitar costumes, as conveniências, forçamo-las ao trabalho, etc., etc. Se essa coerção cessa de pouco a pouco a ser sentida, é que pouco a pouco ela dá origem a hábitos, a tendências internas que a tornam inútil, mas que só a substituem pelo fato de derivarem dela (DURKHEIM, 2007, p. 06).
} 
conhecimento adquirido pela criança vira 'vitamina', ganha um sentido novo e, como resultado, há a retenção do aprendizado. É importante ressaltar o papel do educador no desenvolvimento do esquema corporal, devendo proporcionar à criança atividades de teatro, música, dança, jogos, utilização de materiais lúdicos, pois preparam o terreno para um aprendizado posterior tendo como propósito o desenvolvimento integral e social do aluno. A falta do trabalho corporal no ambiente escolar poderá refletir em problemas de aprendizagem, de integração e emocionais e também na própria vida, tornando o indivíduo, muitas vezes, agressivo, retraído, frustrado, sem iniciativas próprias e inseguro para saber lidar com os desafios (SILVA e WEISS, 2004, p.81).

Nas circunstâncias apontadas pelos autores acima, é possível observar o quanto a escola carece de considerações acerca do corpo, da educação do corpo e da educação das sensibilidades. A meu ver, considerar o corpo na escola é ir além de procedimentos mecânicos, engessados e repetitivos de gestos e movimentos. Se nosso corpo é ação, devemos considerá-lo nos processos de ensino e aprendizagem escolar. Isso requer do professor a criação de condições para uma aprendizagem por meio do fazer, do envolvimento corporal e da experiência como um todo.

De modo geral, a aprendizagem é acompanhada de processos cognitivos, afetivos, motores e sociais. Não são componentes isolados, mas sim frutos de uma dialética constante. Em se tratando da cognição nos processos de ensino e aprendizagem, Pinto salienta:

\begin{abstract}
A aprendizagem é concebida em termos de aquisição de novas informações e a sua integração no conjunto de conhecimentos existentes. Aprender, porém, não se limita apenas à aquisição de novas informações, mas tem ainda por objetivo corrigir, aprofundar, alargar e reorganizar a nossa base de conhecimentos existentes. Neste contexto, a aprendizagem não é independente dos outros processos mentais de atenção, percepção, memória e raciocínio, sendo o conhecimento de que somos portadores o resultado da mediação mais ou menos coordenada dos vários processos cognitivos (PINTO, 2001, p.17).
\end{abstract}

Observa-se nas palavras do autor a relevância da cognição como fundamento do pensamento racional, componente importante para o desenvolvimento humano. Preocupada com a dimensão afetiva, Sarmento ressalta que a afetividade acompanha o ser humano durante toda a sua vida. De acordo com a autora,

a afetividade é a base sobre a qual se constrói o conhecimento racional. As crianças que possuem uma boa relação afetiva são seguras, tem interesse pelo mundo que as cerca, compreendem melhor a realidade e apresentam melhor desenvolvimento intelectual (SARMENTO, 2010, p.10). 
Quando a autora realiza essa afirmativa, ela corrobora para o entendimento de que a construção do conhecimento e, portanto, o desenvolvimento humano perpassa por uma sólida prática afetiva. Caso contrário, encontraremos percalços pelo caminho de construção do saber.

Kolyniack Filho (2002) trabalha acerca da motricidade enquanto uma das dimensões humanas da aprendizagem e assim a define:

Forma concreta de relação do ser humano com o mundo e com seus semelhantes, relação esta caracterizada por intencionalidade e significado, fruto de um processo evolutivo, cuja especificidade encontra-se nos processos semióticos da consciência, os quais, por sua vez, decorrem das relações recíprocas entre natureza e cultura - portanto, entre as heranças biológica e sócio-histórica. A motricidade refere-se, portanto, a sensações conscientes do ser humano em movimento intencional e significativo no espaço-tempo objetivo e representado, envolvendo percepção, memória, projeção, afetividade, emoção, raciocínio. Evidencia-se em diferentes formas de expressão - gestual, verbal, cênica, plástica, etc. A motricidade configurase como processo, cuja constituição envolve a construção do movimento intencional a partir do reflexo, da reação mediada por representações a partir da reação imediata, das ações planejadas a partir das simples respostas a estímulos externos, da criação de novas formas de interação a partir da reprodução de padrões aprendidos, da ação contextualizada na história portanto, relacionada ao passado vivido e ao futuro projetado - a partir da ação limitada às contingências presentes. Esse processo ocorre, de forma dialética, nos planos filogenético e ontogenético, expressando e compondo a totalidade das múltiplas e complexas determinações da contínua construção do homem (KOLYNIAK FILHO, 2002, p. 31).

Como se observa, o corpo humano é constituído de várias dimensões. De modo geral, a sensibilidade está associada a motricidade, cognição, afetividade e sociabilidade. Assim, educamos nossas percepções, sentidos, emoções e sensibilidades por meio das experiências corporais. Estas, por sua vez, não devem ser restritas apenas às aulas de educação física ou artes. O corpo está na escola e participa também das aulas de português, matemática, geografia, história e ciências.

Continuando a análise da minha performance docente, trabalhei durante maior parte da minha carreira no ensino fundamental e médio, assumindo nos últimos anos o ensino superior. No ensino médio, a dificuldade para desenvolver atividades com ênfase no corpo eram enormes. Isso não mudou muito. $O$ desânimo, a vergonha e o desinteresse tomam conta das expressões dos estudantes. Em muitos casos, movimentar-se é uma dificuldade advinda dos aparelhos controladores do corpo presentes na escola. Infelizmente, a uma cultura para o não-movimento predominam as práticas pedagógicas nas escolas. Nesses sistemas de ensino, a razão prevalece como o 
único caminho válido para a formação. Com esse entendimento, muitas escolas foram construídas sem levar em conta a necessidade do desenvolvimento de uma educação do corpo e das sensibilidades. Em algumas escolas, por exemplo, faltam espaços adequados para a prática de atividades corporais e de movimento. Conforme afirma Gaya (2006) sobre alguns sistemas de ensino:

\begin{abstract}
O corpo não vai à escola. Talvez vá, mas permanece sentado, disciplinado no silêncio e passividade de uma estátua de mármore. Ou, quem sabe, tal como marionete. Move-se por mecanismos articulados a partir de um conjunto de fios que se mantém sob o controle dos professores. Crianças e adolescentes imóveis nos bancos escolares a suportar uma ladainha sem fim. São letras e números que se combinam em textos de diversas disciplinas, que são dissecadas e devem penetrar pelos olhos, ouvidos de um corpo inerte. [...] Corpo aprisionado, imóvel e de costas para o mundo, vendo sombras na parede e tomando-as pela realidade, tal como na alegoria da caverna de Platão. Corpo disciplinado, ordenado, de forma que seus sentimentos, suas emoções não penetrem no mundo demasiado humano da suprema razão. Corpo desprezado. Corpo sem sentido. Razão sem corpo. Enfim, uma pedagogia que acaba por resumir sua anunciada complexidade ao res cogitans (GAYA, 2006, p.253).
\end{abstract}

Como se vê, muitas práticas escolares insistem em negar o corpo. Os procedimentos didático-pedagógicos e as estruturas físicas dos espaços escolares, em sua maioria, pouco contribuem para a composição de atividades corporais com finalidades voltadas para o desenvolvimento das emoções e das sensibilidades. Com esse preâmbulo, encontramo-nos diante de um grande desafio pois, apoiados na razão ${ }^{2}$, ignoramos o corpo e suas sensibilidades. Sobre esse assunto, segundo Santin (1997), a ordem racional surgiu como uma das possíveis formas de sensibilidade, o que contribuiu para o aparecimento de uma sensibilidade racionalizada. Segundo o autor:

A sensibilidade racionalizada, se assim posso me expressar, torna-se
controlada e controladora. A racionalidade é uma faixa da sensibilidade à
qual se impôs um domínio através de regras de manifestação. Assim não se
pode negar que o cientista não seja dotado de uma fina sensibilidade quando
realiza suas descobertas, entretanto, é uma sensibilidade treinada para
funcionar dentro de um determinado espectro. O homem das ciências foi
educado ou treinado a relacionar-se segundo os modelos científicos e a dirigir

${ }^{2}$ O filósofo René Descartes (1596-1650) deu início a uma grande problemática da Filosofia Moderna: a questão da relação entre mente e corpo. Para o referido pensador, o corpo e a mente compõem o corpo humano e são, por isso, uma unidade. $\mathrm{O}$ autor utiliza estudos e descrições anatômicas para desenvolver a sua tese. Nesse processo, elabora uma explicação cartesiana e utiliza o termo "espíritos animados" para desenvolver a ideia de alma, criada por Deus, para dar vida ao ser humano. De acordo com Borges e Vicentini (2013), Descartes contribui com os alicerces do modelo biomédico ao postular que mente e corpo são duas coisas distintas e separadas, ou seja, postular a divisão entre mente e corpo. Ainda segundo os autores, Descartes trata o problema mente-corpo em dois planos, o da divisão e o da união. 
sua ação segundo os princípios da tecnologia. É uma sensibilidade que se tornou autônoma porque funda-se sobre pesos e medidas e sobre ordens lógico-matemáticas e não sobre a liberdade de pensar de um sujeito humano. Haveria, assim, uma ordem racional independente do ser humano. Esta seria objetiva e determinista. É a ordem perseguida pela ciência, porque julgou-se que seria a ordem verdadeira do funcionamento da mente humana e, também, a ordem que sustenta o universo. Trata-se de uma lógica linear que possibilita acompanhar um movimento das causas aos efeitos e inversamente dos efeitos às causas. Foi assim que se constituiu a crença de que a verdadeira ordem humana é a ordem racional. E tudo o que o homem não se enquadra nas regras de uma lógica previsível estaria condenado às suspeitas dos fenômenos não confiáveis, porque volúveis, incontroláveis e imprevisíveis, como os sentimentos, as emoções, as paixões, produtos de uma sensibilidade não domesticável e não dominável (SANTIN, 1997, p.10).

Considerando as exposições de Santin (1997), deve-se ressaltar, no entanto, que a relação entre razão e emoção deve ser dialética e não polarizada. Assim, é preciso revelar o modo pelo qual o corpo e a sensibilidade são controlados pela escola. De modo geral, muitas instâncias sociais nos encaminham para um estado de corpo passivo, em espera e em conformidade com as grandes atrocidades. Segundo Surdi:

Cada vez mais se homogeniza o mundo. Minimizam-se as diferenças e uniformizam as semelhanças. Estamos nos distanciando de tudo e de todos e nesse processo nos perdemos como seres humanos. O humano que nos caracteriza está se afastando de nós. A sensibilidade no mundo da tecnologia e da ciência está desaparecendo, não há espaço para ela. Qual a utilidade da sensibilidade? A resposta a essa pergunta é fundamental para que a sensibilidade tenha um valor no mundo tecnocrático de hoje, mas isso é inviável. Assim, estamos perdendo o potencial para compreendermos a nós mesmos e, com isso, o poder de dar sentido à nossa vida (SURDI, 2018, p.70).

Ao observar as preocupações de Surdi (2018), em se tratando do menosprezo da sensibilidade pelo mundo dominado por técnicas, pode-se perceber o afloramento de um mundo contemporâneo marcado pela insensibilidade, solidão, isolamento social e aprisionamento. Sem sensibilidade perdemos nossa humanidade.

De todo modo, podemos afirmar que a sensibilidade é uma arma poderosa de luta contra o sistema e contra os poderosos controladores do mundo. O mundo das técnicas preza pelo controle silencioso das nossas experiências, de modo a dizimar novas sensibilidades. Este mundo prega uma sensibilidade voltada para ordem e obediência e por isso o teatro na escola se faz cada vez mais necessário. De acordo com Boal: 
Olhos nos permitem ver, mas também escondem; nossos ouvidos ensurdecem quando nos convém. São assim todos os nossos sentidos. O artista mostra o escondido, não o óbvio, e nos faz entender através dos sentidos - torna consciente o que estava em nós impregnado. (pag.56).

Nesse contexto, o teatro escolar torna-se uma necessidade devido a insistência social dos grupos dominantes em controlar nossos movimentos e sensibilidades. Nessa lógica, os nossos corpos devem ser submetidos a vigilâncias constantes e punições devem ser aplicadas para aqueles que não obedecerem às normativas estabelecidas. Nesse sistema pensado e organizado pelos grupos poderosos, os corpos opressores devem manter o controle sobre os corpos oprimidos. Essa é a lógica empregada pela sociedade globalizada para exercer o poder e dominar os corpos oprimidos.

Discorrendo sobre a tensão entre o mundo da razão, da racionalidade e a sensibilidade, Duarte Junior afirma:

\begin{abstract}
Não há porque a razão não se dar também no modo sensível, ou ter a sensibilidade como sua aliada, ainda que para certos procedimentos específicos da ciência ela deva se disciplinar a fim de cumprir os preceitos da objetividade. Tais coisas, no entanto, não parecem de fato incompatíveis, ainda que séculos de modernidade e os manuais de metodologia científica tentem nos convencer do contrário. Há, pois, que se dar ouvido às vozes e aos ensinamentos daqueles que, segundo já afirmado, vieram opondo, ao longo do tempo, suas opiniões ao racionalismo das correntes dominantes, na tentativa de também circunscrever, nos domínios da razão, a sapiência que nossos sentidos encerram (DUARTE JUNIOR, 2000, p.204).
\end{abstract}

Conforme Duarte Junior (2000), nossa responsabilidade na escola consiste em aproximar o mundo sensível e seus saberes do mundo científico. Nesse contexto, é preciso romper com a cultura da aprendizagem desvinculada de princípios de sensibilidade. É preciso questionar a educação do corpo desenvolvida na escola.

De fato, toda a constância construída pelo mundo da técnica visa impedir o desenvolvimento de um corpo sensível munido de autonomia de pensamento e de ação. Um corpo sensível, nesses moldes, representa uma ameaça ao sistema arquitetado de poderes e privilégios dos grupos dominantes. Segundo Boal (2009), é preciso "mostrar como os opressores usam os canais estéticos para intensificar a opressão através da docilidade obediente dos oprimidos; e como a contestação e a resposta são necessárias" (BOAL, 2009, p.54).

Entendida dessa forma, a sensibilidade é uma arma perigosa. É perigosa porque é contato, é presença, é estar junto, é o sentir, é o sentir-se com o outro, é a aliança, é a 
união, é a identidade, é a luta, é a resistência. O mundo das técnicas, por exemplo, abomina essas ideias porque prega o sentimento da individualidade, da concorrência e da segregação. Desse modo, um corpo sensível representa o enfrentamento porque não é capaz de suportar as mazelas deste mundo. Assim, um corpo sensível é um corpo disposto a reconhecer a sua liberdade e humanidade para pensar e agir. Conforme Surdi (2018):

\begin{abstract}
A sensibilidade fornece o sentido do corpo que, por sua vez, possibilita viver e perceber o mundo de várias maneiras. A sensibilidade nos dá a capacidade de inventar e criar; e isso nos credencia como seres diferentes, que percebem o mundo de modo diverso. Ela se liga aos detalhes significativos que, para muitas pessoas, passam despercebidos. Assim, ela se torna um fundamento que nos diferencia como seres únicos e livres, com nossas individualidades e singularidades (SURDI, 2018, p.61).
\end{abstract}

Ao realizar essas afirmações, Surdi (2018) chama a atenção para a importância de a escola, enquanto instituição formadora, trabalhar a sensibilidade nas suas diversas atividades didático-pedagógicas. Intencionada nessas ideias, a escola possibilitará aos estudantes o desenvolvimento de capacidades motoras e cognitivas necessárias para o despertar das individualidades e singularidades próprias de cada sujeito. Nesse sentido, é preciso reafirmar a nossa condição corporal de existência, pois, nosso corpo possui um modo próprio e particular de se fazer corpo, de se fazer humano. Com isso, pretende-se afirmar que todos nós somos portadores de saberes sensíveis com possibilidades de ampliação de nossos repertórios. Porém, como mencionado, o caminho é longo e demanda o rompimento de paradigmas culturais dominantes. Dessa maneira,

\footnotetext{
O que se visa, de fato, é um romper dos limites entre as formas parciais de conhecimento para a criação de saberes mais abrangentes e integrados, nos quais a razão possa exercer-se de maneira menos parcial e restrita. E o que se vem discutindo, inclusive, é a necessidade de nessa ampliação do conhecimento contemplar-se também o saber sensível, a necessidade de uma constante interação entre os dados da razão e os da sensibilidade, o que implicaria numa atuação mais inteira da consciência humana (DUARTE JUNIOR, 2000, p.207).
}

É um desafio e uma necessidade porque nossos sentidos e sensibilidades estão sendo diminuídos e limitados. O mundo das técnicas e do trabalho não admite emoções e sentimentos em seus processos de produção porque há uma técnica racionalizada em operação, não sobrando até então espaços para a sensibilidade. No entanto, observa-se o aparecimento da sensibilidade com maior predominância nos mecanismos de indução ao 
consumo. A publicidade faz emergir como fábula a nossa sensibilidade. É uma sensibilidade controlada para o mercado, para o consumo e para a dominação. Sobre esse assunto, envolvendo o teatro, Boal (2009) ressalta:

O teatro, como algumas outras artes, é movimento. Movimento tem sentido e direção. O sentido é a estrada por onde se pode andar em duas direções; a direção é o caminho escolhido. Seja qual for o caminho e a estrada, o teatro tal como vem sendo praticado pelas classes dominantes, como forma de convencimento compulsivo -, mais que outras artes, imobiliza os espectadores na contemplação. Imobilizados, tornam-se vulneráveis. Vulneráveis, estão prontos a aceitar como seus as emoções e os pensamentos dos personagens e suas escolhas (BOAL, 2009, p.107).

Em concordância com as ideias de Boal (2009), pode-se dizer que as classes dominantes controlam nossos corpos, movimentos, expressões e sensibilidades. Nesse contexto, ou a escola assume uma condição de educação do corpo para as sensibilidades autônomas ou continuaremos a assistir atos de desumanidades cada vez com maior frequência. Sobre esse assunto, Sardi (2018) apresenta algumas considerações pertinentes. De acordo com o autor:

Nossos sentidos estão cada vez menos educados e atentos ao que é essencial no mundo. Não percebemos mais os ricos detalhes que poderiam trazer felicidade e alegria às nossas vidas. Estamos condicionados ao tempo e ao espaço que são determinados pela funcionalidade moderna. Nossa capacidade tátil também enfrenta enormes barreiras pela insensibilidade proporcionada pelo mundo moderno. O toque, sempre que possível, é evitado, como algo impuro e sujo. Isso acontece principalmente na ocorrência de certas doenças, como a gripe tipo A, uma das doenças surgidas no decorrer das transformações sociais impostas pelo processo industrialista. $\mathrm{O}$ toque, como possibilidade sensível de sentir os prazeres táteis do mundo, é negado a nós, e as crianças são quem mais sofrem com isso. Nossas crianças não possuem mais ambientes que favoreçam o toque ou o contato corporal com as inúmeras variações e diferenças que o mundo nos proporciona, e nem mesmo são estimuladas a isso. Experiências como subir numa árvore, brincar na terra e na lama, colher frutos em um pomar, andar descalço e confeccionar brinquedos com materiais variados como latas, elásticos, papéis, barbantes, bambus etc., praticamente foram extintas da vida de muitas crianças que vivem nas cidades, ou mesmo no campo. São raras as escolas que ainda mantêm essas experiências sensíveis, pois elas não são mais aprovadas pelos pais porque eles não gostam que seus filhos cheguem sujos em casa e porque criticam essas atividades por não serem produtivas, não possibilitam a aprendizagem (instrumental) e, assim, não servem para nada. Desta forma, podemos dizer que essas importantes experiências sensíveis não auxiliam (como querem os pais e a escola) a criança a se tornar um ser produtivo e pragmático, filho do capitalismo e escravo do trabalho. No entanto, tais experiências contribuem para que a criança seja cada vez mais humana, sensível e mais feliz. As experiências tratam a criança como criança, no seu tempo e no seu espaço, levando em consideração o aqui e o agora e não apenas o seu futuro, como se ela fosse um adulto em miniatura (SURDI, 2018, p.96). 
Ao tecer os argumentos acima, Surdi (2018) contribui para reforçar a necessidade de provocar a aprendizagem escolar para uma outra concepção de educação do corpo. Uma educação que considere o corpo como o centro do processo de ensino e aprendizagem. A escola ao tomar o corpo como o centro de todo o processo educacional pode dar outros sentidos e significados aos conteúdos ensinados. Possivelmente, ao considerar o corpo nas diferentes atividades escolares e no melhor aproveitamento dos espaços físicos, poderíamos presenciar na escola novas descobertas, aprendizagens múltiplas, a promoção da alteridade, o despertar de novas emoções, a solidariedade, o respeito às particularidades de cada sujeito, o reconhecimento de si e do outro, o resgate da autoestima, a responsabilidade, dentre outras questões. No entanto, conforme aponta Duarte Junior (2000):

\begin{abstract}
O saber sensível mostra-se, primordialmente, um ato prazeroso e, como tal, encarado com suspeição por todo aquele que pensa a educação como uma atividade estoica, dura, áspera, cinzenta e desprazerosa. "O dever antes do prazer", reza antigo preceito, na certeza de que o dever (de aprender) há de ser incompatível com qualquer fruição prazenteira das coisas do mundo. Sensibilidade e objetividade, por conseguinte, só podem mesmo ser excludentes entre si desde este ponto de vista. Neste sentido, a educação como atividade científica (e, portanto, isenta de sentimentos e valores) vem, há muito, servindo de ideal para um sem-número de educadores e cursos de formação de professores, na esperança de que tal atitude, pretensamente rigorosa no cumprimento de cânones objetivos, possa redundar em pessoas dotadas de um conhecimento exato e preciso acerca do mundo, bem como de um padrão de pensamento que não se deixaria enganar pela "ilusão dos sentidos". Porém, a vida humana, em seu desenrolar cotidiano, carrega bem pouco de rigoroso ou de científico. Ela é feita substancialmente de impressões e estimulações sensórias, às quais tentamos colocar alguma ordem através do pensamento conceitual (DUARTE JUNIOR, 2000, p.203).
\end{abstract}

Essa, de maneira geral, é a leitura que nos interessa nesta pesquisa, pois, se o corpo está na escola todos os dias não devemos silenciá-lo, tampouco ignorá-lo. Pelo contrário, nosso compromisso transcorre pela necessidade de mostrar que temos muito a aprender com o movimento, com a expressão e com as experiências corporais dos sujeitos. Se a aprendizagem deriva da capacidade sensorial de captar a realidade, é preciso refletir acerca daquilo que os corpos-sujeitos fazem dessas percepções e apreensões dessa realidade.

Nesse processo de conhecer, sensibilidades foram despertadas e precisam ser trabalhadas para se alcançar o pleno desenvolvimento motor e cognitivo. Demonstra-se, com isso, a necessidade de uma escola aberta a pensar com o corpo e sobre o corpo. 
Com relação a isso, o autor apresenta contribuições significativas acerca dos sentidos das sensibilidades, pois nós, o povo brasileiro, somos portadores de sabedorias sensíveis criadas a partir de nossa liberdade corpórea. Por esse motivo, segundo o autor, somos um povo com necessidades de uma educação provocadora de novas sensibilidades, saberes e conhecimentos. Nas palavras do autor:

\begin{abstract}
Sabedoria da vida e lição de coisas presentes na alma de um povo resistente que se espalha pelos rincões deste país continental, sabedoria a qual autores como Maffesoli e Boaventura do Amaral, que viemos citando, valorizam e reputam importância hoje na construção de novos conhecimentos, afastando o caráter pejorativo que sempre se emprestou à sua denominação de "senso comum". Sem esquecermos as reflexões apaixonadas empreendidas por Darcy Ribeiro acerca de nossas peculiaridades enquanto povo, povo dotado principalmente de uma sensibilidade corporal acurada que muito bem se traduz no futebol, em ritmos e danças como o samba, bem como na magistral música que, longe das imposições mercantis da mídia, segue sendo produzida por aqui. Neste sentido e para se empregar uma palavra já antiga (e ainda não "dicionarizada"), nossa malemolência, nossa ginga - este termo tão brasileiro - precisam ser valorizadas e servir de ponto de partida para a educação do sensível que se quer ver mais estimulada e disseminada entre os promotores das várias modalidades de ensino entre nós, sejam ou não oficiais. Não é, portanto, sem motivo que projetos educacionais conduzidos por grupos independentes ligados a movimentos musicais populares - como é o caso, dentre muitos, do Axé e do Timbalada, em Salvador, ou o Bate Late, em Campinas - venham apresentando bons resultados e recebendo elogios de entidades constituídas em prol do verdadeiro desenvolvimento humano. Nossa corporeidade, assumida assim de um jeito "solto" desde tenra idade (e que acaba sendo bastante bloqueada pelo racionalismo cerebral de nossa educação formalista) parece ser, por conseguinte, um sólido patrimônio com o qual se pode contar e do qual se deve partir para uma prática educacional voltada bem mais para a sabedoria (de vida) que o mero conhecimento especializado e desvinculado das atividades cotidianas (DUARTE JUNIOR, 2000, p.2015).
\end{abstract}

$\mathrm{Na}$ verdade, ao assumir essas ideias, estamos apostando em uma educação do corpo cuja finalidade esteja assentada em aumentar a capacidade de ação e experiências dos estudantes, de modo a encaminhar mudanças nesta sociedade carregada de tensões, contrastes e incertezas. Se aceitarmos a ideia de que a escola tem parcelas de responsabilidade na formação desses sujeitos, um primeiro caminho seria buscar o conhecimento da organização didático-pedagógica das escolas. Sobre esse assunto, Gaya (2006) coloca:

Nenhum sistema educativo, nenhuma pedagogia pode cumprir integralmente sua tarefa de deixar do lado de fora dos muros escolares o corpo. Se a educação física e a educação artística fossem disciplinas centrais nos programas escolares, então, provavelmente, teríamos uma pedagogia a tratar do corpo sensível, corpo expressivo, corpo esportivo (GAYA, 2006, p.252). 
Como se observa, é um caminho longo que se inicia na análise da estrutura física e se estende aos sistemas de controle do corpo e das sensibilidades adotado pela escola. A educação, nesse processo, cumpre um papel fundamental na formação de novas sensibilidades. Agora, diante do mundo das técnicas, se a filosofia da escola estiver assentada na promoção da liberdade humana, ela se tornará um lugar de solução de conflitos, de debate e de transformação porque terá que lidar com o rompimento das normativas estabelecidas e naturalizadas. Caso contrário, será sempre uma educação prisioneira da razão humana, acostumada a seguir normativas de comportamento, pensamento e ação. 


\title{
CAPÍTULO III - O CORPO NA ESCOLA: RUPTURAS E CONTINUIDADES
}

\author{
O mundo é como é, não como \\ gostaríamos que fosse: é preciso \\ mudá-lo para que seja!
}

Augusto Boal.

No capítulo anterior, dialogamos com diferentes autores da educação do corpo para afirmar que toda prática pedagógica é acompanhada de uma educação do corpo. Também debatemos sobre a importância da educação do corpo para o despertar de novas sensibilidades. Nesse sentido, este capítulo analisa a estrutura física de quatro escolas públicas estaduais localizadas na região central da cidade de Aparecida de Goiânia-Go, de modo a discutir os dados fotográficos coletados durante a observação.

\section{1 - O campo de observação}

Conforme mencionado no segundo capítulo deste trabalho, minha trajetória docente se desenrolou em escolas públicas da Rede Estadual de Ensino da região central da cidade de Aparecida de Goiânia-Go. Em decorrência disso, surgiu o interesse em investigar a educação do corpo praticada por essas escolas. Em suma, seis escolas estaduais localizam-se na região central da cidade de Aparecida de Goiânia-Go. Primeiramente, a finalidade das visitas consistiu em conhecer a estrutura e a organização dos espaços internos. Notadamente, em duas escolas, as diretoras julgaram a visita inapropriada e arriscada às suas gestões. Por conta disso, em primeira instância, as investigações foram realizadas em quatro escolas. A fim de nomeá-las, cada escola recebeu o nome de um dramaturgo brasileiro. A escolha se deu como forma de homenagem a alguns nomes importantes da literatura dramatúrgica do teatro brasileiro. 
Portanto, a primeira escola foi nomeada de Escola Martins Pena ${ }^{3}$; a segunda de Escola Nelson Rodrigues ${ }^{4}$; a terceira de Escola Maria Clara Machado ${ }^{5}$; e a quarta de Escola Ariano Suassuna ${ }^{6}$.

Primeiramente, nestas quatro escolas, realizamos um mapeamento fotográfico da estrutura física, dos espaços destinados às práticas corporais e observamos algumas situações didáticas de aprendizagem. Após a primeira visita, três das cinco escolas optaram por interromper as nossas investigações. Diversas alegações foram apresentadas, predominando o medo de retaliações advindas da secretaria de educação. Assim, concentramos nossas observações na Escola Nelson Rodrigues, unidade de ensino onde trabalho como professor de educação física e teatro. Dessa maneira, as observações prevalecem sobre a Escola Nelson Rodrigues. Assim, este capítulo analisa primeiramente a estrutura das cinco escolas visitadas. Em seguida, desvela o modo pelo qual a Escola Nelson Rodrigues considera e educa os corpos que ela recebe todos os dias.

\section{2 - Os muros escolares}

O primeiro contato dos estudantes com a escola acontece por meio da percepção visual. É uma experiência corporal manifestada de imediato na calçada de acesso à escola. Os muros não revelam apenas o nome da escola, mas também a sua

\footnotetext{
${ }^{3}$ Martins Pena ((1815-1848) - Considerado o pai do teatro de costumes no Brasil, Martins Pena escreveu várias comédias de costume das quais podemos destacar ' $\mathrm{O}$ juiz de paz na roça' (1842); 'O diletante' (1847); 'O noviço' (1853); dentre outras.

${ }^{4}$ Nelson Rodrigues (1912-1980) - Apontado como um dos maiores dramaturgos brasileiros do século XX. Escreveu inúmeras peças de características psicológicas, míticas e tragédias cariocas, como por exemplo 'A mulher sem pecados' (1941); 'Vestido de noiva' (1943); 'Senhora dos afogados' (1947); 'A falecida' (1953); 'O beijo no asfalto' (1960); dentre outras.

${ }^{5}$ Maria Clara Machado (1921-2001) - Filha do escritor Aníbal Machado, Maria Clara Machado escreveu inúmeras peças teatrais voltadas para o público infantil. Depois de estudar teatro em Paris, a referida dramaturga retornou ao Brasil e abriu uma escola de teatro no Rio de Janeiro denominada 'O Tablado'. Suas principais peças são 'Pluft, o fantasminha' (1955); 'O cavalinho azul' (1960); 'A menina e o vento' (1963); 'O gato de botas' (1987); dentre outras.

${ }^{6}$ Ariano Suassuna (1927-2014) - Em parceria com Herminio Borba Filho, Ariano Suassuna fundou o Teatro do Estudante em Pernambuco e, mais tarde, o Teatro Popular do Nordeste. Muitas de suas peças foram exaustivamente encenadas por diferentes grupos de teatro do país, além de adaptações para a televisão e cinema. De sua vasta produção, podemos citar 'Auto da compadecida' (1955); "O santo e a porca' (1957); 'A pena e a lei' (1959); 'Farsa da boa preguiça' (1960); dentre outras.
} 
poética visual. A precariedade na conservação de um muro escolar pode, por exemplo, anunciar um pouco do seu público, dos seus sistemas de organização e das necessidades básicas de infraestrutura. No caso das escolas públicas, há ainda uma insistência política de muitos governantes quanto à padrões de cores para as escolas. Muitas vezes, essas cores estão relacionadas a partidos políticos ou programas de governo.

Nesse contexto, é preciso salientar que a cores revelam simbologias e, portanto, podem anunciar modelos de comportamento corporal. As cores e fachadas das escolas despertam, num primeiro momento, sentimentos de estranhamento, pertencimento, afirmação ou negação. Uma escola arrojada pode, por exemplo, despertar a formação de uma identidade, um sentimento de pertencimento. Quando ocorre um estranhamento carregado de uma negação, estes sujeitos imprimem suas marcas como forma de serem vistos nestes lugares. Palavras, frases, siglas e recados são estampados nos muros e paredes das salas de aula, de modo a representar o sentimento de pertencimento desses sujeitos com a instituição de ensino.

Ao realizar o registro fotográfico da estrutura de algumas escolas públicas Rede Estadual de Ensino da região central da cidade de Aparecida de Goiânia-Go encontramos alguns elementos marcantes e que podem nos dar pistas para desvelar o corpo escolarizado na sua relação com o espaço físico. Das quatro escolas visitadas, duas chamaram muito a atenção devido as suas fachadas e portões de entrada.

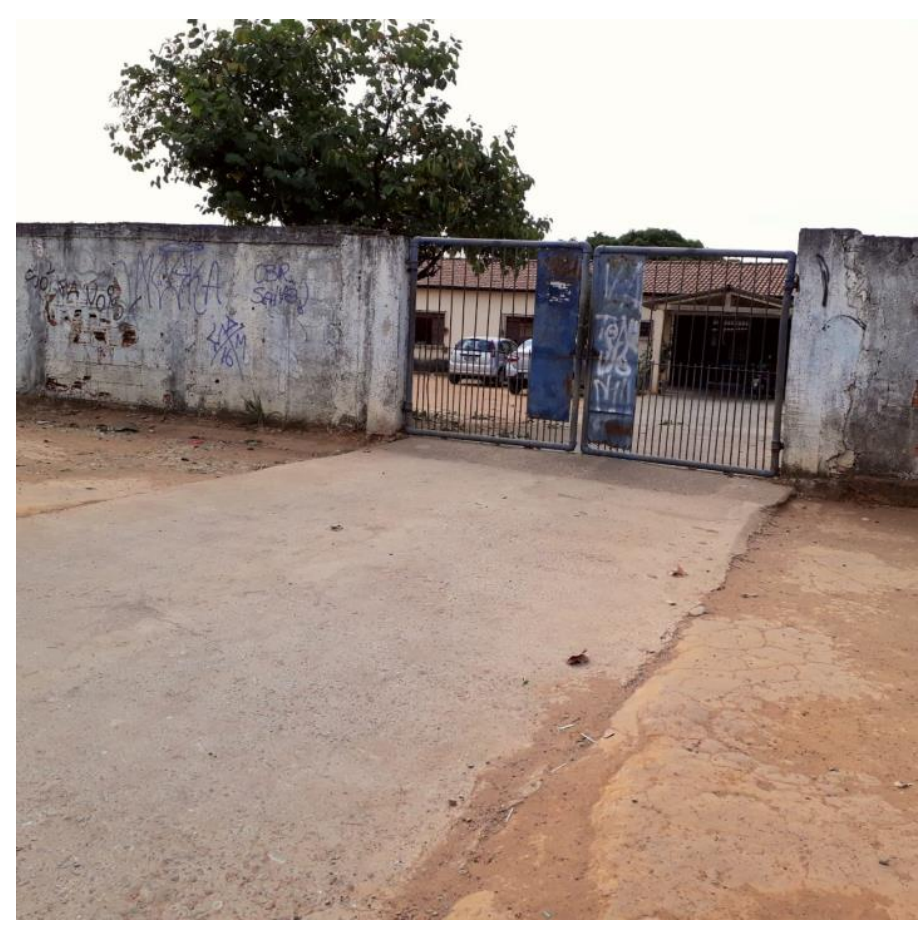

Imagem 01 - Escola Martins Pena 


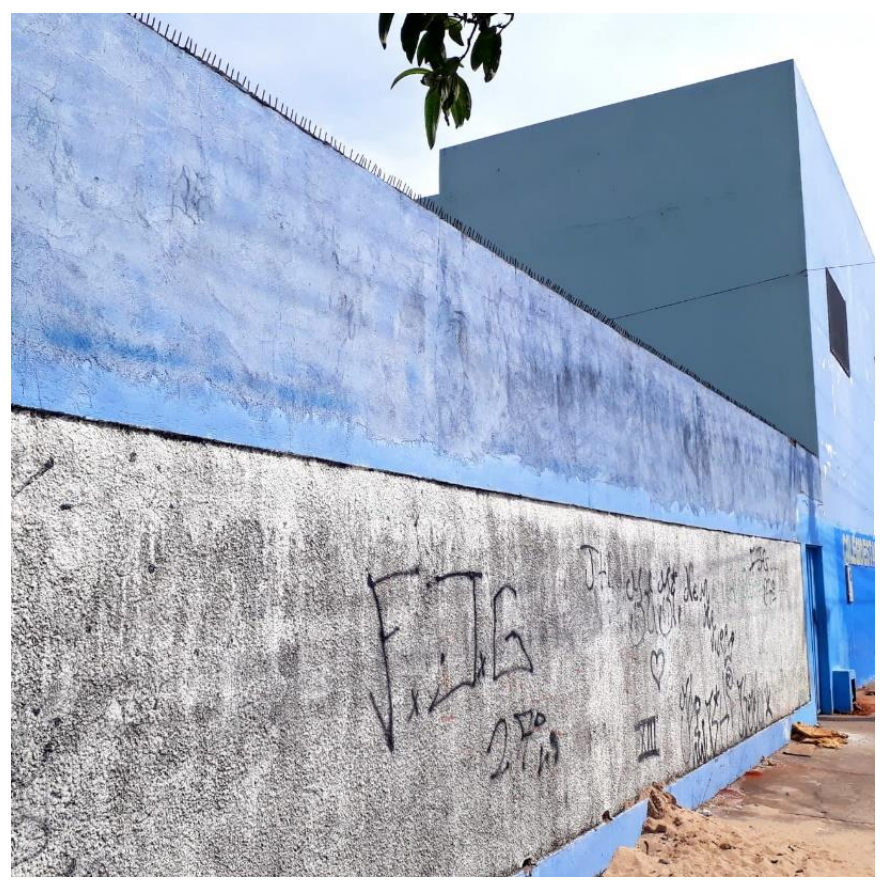

Imagem 02 - Escola Nelson

Rodrigues

As aparências da Escola Martins Pena e da Escola Nelson Rodrigues são assustadoras. Em primeira instância se assemelham a centros de recuperação de pequenos infratores. Muros altos e portões fechados como forma de garantir a segurança dos estudantes. Siglas e desenhos impressos nos muros para demarcar territórios e reafirmar o poder dos sujeitos que dominam a área próxima à escola.

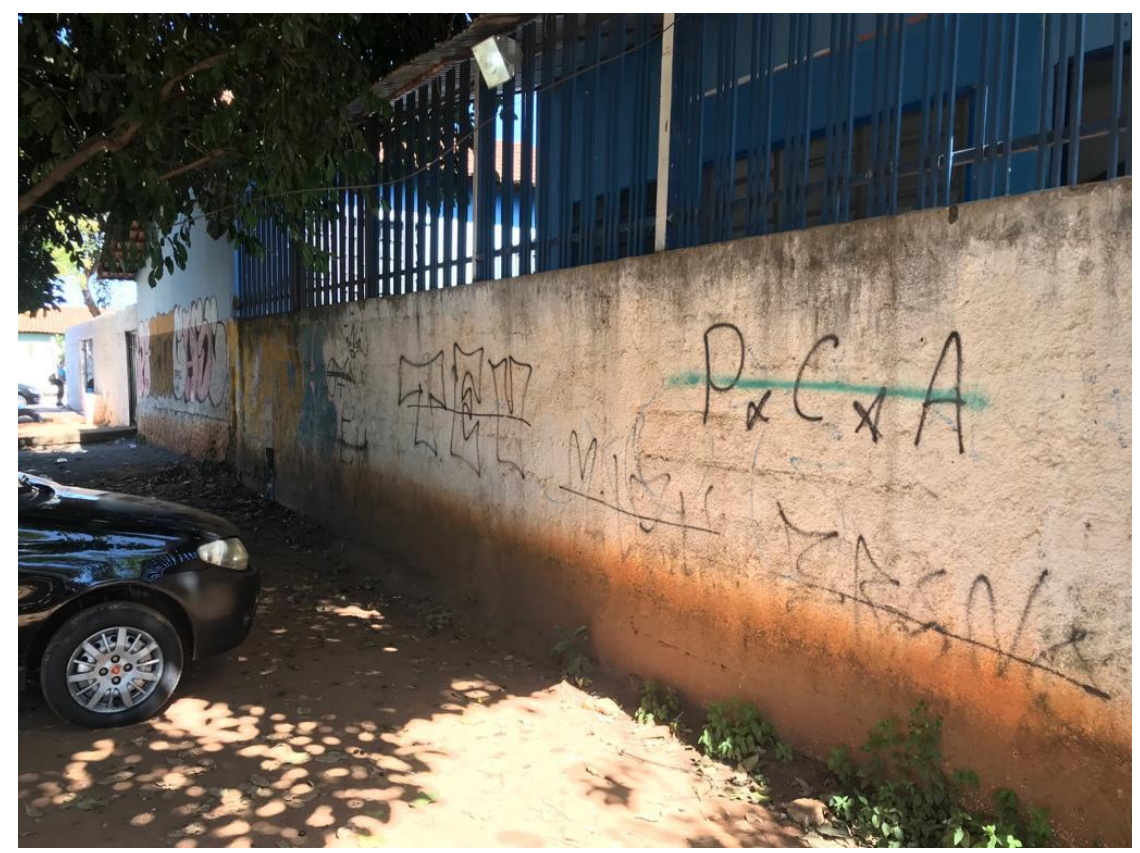

Imagem 03 - Siglas e desenhos no muro da Escola Nelson Rodrigues 
De fato, as estruturas das escolas não agradam. Elas deveriam ser possuidoras de uma aparência alegre e acolhedora e não se assemelhando a prisões com muros altos e janelas inacessíveis (SANTANA, 2010, p.02). Sobre esse assunto, Melatti (2010) investigou a arquitetura das escolas brasileiras. Em seu trabalho de pesquisa intitulado $A$ arquitetura escolar e a prática pedagógica, a autora afirma:

\begin{abstract}
A importância do ambiente escolar pode ser testada numa experiência simples e corriqueira: quando se leva uma criança pela primeira vez à escola, ela normalmente reage de forma imediata, demonstrando o impacto agradável ou não que lhe causou o "espaço", a estrutura, as cores, enfim, o conjunto físico do colégio (MELATTI, 2010, p.13).
\end{abstract}

Para Melatti (2010), a arquitetura das escolas revela muito mais do que a aparência. Ela revela modos de comportamento, de gosto e de sentimentos. Nesse contexto, não há nada de natural nos muros e dependências físicas das escolas, o que por sua vez denotam sentimentos de desconforto, apreensão, sofrimento e tortura. Raimann e Raimann (2008) desenvolveram estudos interessados em compreender a arquitetura escolar e suas implicações nos processos de disciplinarização dos corpos. De acordo com as autoras:

\begin{abstract}
A escola está arquitetonicamente projetada para um espaço disciplinar. Sua arquitetura evidencia um conceito racionalista que tem como principais características: linguagem formal, sem ornamentação, de formas simples e bem geométricas, com aberturas horizontais, integração dos espaços internos e externos, aberturas envidraçadas e, ainda, grandes corredores para uma boa circulação, utilizando o funcionalismo arquitetônico. $\mathrm{O}$ conjunto dos prédios escolares é organizado pela disciplina como um espaço de controle. Na estrutura física, tem-se o espaço distribuído para a direção, a secretaria, a biblioteca, a sala de professores e as salas de aulas. Nessas últimas, o próprio interior da sala de aula é ordenado espacialmente, criando um espaço útil. Assim, cada um dos alunos ocupa seu lugar específico, bem como os professores. (RAIMANN e RAIMANN, 2008, p.09).
\end{abstract}

É possível observar na narrativa das autoras a forma como a arquitetura escolar é construída para o desenvolvimento do controle e da disciplina, de forma a facilitar as ações de vigilância dos corpos escolares. Essa prerrogativa reafirma a predisposição dos espaços escolares na educação de corpos dóceis e obedientes.

Observando os estudantes esperando o horário de entrada no portão de acesso das escolas, foi possível detectar muitas frustações nas suas conversas. A angústia estampada no rosto das crianças que aguardavam o horário de entrada revelava a insatisfação com o espaço escolar. Enquanto esperavam, os estudantes dialogavam 
sobre atividades solicitadas pelos professores, punições recebidas, relacionamentos, jogos e insatisfações com a estrutura interna da escola.

De certo modo, a precariedade da maioria das escolas públicas da Rede Estadual de Ensino de Goiás dificulta a afirmação de uma política identitária na escola, assim como demonstram Ball, Maguire e Braun (2016) ao alegarem que "as formas que as escolas são equipadas internamente impactam nas atividades de ensino e aprendizagem e, portanto, nas atuações de políticas" (Ball; Maguire; Braun, 2016, p.54). Essa ausência de uma identidade escolar leva os sujeitos a imprimirem no espaço físico as suas marcas, expressividades e histórias. Sobre esse assunto, Carvalho (2012) reforça:

\begin{abstract}
No processo de construção de identidade, o ser humano estará, consciente ou inconscientemente, em apropriação contínua de outros textos ou discursos: midiáticos, literários, religiosos ou históricos, que, por sua vez, estabelecem um diálogo entre épocas, sociedades e espaços diversos. Por isso, os processos de comunicação abrangentes têm um papel de destaque no processo de construção das identidades, uma vez que representam um lugar privilegiado de produção de sentidos para as diversas práticas e referências sociais (CARVALHO, 2012, p. 214).
\end{abstract}

Considerando as ideias de Carvalho (2012), pode-se afirmar que os desenhos, as siglas e as frases presentes no muro de entrada das escolas investigadas representam processos desencadeadores de uma formação identitária que é singular e própria de cada lugar e de cada sujeito. Sobre a construção da identidade no espaço coletivo, Cabral (2017) ressalta:

\begin{abstract}
A identidade surge como uma fonte de significados com os quais sujeitos ou grupos tem consciência de si e se reconhecem. É o produto da organização social e simbólica de sua vida material e suas relações, construídas ao longo da história. [...] A construção da identidade, então, está relacionada à dinâmica das relações de dominação, exploração e exclusão social. [...] As identidades emergem nos bairros, nos centros, nas periferias, nas áreas industriais. O processo da busca de identidade cultural passa pelo caminho da educação (CABRAL, 2017, p.74).
\end{abstract}

Com as reflexões do autor, nota-se o movimento cotidiano dos corpos escolarizados e suas tentativas de construir identidades e, desse modo, afirmar pertenças individuais e coletivas. As expressões manifestadas nos muros e nas dependências das escolas simbolizam ideias e sentimentos que refletem no comportamento dos sujeitos nesses espaços. Observemos os muros da Escola Nelson Rodrigues nas fotos a seguir. A presença de ferraduras pontiagudas em cima dos muros demonstra o aprisionamento dos 
corpos, assemelhando-se a centros penitenciários, como se os corpos ali presentes estivessem sob um regime severo por serem perigosos e, por isso, devem ser controladas as suas saídas.

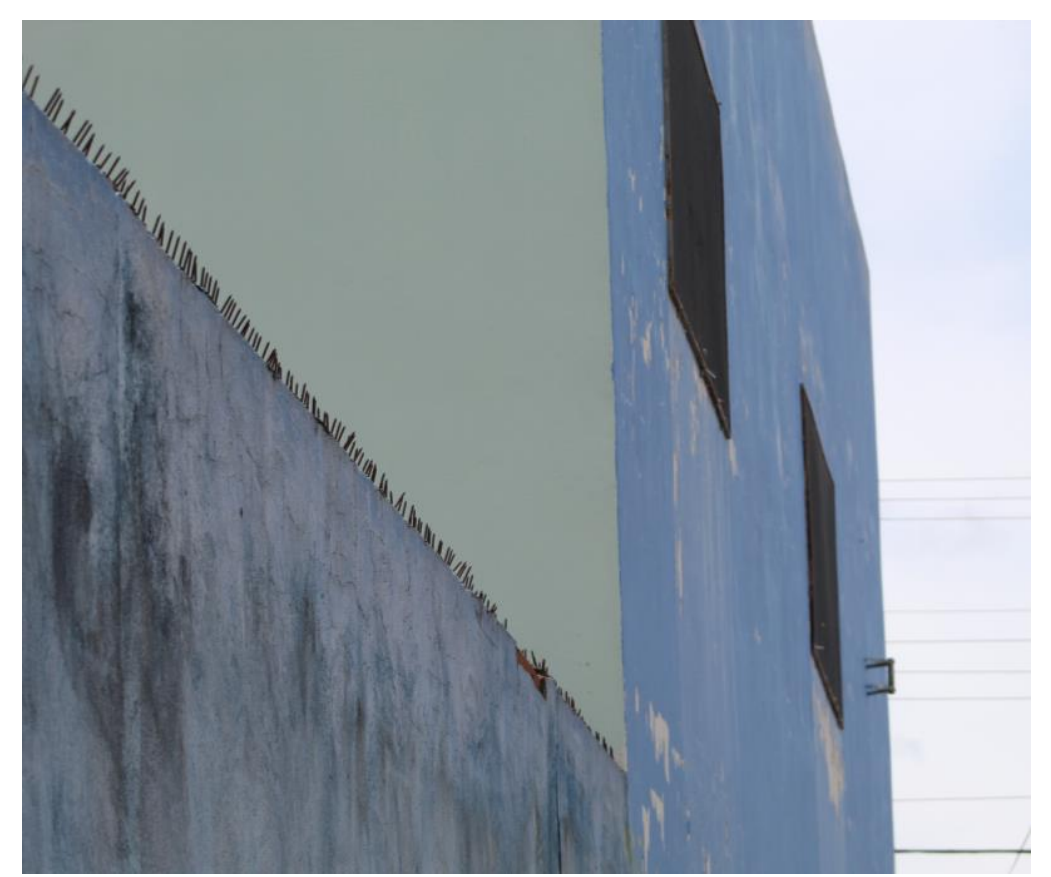

Imagem 4 - Vista externa do muro da Escola Nelson Rodrigues

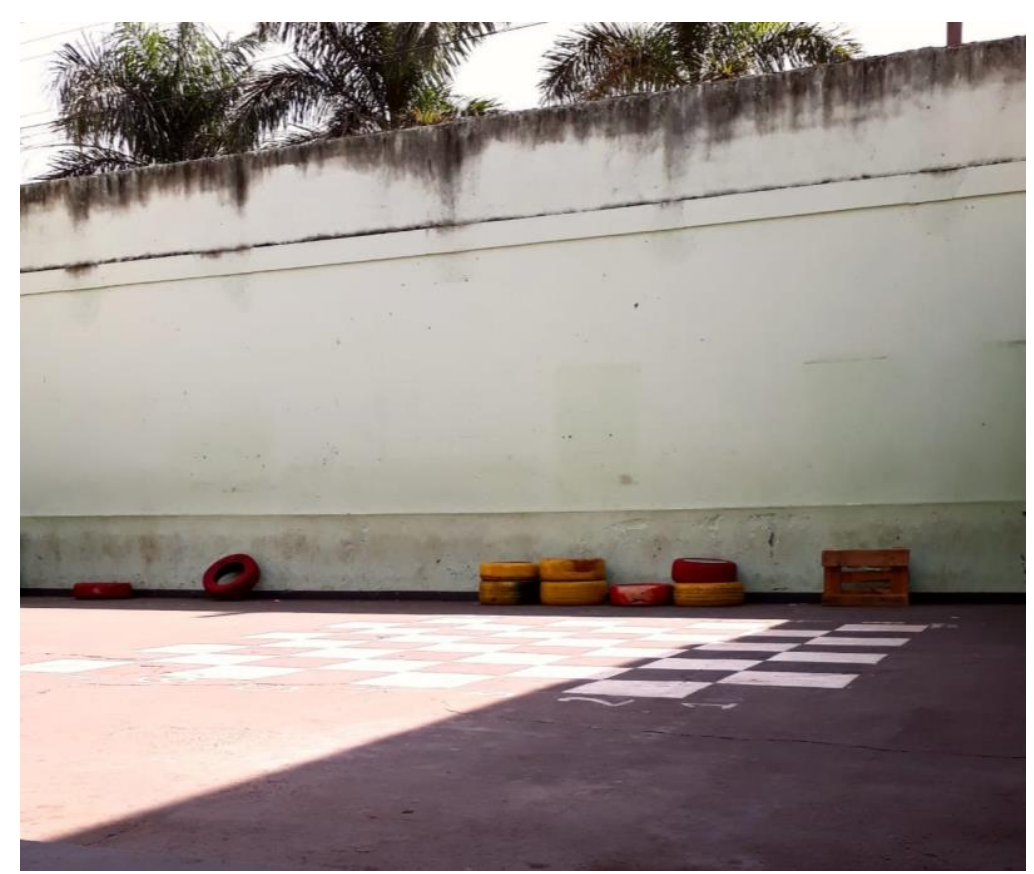

Imagem 5 - Vista interna do muro da Escola Nelson Rodrigues

Amparado em Foucault (1987), pode-se dizer que a organização dos muros escolares e seus equipamentos demonstram a necessidade desses aparato para as escolas, como forma de impedir o avanço da criminalidade nos espaços escolares. Desse 
modo, o aumento crescente da violência e das drogas explica a permanência dos muros altos.

\section{3 - A estrutura física interna: algumas revelações}

Não é novidade que a maioria das escolas públicas da Rede Estadual de Ensino de Goiás apresenta estruturas precárias e condições mínimas de aprendizagem. Mesmo assim, este fato não dispensa novas análises e interpretações, pois, a sociedade muda e com ela os sujeitos que constituem a escola. Novas práticas surgem, outras desaparecem e a relação com os espaços se reconstroem. Sobre esse assunto, Farah (2010) propõe:

\footnotetext{
Observar a existência ou não das salas ambientes, quadras, ginásio, teatro, parquinhos, cantinhos, espaços com árvores, plantas e flores, hortas e as condições de tais espaços, considerados específicos ao trabalho corporal, no qual podemos observar as condições de uso do piso, a ventilação, a cobertura da quadra no caso de mudanças climáticas, bem como considerar a existência dos espaços e tempos para a higiene dos alunos e o procedimento de manutenção da limpeza e dos recursos materiais desses espaços (FARAH, 2010, p. 407).
}

Partindo das ideias apresentadas por Farah (2010), é oportuno reafirmar a ausência de uma identidade escolar nas unidades pesquisadas. Em sua maioria, a estrutura se apresenta precária, com mobílias danificadas, condições de ventilação e iluminação insuficientes, além de uma aparência física semelhante a outros ambientes que pouco lembram uma escola disposta ao aprendizado. As imagens a seguir ajudam a enriquecer nosso argumento.

Observando rapidamente as referidas imagens, poderíamos dizer que a primeira imagem retrata um centro de tratamento de dependentes químicos devido a sua estrutura, incluindo as cores e a organização do espaço de convivência. A referida imagem pouco nos remete a uma escola. Do mesmo modo, poderíamos dizer que a segunda imagem retrata um centro de atendimento médico dotado de especialidades médicas distintas. No entanto, as duas imagens referem-se a uma mesma escola, denominada de Escola Maria Clara Machado. 


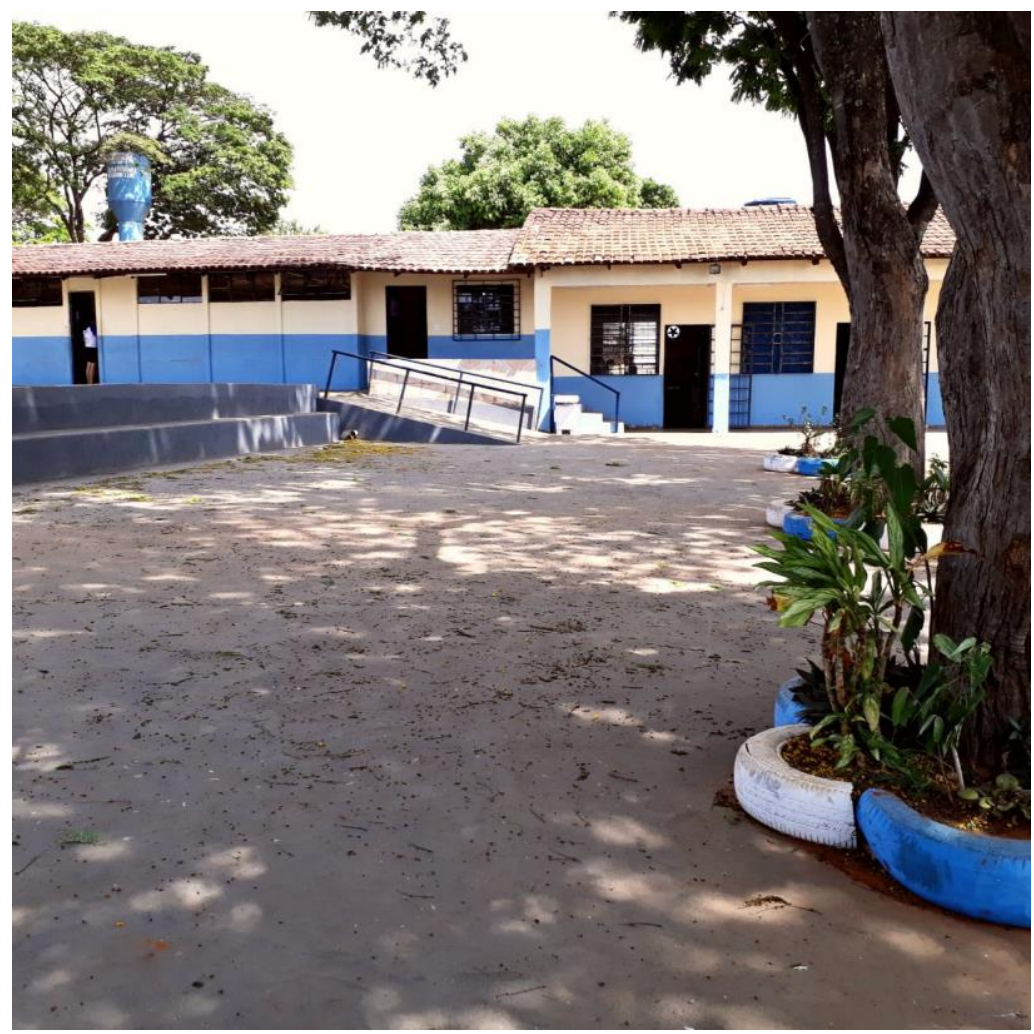

Imagem 06 - Vista do pátio da Escola Maria

Clara Machado

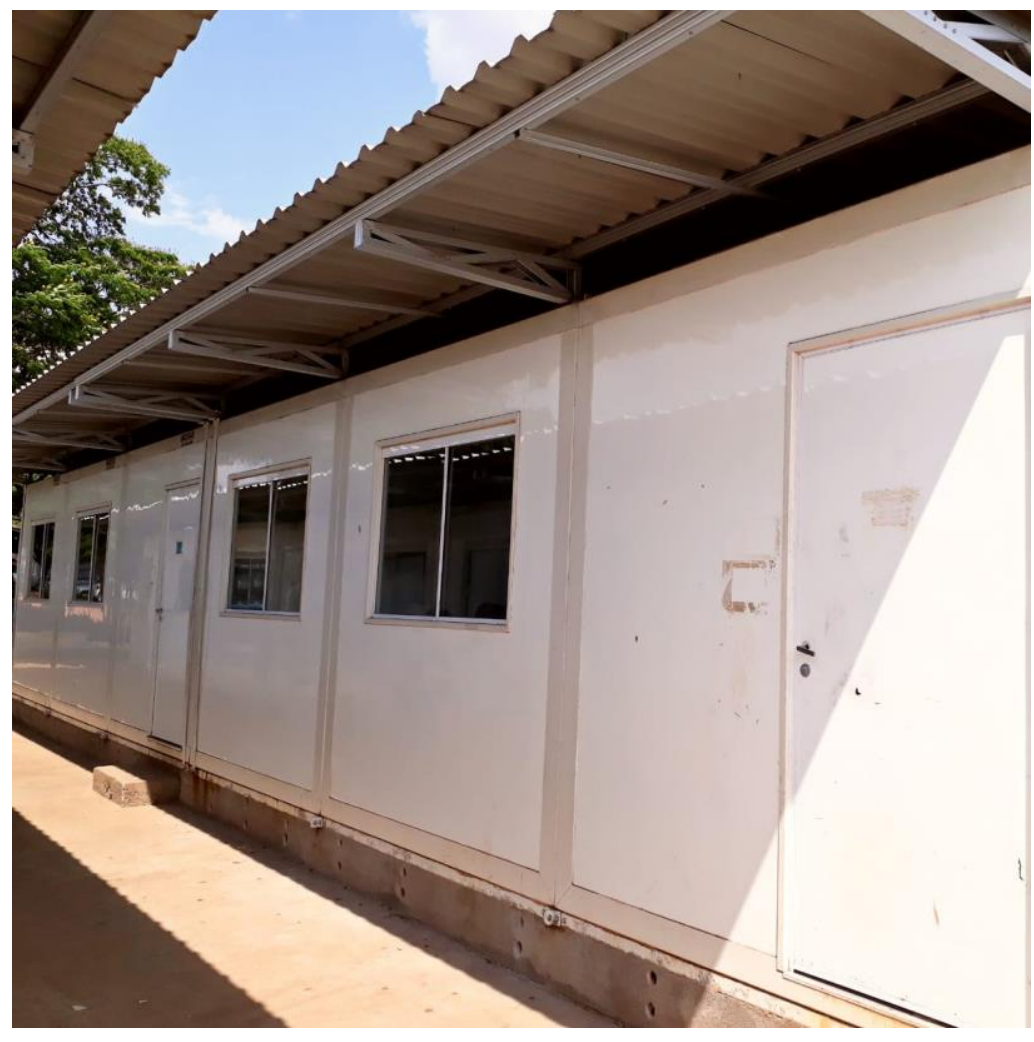

Imagem 07 - Bloco novo da Escola Maria Clara Machado 
É importante ressaltar que a segunda imagem acima representa o bloco novo da escola, construído a partir de contêineres de metal. Segundo o diretor, a medida improvisada foi tomada pela SEDUCE (Secretaria de Estado da Educação, Cultura e Esportes de Goiás) para atender a grande demanda por vagas na região. Ao todo, a Escola Maria Clara Machado possui oito salas de aula modulares nesse sistema. Podemos observar ainda na segunda imagem a ausência de condições de acessibilidade para estudantes cadeirantes. Amparados em diferentes autores, Santana (2010) afirma que o espaço escolar e sua estrutura são portadoras de processos educativos. De acordo com a autora:

\footnotetext{
Um ambiente limpo, organizado, bonito e atraente é um elemento educativo de grande força, estimulando a sensibilidade criativa e artística do aluno, pois, como afirmam os próprios autores, o espaço não é neutro, sempre educa. [...] Não basta apenas garantir o acesso à escola, é necessário que haja também condições para o desenvolvimento e aprendizagem dos educandos. A falta de conforto, em todos os seus aspectos, influi no desempenho dos alunos na sala de aula, tanto em termos de saúde quanto de aprendizado (SANTANA, 2010, p.09).
}

Acompanhando os apontamentos realizados por Santana (2010), reforça-se a necessidade de os governantes e gestores escolares repensarem a estrutura das escolas. Será que essas estruturas físicas possibilitam novas experiências corporais favoráveis a aprendizagem escolar? Bem, ao observar o comportamento dos estudantes na Escola Maria Clara Machado, verificou-se a existência de sentimentos favoráveis relativos as salas de aula de contêineres devido a presença dos aparelhos de ar condicionado. No entanto, a agitação das crianças e a preocupação com o horário de saída eram enormes. O mesmo sentimento de descontentamento aparecia em suas movimentações corporais. Em quase todas as aulas, quando as sirenes tocavam para indicar o término de cada aula, os alunos expressavam gritos comemorativos e glorificavam figuras sagradas como forma de agradecimento pelo término de mais uma aula.

De modo geral, essas situações confirmam o sofrimento de seus corpos em permanecerem inertes durante a maior parte do tempo em que permanecem na escola. Como prática, ao final de cada aula, os estudantes se movimentavam, espreguiçavam e uma parte considerável se concentrava na porta das salas. Ali trocavam olhares com estudantes de outras salas, conversavam e alimentavam uma brincadeira de empurrar os estudantes da porta para fora da sala de aula. Outros brincavam e corriam pelo interior 
das salas. Cada um, ao seu modo, demonstrava a necessidade de movimentos não permitidos durante as aulas.

Durante o recreio na Escola Maria Clara Machado, os estudantes se concentravam na quadra da escola, espaço localizado longe da vista dos professores e coordenadores. Em sua maioria, as atividades se relacionavam a correr, pular, conversar e brincar. Segundo Farah (2010):

O recreio se constitui como o único momento em que não deveria haver uma proposta diretiva, para que crianças e alunos possam construir suas próprias hipóteses de movimento, de brincadeira, de agrupamentos entre si, de uso de materiais (FARAH, 2010, p.407).

Amparado nas ideias de Farah (2010), a proposta de educação do corpo de outra escola, a Escola Nelson Rodrigues, preocupou bastante. Diferente da Escola Maria Clara Machado, a escola Nelson Rodrigues não possui recreio. Segundo a coordenadora da escola, o recreio foi suspenso porque as crianças corriam muito, caíam e se machucavam. Esse depoimento revela como as concepções pedagógicas dos docentes são fragilizadas. Ao invés de educar os corpos das crianças para evitar acidentes, os professores e coordenadores decidiram suspender o recreio. Com esse episódio, começa-se a desvelar os motivos que levam as crianças da Escola Nelson Rodrigues a apresentarem comportamentos de indisciplina, assim como veremos no tópico a seguir.

\section{4 - Os sistemas de controle e de punição escolar}

O corpo ao adentrar o ambiente escolar fica sujeito a obedecer a uma série de regras combinadas pela escola. A maioria delas seguem rituais naturalizados: a) horários de entrada, permanência e saída; b) espaços de ocupação permitidos e não permitidos; c) modos de agir e de comportamento; d) vestimentas e adereços liberados; e) disponibilidade para preencher extensas folhas do caderno com letras e números; f) dentre outros. Todas essas regras compõem os sistemas de organização das escolas para o controle dos corpos. São regras, em sua maioria, registradas em um documento denominado Regimento Escolar. Como se observa, as normativas têm a finalidade de adestrar os corpos e, caso necessário, puni-los. O sistema de controle e de punição 
escolar formam um conjunto arquitetado para dominar, adestrar e docilizar os corpos escolarizados.

A estruturação do sistema de controle e de punição escolar, encontrado no Regimento Escolar, advém de documentos maiores, como é o caso da Lei de Diretrizes e Bases da Educação Nacional - LDB/9.394/1996 que dispõem de uma série de regulamentações e atribuições aos sujeitos envolvidos no processo de ensino e aprendizagem. Em conversas com os diretores das escolas, verificou-se que a narrativa teórica do Regimento Escolar é construída sob a ótica da referida lei.

Após a elaboração do Regimento Escolar, as escolas encaminham o referido documento para as secretarias de educação onde são analisados e aprovados. Nenhuma das regras elaboradas pelas escolas pode ferir as cláusulas da LDB/96. Por conta disso, em ocasiões oportunas, os professores se reúnem nas escolas para discutir e reelaborar o Regimento Escolar, de modo que este atenda às necessidades de dominação da escola, no caso de vigiar, controlar e punir os corpos escolarizados. Como se vê, o sistema de controle e punição é uma construção organizada por meio de organismos nacionais, estaduais, municipais e regionais.

$\mathrm{Na}$ Escola Nelson Rodrigues, além da ausência do recreio, existe um sistema de controle que trabalha em paralelo com o sistema de punição, denominado de AD Avaliação Disciplinar. Nesse sistema, ao início de cada bimestre, o aluno é portador de uma nota com valor de 10,0 pontos. Para manter a referida nota, os alunos devem obedecer a uma série de normativas preestabelecidas no regimento da escola. Caso um aluno descumpra essas normativas, ele é punido com a diminuição de sua AD.

Observando o referido documento, nota-se que o estudante é obrigado pelo sistema de controle e punição a manter uma postura comportamental considerada adequada pela instituição. Para o funcionamento deste sistema, a referida escola adotou um procedimento denominado "Ficha de ocorrência disciplinar". Esta ficha é utilizada pelos professores e coordenadores para registrar as "penalidades" cometidas pelos estudantes e, desse modo, diminuir a sua nota disciplinar. As imagens a seguir revelam as possíveis ocorrências, cabendo ao professor ou coordenação realizar o seu preenchimento. 
OCORRÊNCIA DISCIPLINAR - AnO 2019

Aluno (a):

N.Q: Bimestre

Professor (a)/Coord.(a): Disciplina:

Série: Turma: Turno:

\section{*TRANSGRESSŌEs LeVes}

Não realizar as atividades propostas pelo professor (atividades para casa, em sala...).

Sair ou entrar na sala de aula/escola sem autorização do professor, coordenador ou diretor.

Perambular pelos corredores durante as aulas.

Não trazer para a escola o material (livros, cadernos...) referente às aulas do dia de acordo com horário ou orientação prévia do professor.

Ocupar-se durante as aulas com trabalhos estranhos às mesmas.

\section{*TRANSGRESSŌES MÉDIAS}

Perturbar as aulas com conversas paralelas e/ou brincadeiras desagradáveis.

Praticar atos fisicos, tais como beijos, abraços, sentar no colo, trocar carícias, ou outras atitudes que demonstrem uma relação intima ou exceder na conduta pessoal durante a permanência na escola, tanto no horário normal de aula quanto nas aulas diversificadas, apresentações e eventos realizados promovidos pela Unidade Escolar.

Entrar na escola sem o uniforme.

Usar bonés, toucas, gorros, faixas ou similares, bem como, roupas inadequadas ao ambiente escolar (decote, transparência saia e bermudas muito curta, calça ou bermudas de tecidos leves).

Entrar e/ou permanecer em outras dependências da escola - que não sejam destinadas a alunos - a menos que sejam convidados.

Fumar nos corredores e demais dependências da escola.

\section{*TRANSGRESSŌES GRAVES}

Praticar Bullying psicológico, moral, sexual, verbal ou virtual (humilhar, discriminar, intimidar, difamar, assediar, insultar, apelidar pejorativamente, ciberbullying, dentre outros).

Praticar ato de violência contra a diversidade étnica, religiosa, sexual ou de gênero.

Utilizar-se de meios ilegais na realização de atividades escolares ou avaliaçōes.

Discutir, desrespeitar, agredir, mesmo que verbalmente, seus colegas.

Promover algazarra e distúrbios dentro da sala de aula, com ou sem a presença do professor.

Faltar com a verdade em conversas que envolvam o nome da escola, funcionários e/ou colegas

Rasurar, fraudar, adulterar qualquer documento escolar.

Convidar pessoas alheias a entrar na escola sem a autorização de um funcionário responsável.

Causar danos ao patrimônio escolar e a terceiros (cabendo indenização aos prejuizos nos casos de aluno reincidente com a referida transgressão).

Interferir nas normas de administração internas da escola, salvo por seus representantes.

Usar ou deixar tocar o CELULAR, usar fone de ouvido, tablet, MP3 e/ou similares durante o decorrer aulas.

Imagem 08 - Vista anterior da Ficha de Ocorrência Disciplinar 


\section{"TRANSGRESSŌES GRAVISSIMAS}

Cometer injúria, calúnia, agressão fisica, afrontar ou faltar com o devido respeito e/ou dirigir qualquer tipo de ameaça contra qualquer integrante da comunidade escolar.

Promover ou participar de brigas e/ou tomar atitudes inadequadas ao comportamento social, nas dependências da escola, em suas imediações, ou quando estiver uniformizado.

Omitir, contribuir ou participar de ações / movimentos terroristas ou de hostilidade ou desprestigio a Unidade Escolar, ao seu pessoal e as autoridades constituídas.

Divulgar em qualquer meio de comunicação assuntos ou imagens que envolvam, direta ou indiretamente, o nome da escola e seus servidores, sem a permissão das autoridades competentes.

Usa qualquer tipo de droga, sejam elas, lícitas (fumo, álcool, etc.) ou ilicitas.

(maconha, cocaina, crak, etc.) ou ainda importar ou exportar, remeter, preparar, produzir, vender, oferecer, ainda que gratuitamente, ter em depósito, transportar, prescrever, ministrar ou entregar, qualquer forma de substância entorpecente ou que determine dependência química.

Trazer para escola objetos pontiagudos, explosivos, armas branca ou de fogo, ou quais outros que possam oferecer risco de acidentes ou morte, a qualquer integrante da comunidade escolar.

*Em concordância com Regimento Escolar, LDB, Constituição Brasileira, Código Penal

Fato ocorrido:

\begin{tabular}{|c|c|}
\hline PONTOS PERDIDOS (PRIMÁRIO) & \\
\hline Transgressão leve................ 1 ponto & ( ) \\
\hline Transgressão média.............. 2 pontos & ( ) \\
\hline Transgressão grave.............. 3 pontos & ( ) \\
\hline Transgressão gravissima....... 5 pontos & (1) \\
\hline
\end{tabular}

\begin{tabular}{|c|c|}
\hline PONTOS PERDIDOS (REINCIDENTE) & \\
\hline Transgressão leve............... 2 pontos & ( ) \\
\hline Transgressão média.............. 4 pontos & ( ) \\
\hline Transgressão grave.............. 6 pontos & ( ) \\
\hline Transgressão gravissima....... 10 pontos & ( ) \\
\hline
\end{tabular}

De acordo com o Fato Ocorrido, o Grupo Gestor/Coordenação resolve:

Repreensão por escrito pela vez

O aluno fica suspenso das atividades escolares por dias

Transferência Pedagógica.

Outras observações:

CIENTE:
Aluno(a):
Responsável pelo aluno(a):
Professor(a):
Direção/Coordenação:

Direção/Coordenação, aos 1

Imagem 09 - Vista posterior da Ficha de Ocorrência Disciplinar 
Alguns elementos presentes na "Ficha de ocorrência disciplinar" precisam ser analisados. Primeiramente, o termo transgressão e em seguida o termo repreensão. Segundo o Dicionário Aurélio, da Língua Portuguesa, o termo transgressão significa ato ou efeito de transgredir; infração; quebra. No mesmo dicionário, o termo repreensão significa ato ou efeito de repreender; censura, reprimenda, reprovação; sarabanda. Observa-se, por meio desses conceitos, que a escola imprime nos corpos escolarizados não obedientes uma condição de criminalidade, culminando em uma violência simbólica (BOURDIEU, 2001). Esta prática condiz com as ideias apontadas por Foucault (1987), no qual os estudantes têm suas condutas examinadas durante todo o tempo em que permanecem no ambiente escolar.

Qualquer conduta fora das normativas estabelecidas são passíveis de penalização. Nesse caso, a pena não se baseia em um castigo corporal, mas os sujeitos sofrem com a diminuição de notas, podendo levá-lo a uma reprovação no final de período letivo, o que demonstra o poder autoritário da escola sobre os estudantes. De acordo com Boal (2009), todo poder autoritário é violência. Trata-se de uma violência simbólica, nos termos atribuídos por Bourdieu (1996):

É uma violência que se exerce com a cumplicidade tácita daqueles que a sofrem e também, frequentemente, daqueles que a exercem na medida em que uns e outros são inconscientes de a exercer ou a sofrer (BOURDIEU, 1996, p.16).

Podemos perceber, por meio da narrativa do autor, o quanto os espaços escolares promovem violência simbólica. Sobre os corpos que apresentam condutas fora das normativas estabelecidas, as escolas agem promovendo práticas autoritárias e, por isso, violência simbólica. Ao abordar a questão da disciplina, Foucault (1987) afirma:

\begin{abstract}
O sucesso do poder disciplinar se deve sem dúvidas ao uso de instrumentos simples: o olhar hierárquico, a sanção normalizadora e sua combinação num procedimento que lhe é específico, o exame. O exercício da disciplina supõe um dispositivo que obrigue pelo jogo do olhar; um aparelho onde as técnicas que permitem ver induzam a efeitos de poder, e onde, em troca, os meios de coerção tornem claramente visíveis aqueles sobre quem se aplica (FOUCAULT, 1987, p.143).
\end{abstract}

Ao observar a conduta corporal dos professores e estudantes em sala de aula na Escola Nelson Rodrigues, notou-se a imposição do poder e da disciplina imposta por alguns professores sobre os alunos. O olhar minucioso de vigilância, a postura em pé, as 
gesticulações, os apontamentos com os dedos e as ordens para o cumprimento de atividades demonstraram a superioridade e imposição dos professores. Qualquer manifestação contrária à proposta pelo professor poderia acarretar complicações, resultando na perda de nota disciplinar. Nesse sistema, alguns professores salientaram que o estudante está em processo de formação e, portanto, deve obedecer a todas as regras para ter sucesso na vida. Verificou-se que o olhar docente na Escola Nelson Rodrigues é de fiscalização constante acerca das ações e atitudes dos alunos.

Como se observa, o corpo não pode errar ou cometer atos fora das normativas porque a escola não aceitará e, conforme a "Ficha de ocorrência disciplinar", o aluno não obediente deverá sofrer as penalidades cabíveis ao Regimento Escolar. Desse modo, esse sistema demonstra que os corpos escolarizados devem mostrar-se obedientes ou então sofrerão punições severas, como por exemplo ser transferido para outra unidade escolar um pouco mais distante. Conforme aponta Oliveira (2006):

Desde cedo, todo e qualquer aluno identifica e aprende a seguir várias regras que colaboram para o desenvolvimento de um autocontrole sobre suas ações no âmbito escolar, e que, em maior ou menor grau, representam algum tipo de sacrifício, seja ele corporal ou não (OLIVEIRA, 2006. p.60).

As ideias de Oliveira (2006) corroboram para o entendimento de que a escola é uma instituição promovedora de regras para o desenvolvimento do autocontrole sobre os corpos. De certo modo, é um autocontrole necessário em determinados momentos para a prática do ensino e da aprendizagem. Porém, o que se questiona são os modos opressores pelos quais se mostra essa educação do corpo e a insistência em um modelo adestrador, dominador, controlador e punitivo. Segundo Oliveira (2006):

Precisamos reconhecer que a aproximação que o indivíduo estabelece com os saberes requer uma certa disciplina corporal que forneça condições para que possa ter acesso ao conhecimento e ao esclarecimento. Sem ela o processo educacional enfrentaria uma série de dificuldades que acabariam interferindo sobre a qualidade dos conhecimentos assimilados e, consequentemente, sobre o valor destes para a formação. A falta de disciplina pode colaborar para a perpetuação da dominação, por meio da negação do acesso à cultura, ao esclarecimento, resultando na impossibilidade de diferenciação. Por esse ângulo, é fundamental lembrarmos que o indivíduo diferenciado só pode refletir a cultura porque já conseguiu entendê-la, usufruí-la, conhecê-la, enquanto o indivíduo não diferenciado acaba adaptando-se imediatamente a ela, pois não possui elementos para realizar qualquer forma de análise e questionamento. Então, se é possível afirmar que a liberdade é condição para uma formação séria, também é possível dizer que esse processo deve estar orientado por alguns critérios que garantam a possibilidade de autorreflexão. [...] Por conseguinte, a disciplina corporal não pode ser realizada de maneira 
arbitrária, produzindo corpos disciplinados que não reflitam sobre sua necessidade (OLIVEIRA, 2006, p.61).

Em concordância com a autora, os processos disciplinares na escola devem ocorrer para que os estudantes tenham condições de apropriação do conteúdo trabalhado pelos professores. Assim, tanto as práticas escolares quanto as estruturas físicas merecem novas leituras e análises, principalmente aquelas direcionadas para $\mathrm{o}$ desenvolvimento de controles rigorosos, punitivos e de coibição dos movimentos corporais e seus saberes. É preciso reafirmar a necessidade do corpo presente nos processos de ensino e aprendizagem escolar. Não um corpo inerte, morto, desanimado, mas um corpo vivo, carregado de expressividades, de curiosidades e disposto a descortinar as amarras sociais, as injustiças e as contradições. Devemos obedecer, seguir padrões, rituais de beleza e comportamento para sermos aceitos. Caso contrário, seremos punidos apenas por sermos corpos não correspondentes aos modelos e normativas estabelecidas.

Sobre a condição da disciplina, Foucault (1987) afirma que ela assume um papel determinante nos processos de controle e punição. Segundo o autor:

\footnotetext{
A disciplina "fabrica" indivíduos; ela é a técnica específica de um poder que toma os indivíduos ao mesmo tempo como objetos e como instrumentos de seu exercício. Não é um poder triunfante que, a partir de seu próprio excesso, pode-se fiar em seu superpoderio; é um poder modesto, desconfiado, que funciona a modo de uma economia calculada, mas permanente (FOUCAULT, 1987, p.143).
}

Conforme a narrativa de Foucault (1987), a disciplina é um recurso poderoso de controle do corpo e que merece constantes análises interessadas em entender seus mecanismos. Evidenciando a análise da Escola Nelson Rodrigues, observou-se ainda o uso de castigos corporais como uma forma de punição situado acima do sistema Avaliação Disciplinar - AD mencionado anteriormente. Nesse sistema, quando o estudante em sala de aula comete muitas "transgressões" e o professor não consegue mais controlá-lo, ele é encaminhado para a coordenação.

$\mathrm{Na}$ coordenação, os estudantes têm suas condutas corporais reavaliadas. $\mathrm{O}$ coordenador inicia um processo interrogatório semelhante a um processo de julgamento, onde deve ouvir todos os fatos ocorridos e determinar uma sentença punitiva a partir do nível dos fatos e do grau de arrependimento do estudante. Sem se dar conta de que se trata de uma punição corporal, a coordenação priva o estudante de retornar para a sala 
de aula, obrigando-o a permanecer sentado no corredor próximo a sala da coordenação por um longo período.

O espaço do corredor destinado à prática do castigo é visto pela equipe pedagógica da escola como uma ação estratégica. Primeiro porque o estudante fica sob a vigia da coordenação. Segundo porque é uma forma de demonstrar aos demais alunos o que pode lhe acontecer caso infrinja alguma normativa. De modo geral, se o ato punitivo de diminuir notas não funcionar, a Escola Nelson Rodrigues apela para o uso da punição corporal. Conforme Foucault (1987), é preciso punir exatamente o suficiente para impedir que este estudante transgressor não venha a desobedecer novamente às regras implantadas na escola.

As imagens a seguir demonstram um desses momentos ocorridos com três estudantes do ensino fundamental. Uma professora da escola retirou os estudantes da sala de aula porque eles estavam conversando muito e demonstrando desinteresse na resolução de atividades do livro.

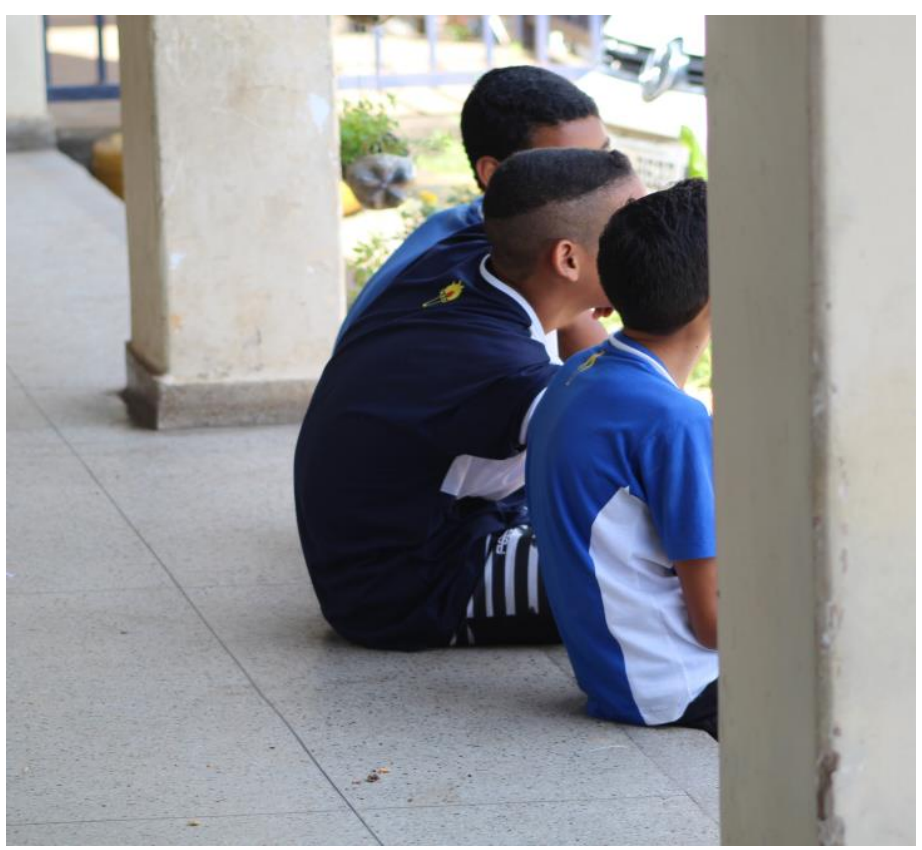

Imagem 10 - Estudantes cumprindo castigo corporal por desobediência - A

Como se vê, em nome da aprendizagem, a Escola Nelson Rodrigues desenvolveu um procedimento de controle e punição para os corpos desobedientes. Para a coordenação da escola, a decisão de colocar os estudantes sentados no corredor representa uma oportunidade para eles repensarem acerca da postura e comportamento em sala de aula. Na prática, parecem não haver muitas diferenças com a sala de aula, uma vez que os corpos deverão cumprir regras, normas e condutas. 


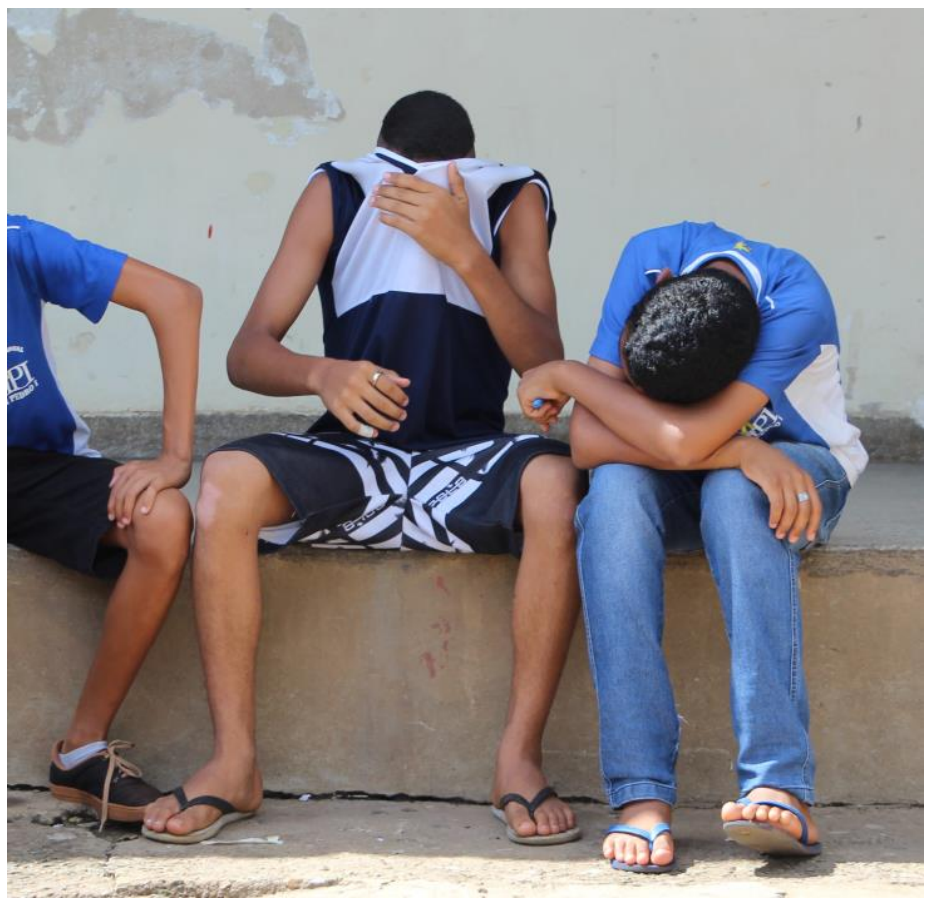

Imagem 11 - Estudantes cumprindo castigo corporal por desobediência - B

De modo geral, uma escola onde os estudantes não possuem recreio e devem ficar quietos e sentados durante toda a tarde pode justificar um pouco da atitude destes alunos. Portanto, cabem algumas indagações pertinentes sobre esse episódio: Será que os corpos destes estudantes foram considerados na aula desta professora? Será que estas punições resolverão os problemas de inquietude corporal? Por meio desse fato, constatase que a escola não entende o corpo como um lugar, conforme explicam Rios e Moreira (2015):

\footnotetext{
repleto de multiplicidades. Ele é ao mesmo tempo social, psicológico, biológico e transcendente, mas sempre foi considerado inferior, como segundo plano na sala de aula em relação à mente. Devemos entender o corpo e a mente como componentes que integram o mesmo organismo e estabelecer um elo entre o movimento e o desenvolvimento mental da criança, pois esta, desde o seu nascimento é movimento constante e na escola levamos o aluno a uma imobilidade excessiva, contrariando todas as características da infância (RIOS e MOREIRA, 2015, p.50).
}

As ideias dos autores acima contribuem para reforçar a necessidade de considerarmos o corpo nos processos de ensino e aprendizagem escolar. Se insistirmos em negá-lo, estes problemas envolvendo a indisciplina corporal continuarão a fazer parte do cotidiano escolar. É preciso dizer que não apenas as ações didáticopedagógicas devem ser pensadas. 
A estrutura das escolas também carece de olhares sensíveis. Na Escola Nelson Rodrigues, por exemplo, há um sistema em operação organizado para o cumprimento de regras, normas e leis. Esse sistema abrange desde as ações pedagógicas às estruturas físicas das escolas. É um sistema organizado para a domesticação dos corpos escolarizados.

Pensando nesse sistema, podemos observar como os muros altos das escolas somado a outros artifícios físicos participam de forma efetiva no controle da circulação dos corpos escolarizados e não escolarizados. Usam-se grades, correntes e cadeados para controlar ou impedir o acesso a determinados espaços.

Nesse sistema de coibição, caso um estudante ocupe um espaço da escola em tempos não permitidos, deverão ser punidos pelo sistema $\mathrm{AD}$ - Avaliação Disciplinar, ou quem sabe pelo sistema de castigos corporais. De modo geral, percebe-se que a Escola Nelson Rodrigues adota esse sistema para facilitar o desenvolvimento de suas atividades, pois, ainda de acordo com Foucault (1987):

\footnotetext{
Importa estabelecer as presenças e as ausências, saber onde e como encontrar os indivíduos, instaurar as comunicações úteis, interromper as outras, poder a cada instante vigiar o comportamento de cada um, apreciá-lo, sancioná-lo, medir as qualidades ou os méritos. Procedimento, portanto, para conhecer, dominar e utilizar. A disciplina organiza um espaço analítico (FOUCAULT, 1987, p.123).
}

Em nome da segurança dos equipamentos e das pessoas envolvidas com a prática de ensino, as escolas visitadas consideram necessária a instalação de grades, cadeados e fechaduras reforçadas em portas, janelas e corredores de acesso. É certo que um dos problemas deste mundo é o aumento estrondoso da criminalidade, mas, existem alternativas para minimizar o impacto dessas medidas no comportamento dos alunos e de todas as pessoas que frequentam a escola e estas nem sempre são adotadas.

Em uma das escolas investigadas, por exemplo, a diretora acusou o registro de sete furtos a objetos da escola em um período de seis meses. Situações semelhantes de furtos foram relatados pelos professores e gestores das demais escolas, fato que tem levado as escolas a adotarem grades e cadeados em seus espaços.

De fato, enquanto educadores, é preciso pensar no modo de operação desse sistema no cotidiano escolar, na forma como ele é utilizado em relação à educação do corpo e nas representações que elas suscitam. Sobre esse assunto, observemos as imagens a seguir. Elas demonstram a presença excessiva das barreiras de ferro para 
restringir o acesso e circulação dos corpos escolares e não escolares nas escolas investigadas. Como observado, ao assumirem essas características, as escolas normatizam procedimentos de ocupação dos corpos escolares e não escolares. Em síntese, a presença das grades é explicada pelo fator da insegurança. No entanto, observa-se também a privação desses espaços escolares aos estudantes, o que não se justifica.

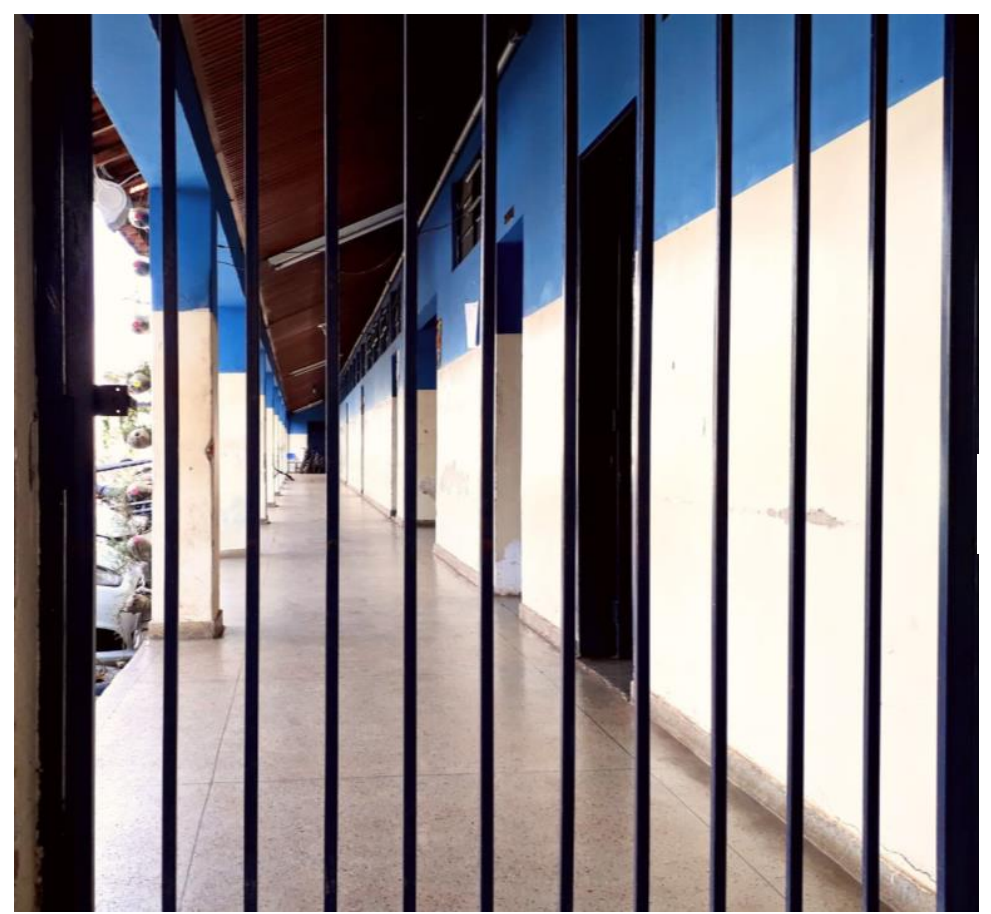

Imagem 12 - Acesso à

Escola Nelson Rodrigues

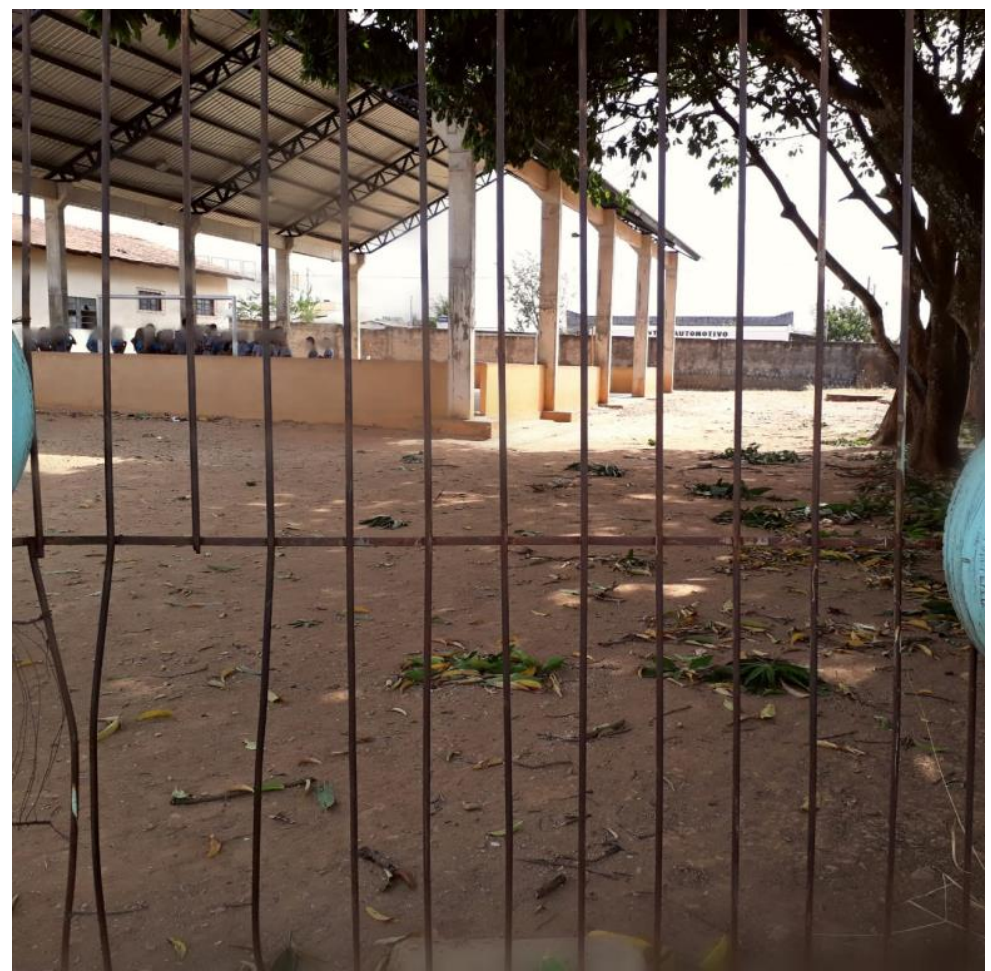

Imagem 13 - Acesso à

Escola Martins Pena 


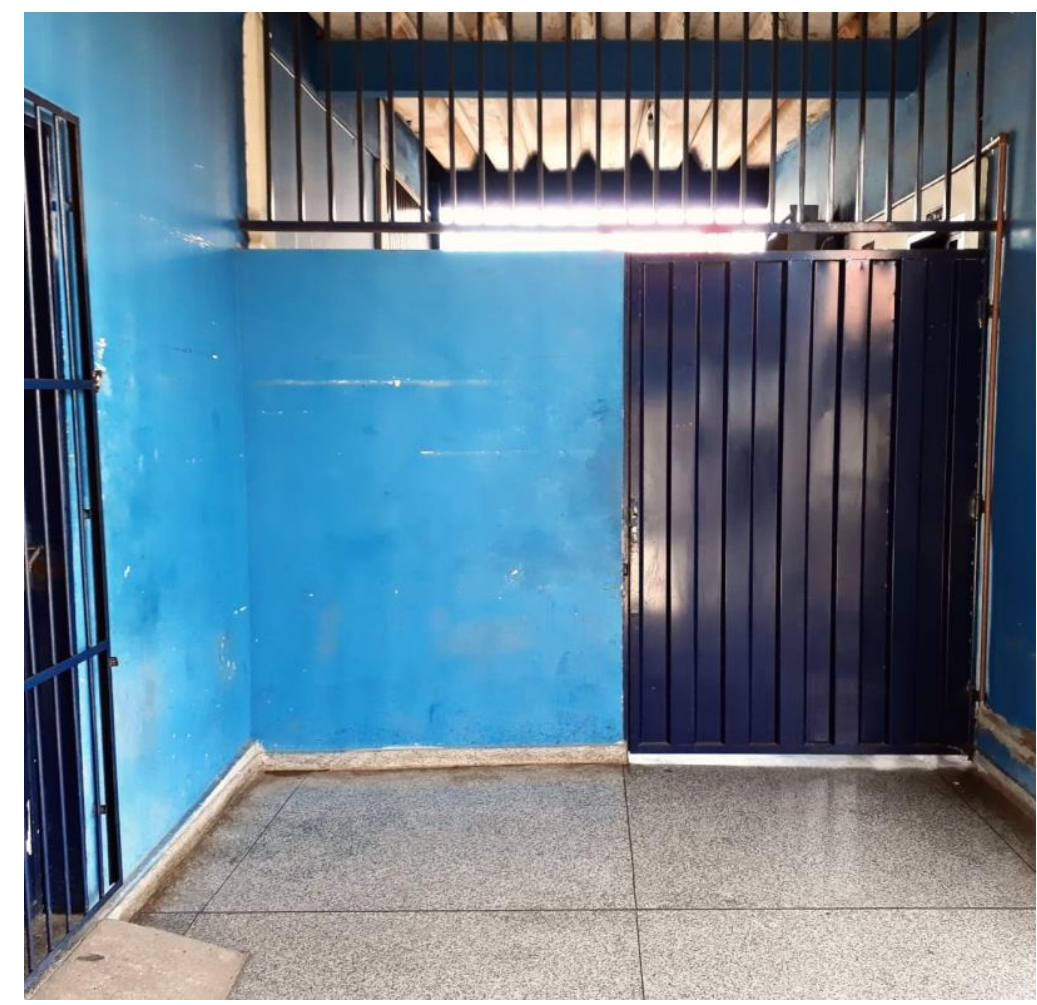

Imagem 14 - Acesso à secretaria da Escola Nelson Rodrigues com os portões fechados

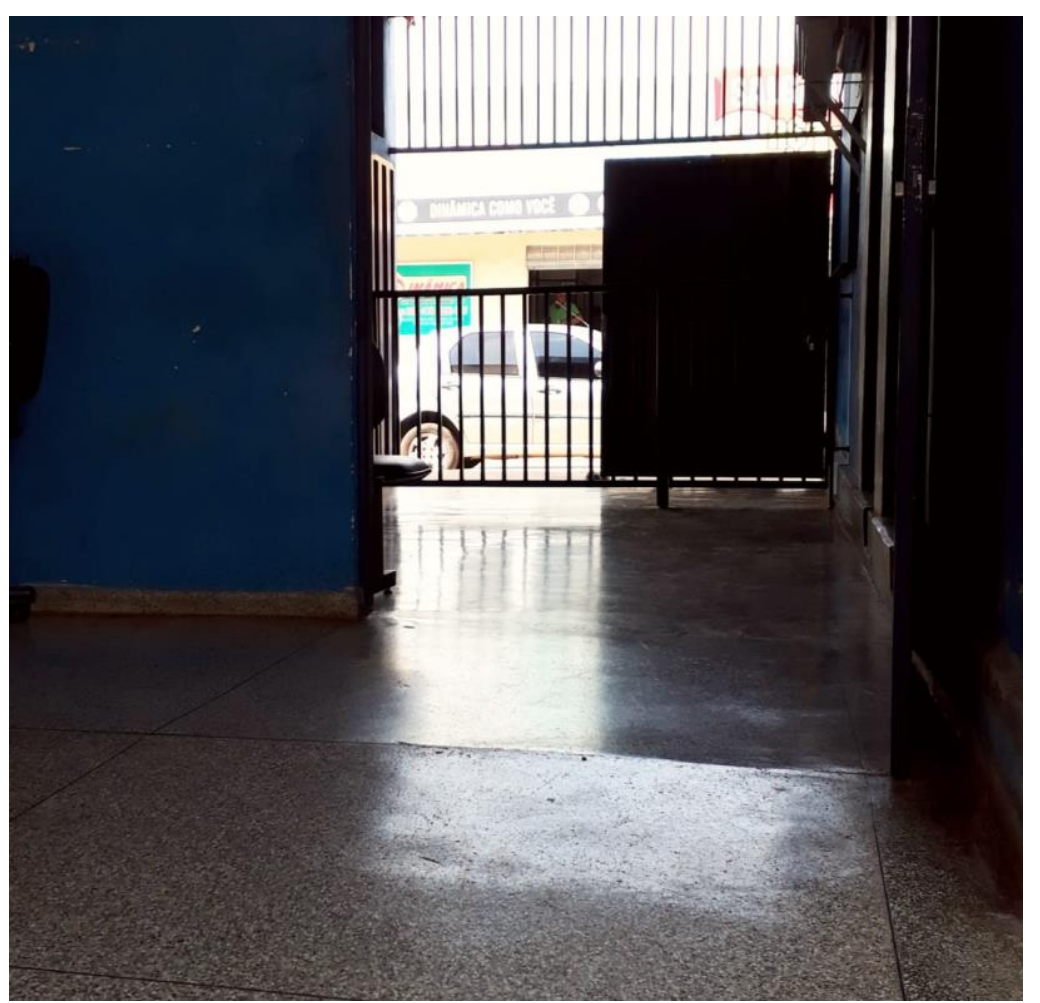

Imagem 15 - Acesso à secretaria da Escola Nelson Rodrigues com os portões abertos 


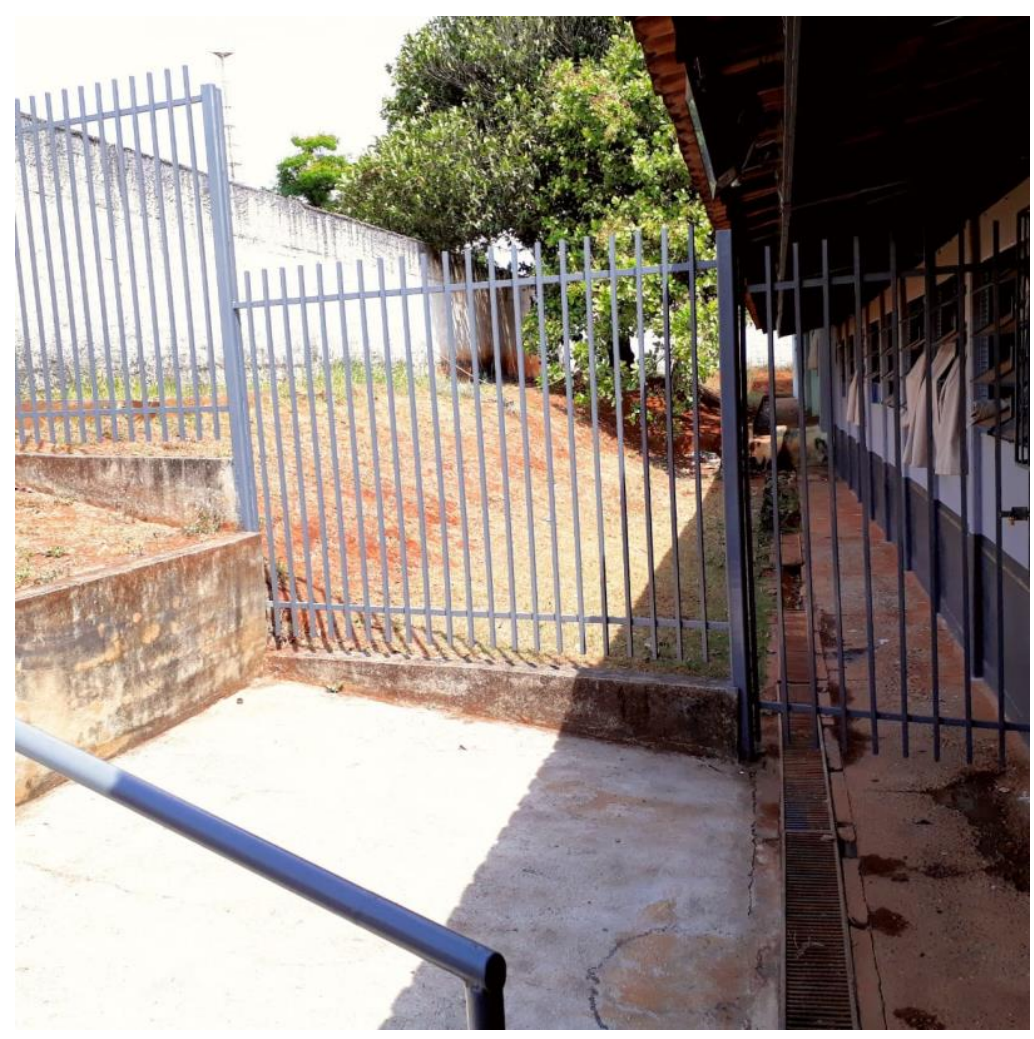

Imagem 16 - Acesso à secretaria da Escola Ariano Suassuna - A

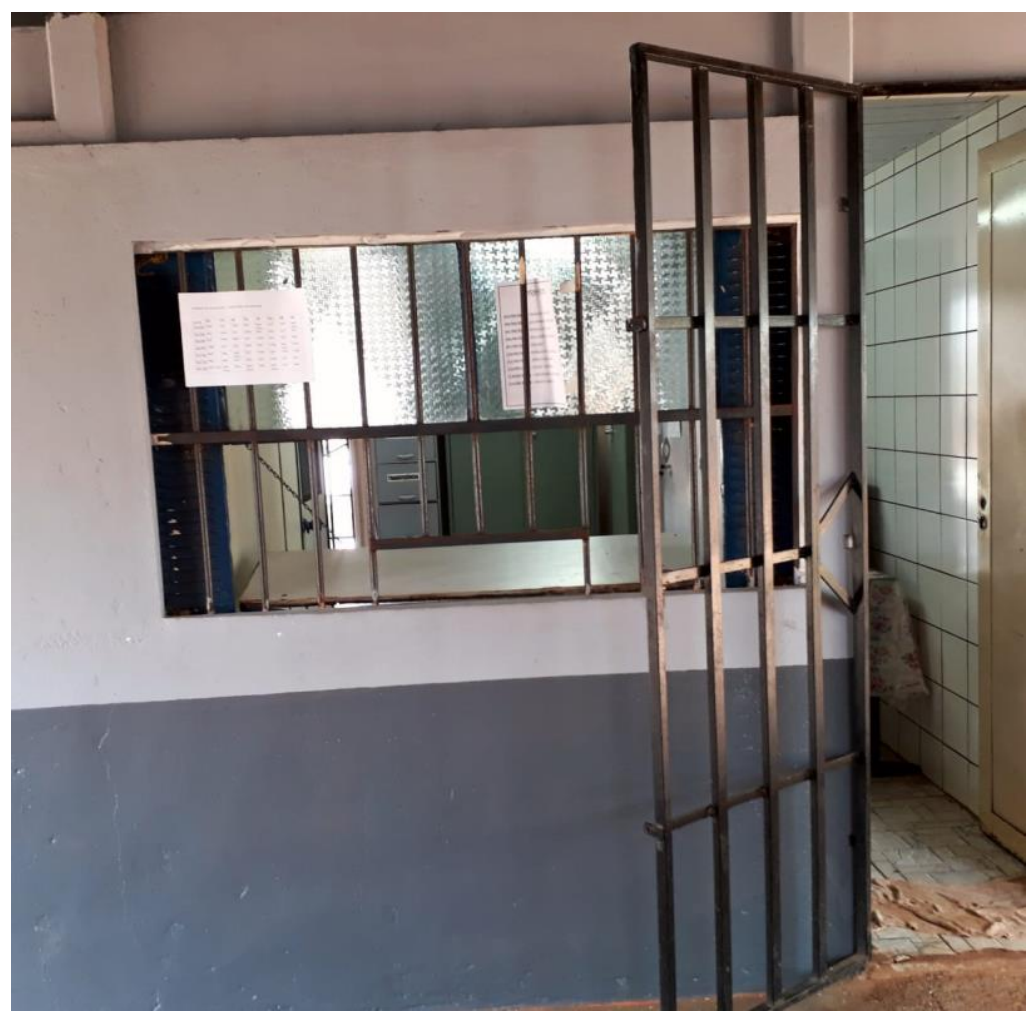

Imagem 17 - Acesso à secretaria da Escola Ariano Suassuna - B 

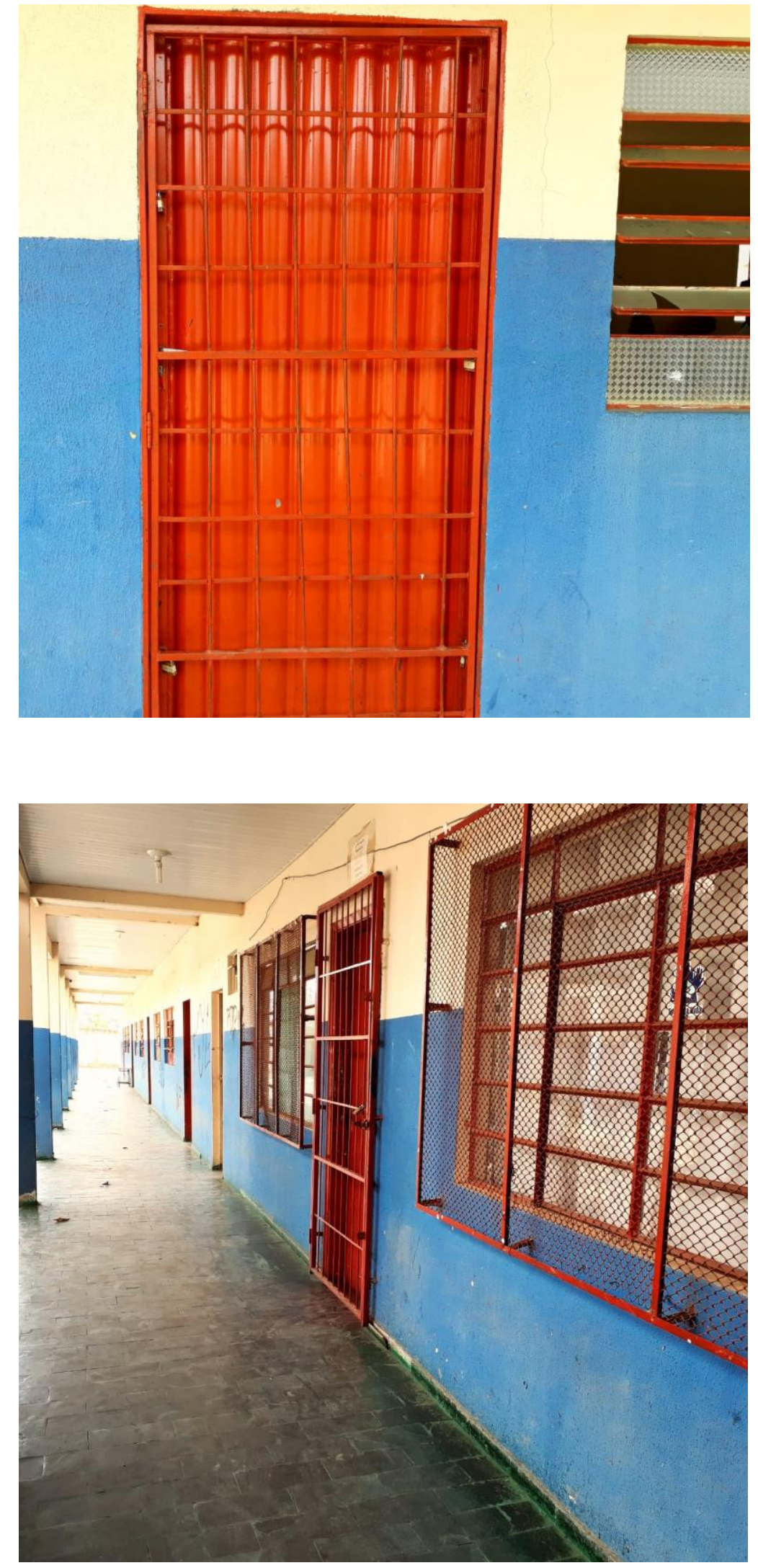

Imagem 18 - Porta da secretaria da Escola Martins Pena
Imagem 19 - Corredor da Escola Martins Pena 


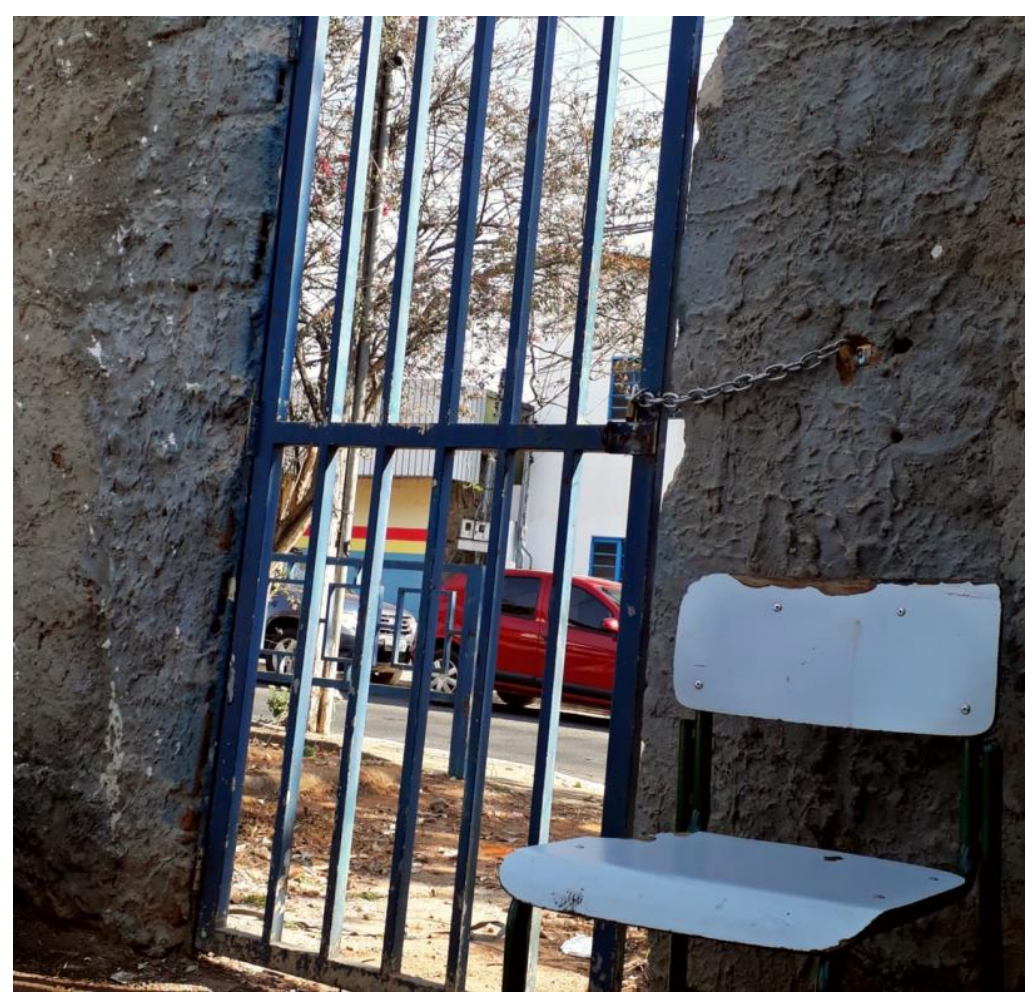

Imagem 20 - Um dos portões de entrada da Escola Maria Clara Machado

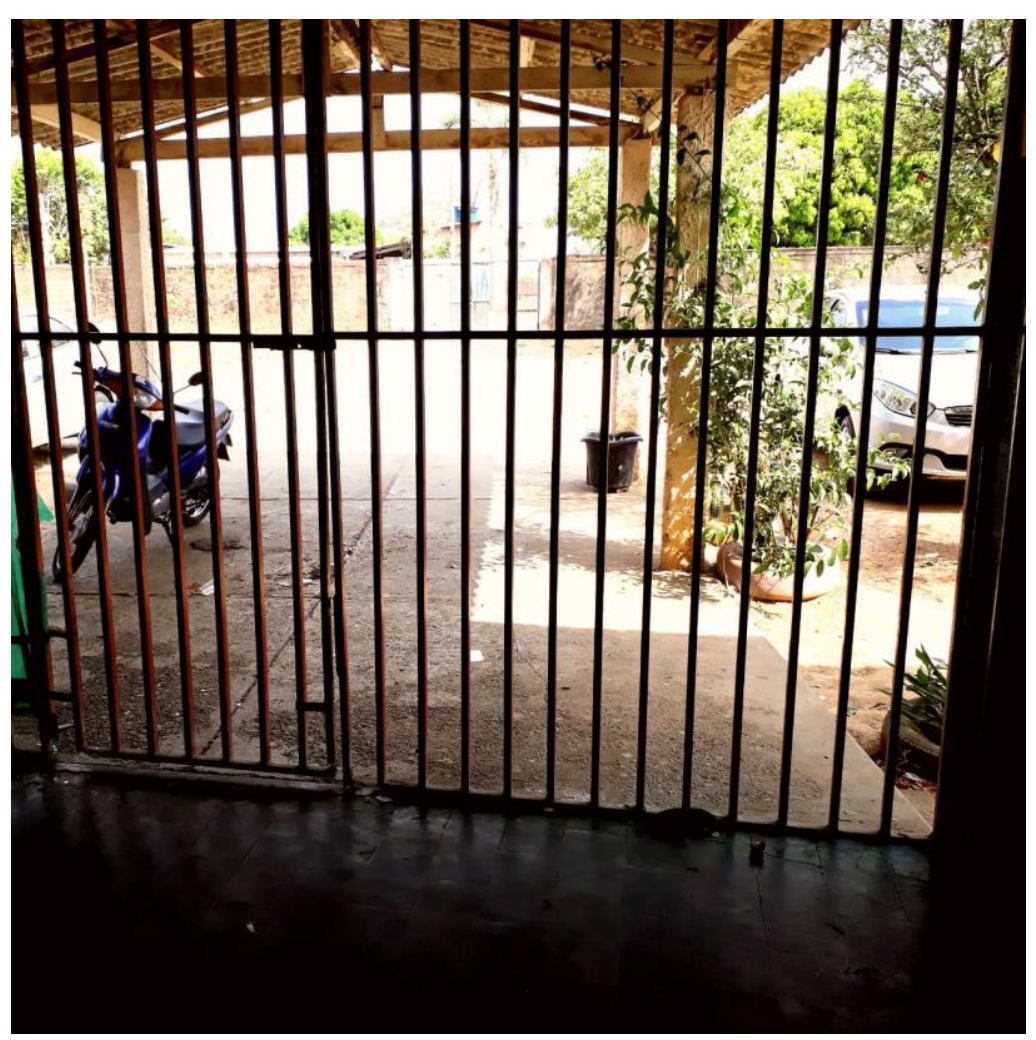

Imagem 21 - Portão de entrada da Escola Martins Pena 
De modo geral, essas barreiras de metal são erguidas não apenas para garantir a segurança das pessoas e dos equipamentos tecnológicos da escola. Elas são construídas também para promover um controle próprio dos espaços ocupados. Se uma sala estiver trancada, por exemplo, precisa-se pedir permissão para um dirigente superior. Inicia-se assim o sistema de controle escolar monitorando e acompanhando os corpos que entram, que permanecem e que saem.

No entanto, não podemos culpar as escolas pela construção das barreiras de ferro, pois, trata-se da apropriação de um sistema social de controle exercido por várias entidades, como por exemplo nas famílias, igrejas, comércio, no mundo do trabalho e nos momentos de lazer. Em estudo sobre a antropologia do corpo, Nicolino, Dias e Baptista (2014), apontam a criação da necessidade social permanente de monitorar e fiscalizar os corpos. Segundo os autores, nossa cultura considera válida a ideia de vigiar e punir os corpos constantemente em nome do respeito e da ordem social. De acordo com os autores:

\footnotetext{
O corpo, como propício a excessos, tem que ser policiado por tempo integral, vigiado, controlado e manipulado, dentro dessa moralidade social imposta. $\mathrm{Na}$ intenção de assegurar a "ordem social", o corpo se torna cada vez mais dependente de condutas punitivas e repressoras, segundo uma ordem social instaurada no corpo para este ser dócil e eficiente (NICOLINO; DIAS; BAPTISTA, 2014, p. 48).
}

Como se observa, os sistemas escolares apenas imitam os modelos representativos de segurança, controle e punição dos corpos. Trata-se de um modelo cultural bastante presente nas escolas públicas do país. Como foi explicado anteriormente, as escolas possuem um sistema próprio de segurança, controle e punição dos corpos com a finalidade de discipliná-los para o mundo da vida, do trabalho e das técnicas.

Nesse contexto, concordando com Foucault (1987), a escola torna-se um espaço especializado em fabricar sujeitos disciplinados, dóceis e capacitados para obedecer às normativas estabelecidas pelo sistema capitalista industrial. Desse modo, observa-se que os espaços escolares de muitas escolas limitam a aprendizagem corporal por negarem ou não possuírem uma estrutura física adequada para o desenvolvimento de novas experiências corporais. Sobre esse assunto, averiguamos os espaços escolares destinados a prática de atividades corporais de movimento, já que muitas escolas entendem a sala de aula como um lugar para o não movimento. 


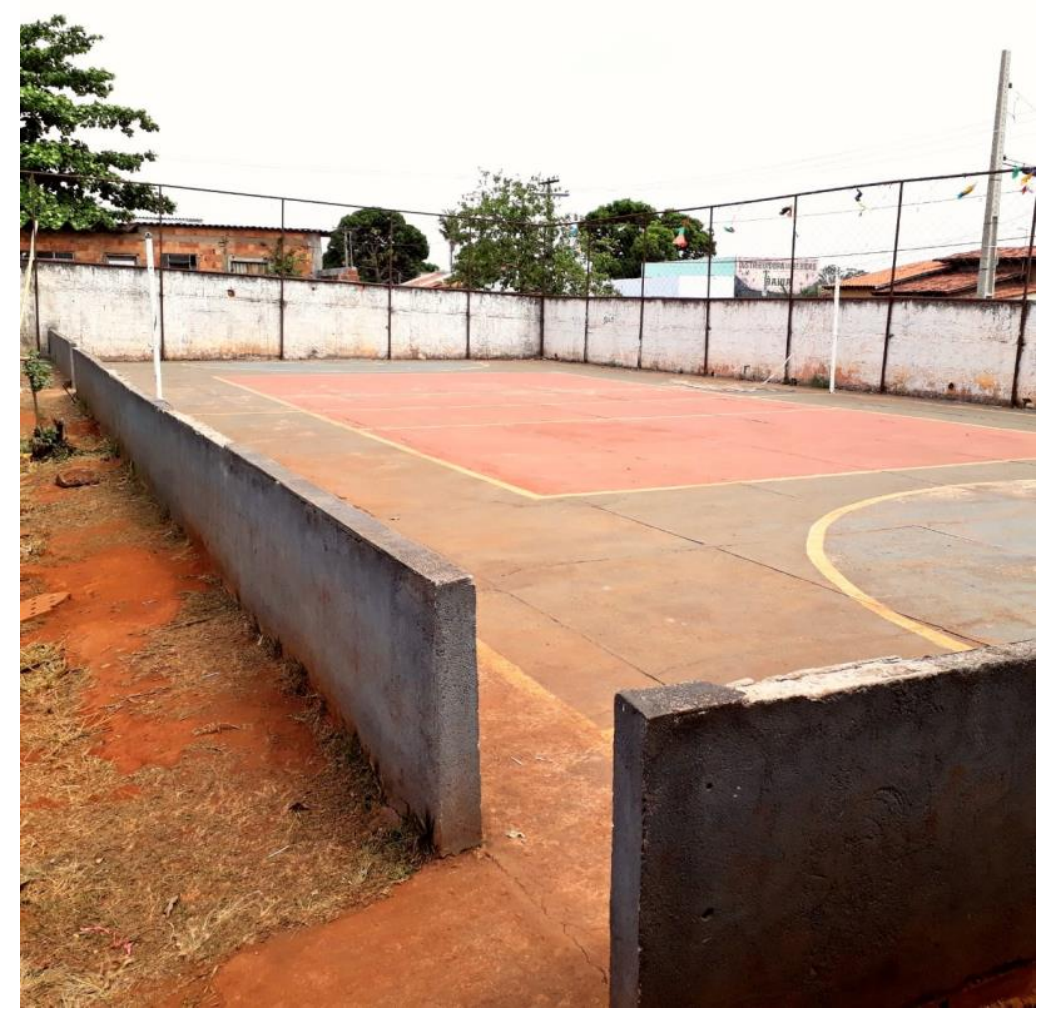

Imagem 22 - Quadra

de esportes e espaço de atividades físicas da

Escola Ariano Suassuna

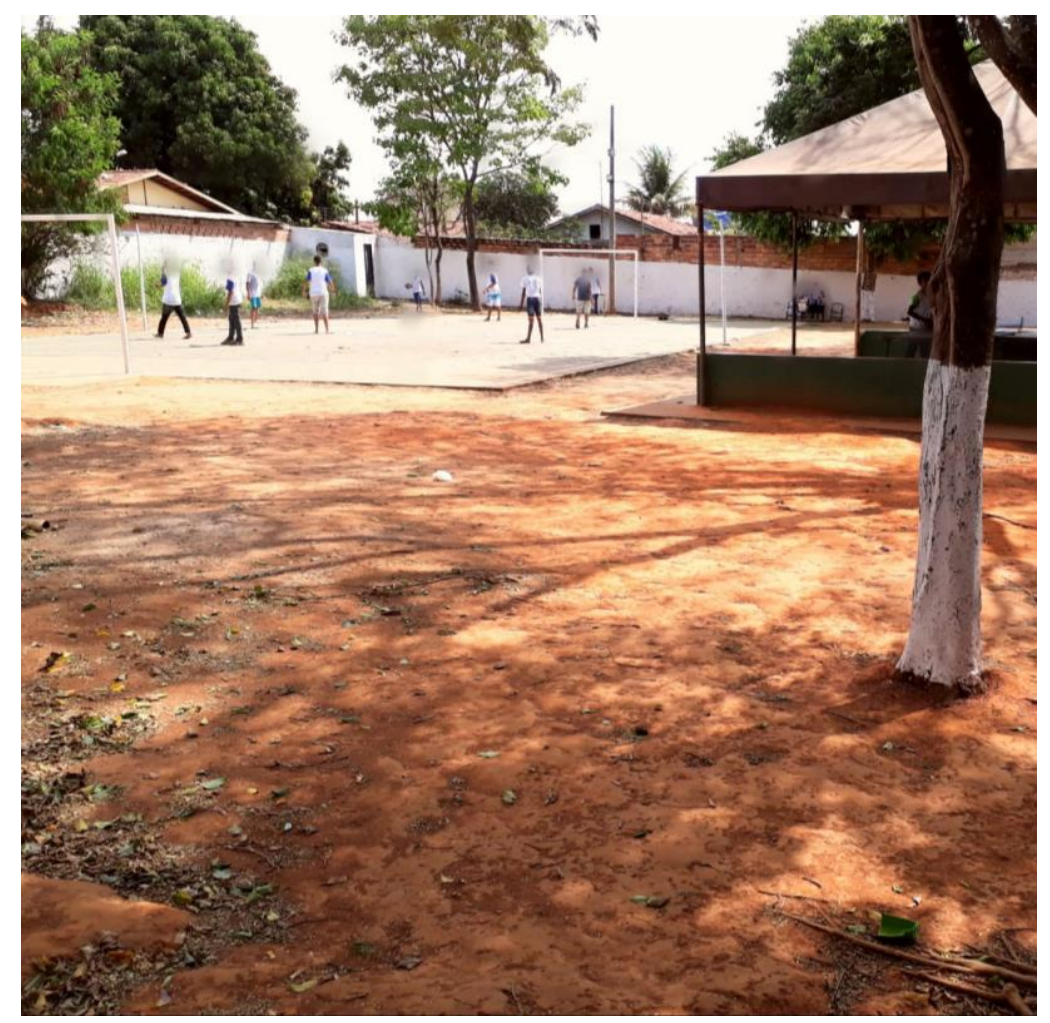

Imagem 23 - Espaço de convivência e prática de jogos da Escola Maria Clara Machado 


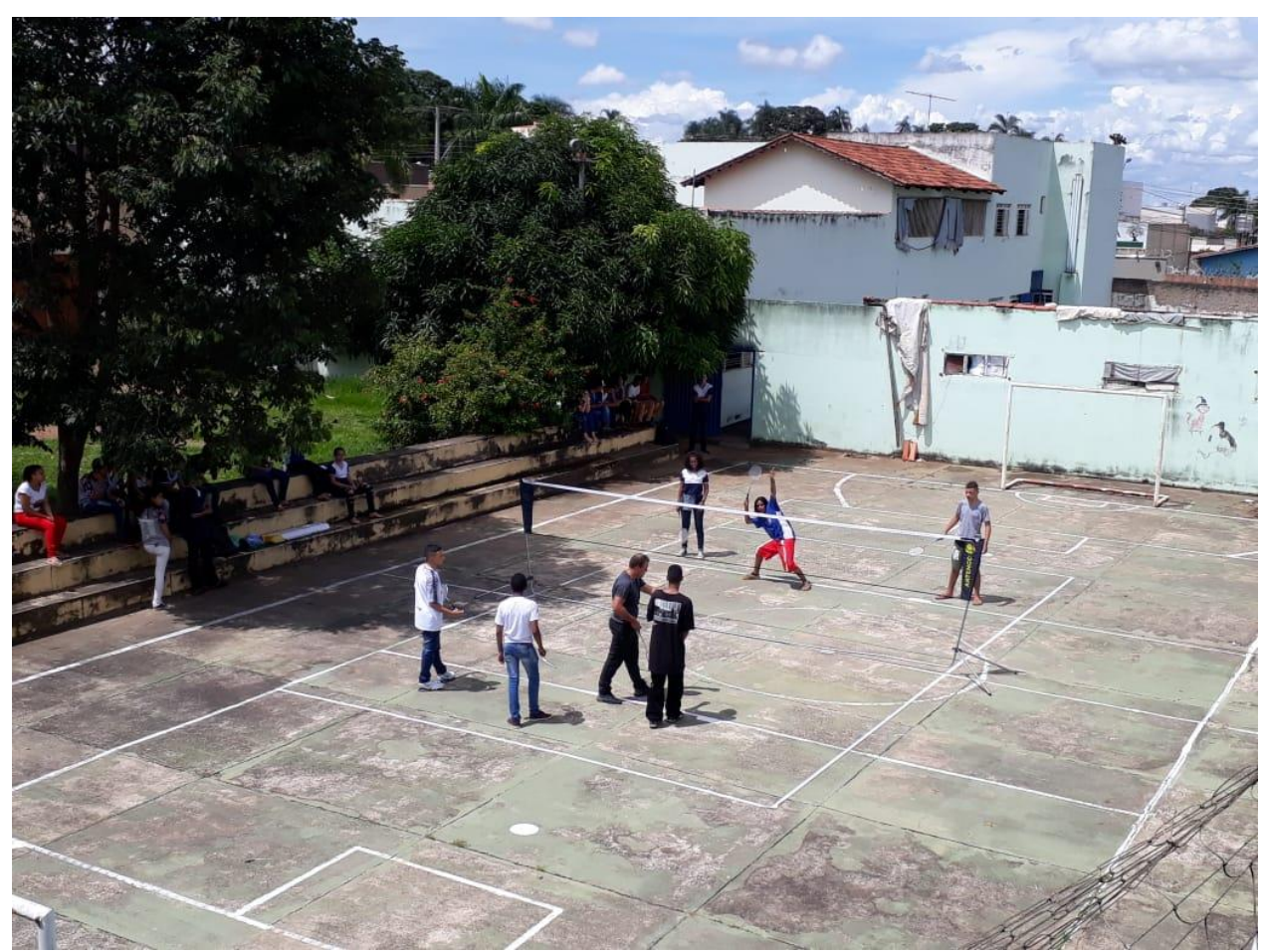

Imagem 24 - Quadra da Escola Nelson Rodrigues-2: espaço destinado a prática de atividades físicas e corporais

Por meio das imagens acima, podemos perceber uma grande carência nos espaços físicos destinados a atividades corporais nas escolas estaduais da região central da cidade de Aparecida de Goiânia-Go, confirmando, segundo Gaya (2006), a desvalorização do corpo nos processos de ensino e aprendizagem escolar. Nas imagens 22, 23 e 24, por exemplo, os estudantes ficam expostos às condições climáticas como o sol forte e a chuva para desenvolver algumas atividades corporais. De modo geral, essas carências impedem a prática de diferentes atividades corporais interessadas no desenvolvimento de novas sensibilidades.

A imagem 24 demonstra a Escola Martins Pena, na qual percebemos a ausência de um estudo aprofundado para a construção da quadra. Devido a isso, os raios do sol ocupam o espaço físico da quadra ao fim da tarde, assim como as gotas de água nos dias chuvosos. $\mathrm{Na}$ imagem 25, o corredor de acesso às salas de aula da Escola Nelson Rodrigues-1 é o único espaço físico destinados à prática de atividades corporais. Notadamente, a ausência de espaços adequados para a prática de atividades físicas, esportivas e de pesquisas corporais imprimem nos sujeitos a produção de movimentos corporais repetitivos. Assim, deve-se refletir sobre a real necessidade desses espaços não apenas para a prática de aulas de Educação Física, mas para o aprendizado como 
um todo, de modo a proporcionar ao corpo escolarizado condições para experienciar novos conhecimentos corporais.

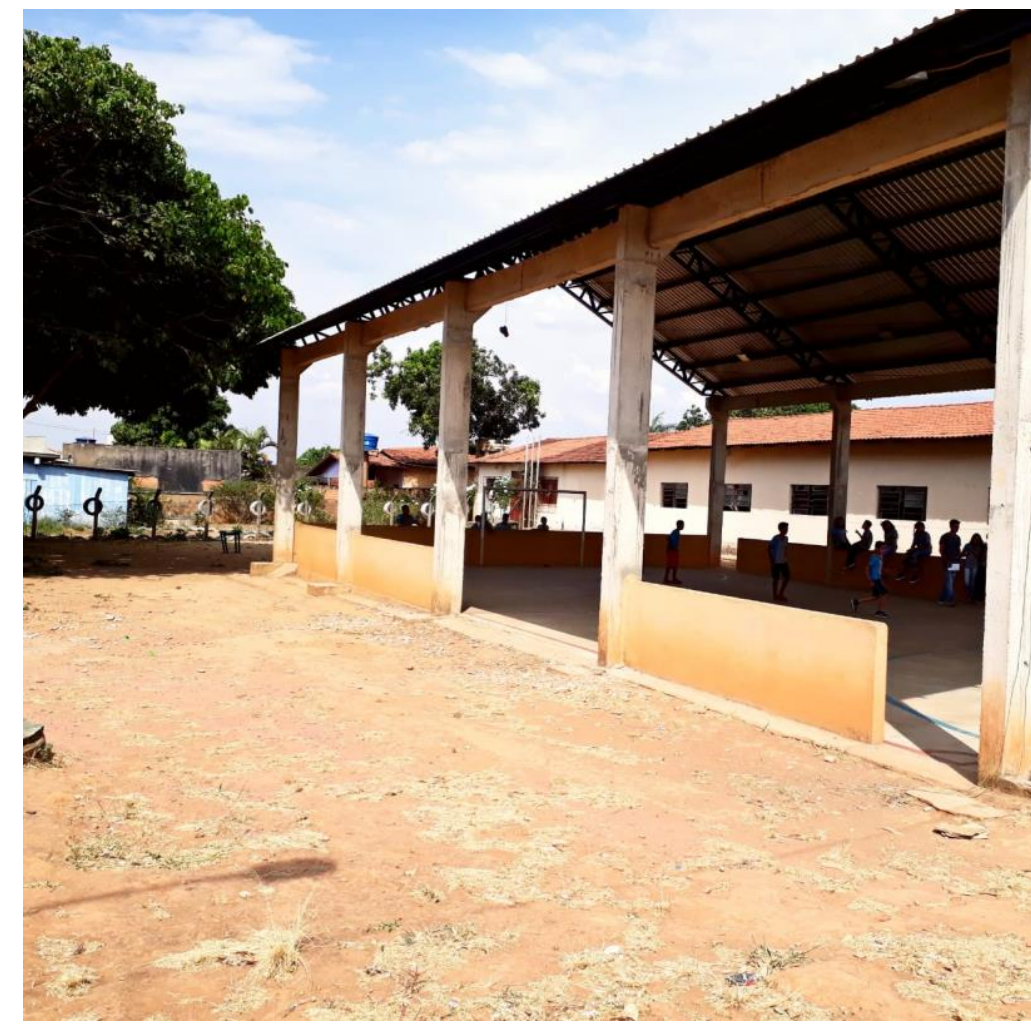

Imagem 25 - Quadra de esportes e espaço de atividades físicas da Escola Martins Pena

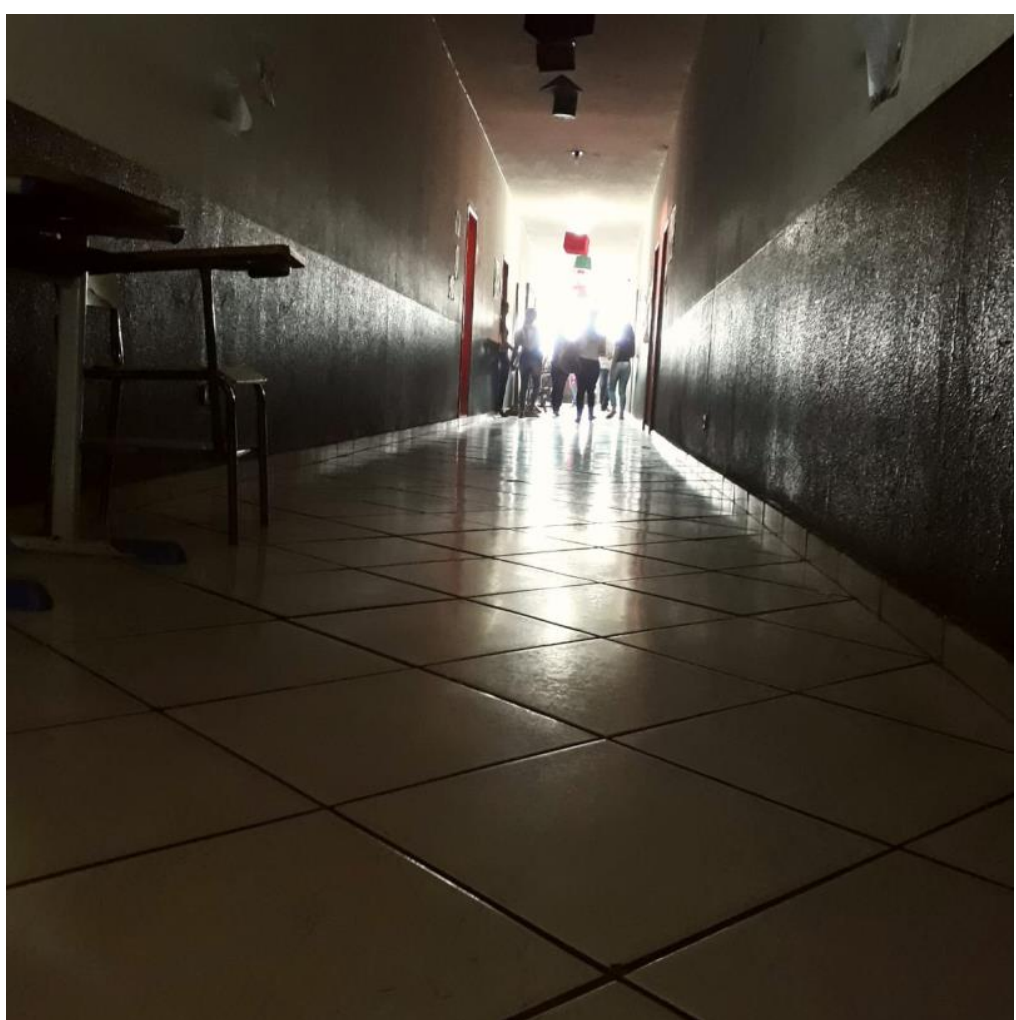

Imagem 26 - Espaço destinado a prática de esportes e atividades físicas da Escola Nelson Rodrigues-1 
Sobre esse assunto, de acordo com Le Breton (2012):

\begin{abstract}
Ao mesmo tempo em que se manifesta, a experiência corporal modela as percepções sensoriais pela integração de novas informações. [...] A percepção dos inúmeros estímulos que o corpo consegue recolher a cada instante é função do pertencimento social do ator e de seu modo particular de inserção no sistema cultural (LE BRETON, 2012, p.56).
\end{abstract}

Seguindo as reflexões do autor, toda a estrutura física escolar corrobora para uma construção social do corpo, suas simbologias, seus comportamentos e seus modos de agir. Portanto, reforçamos novamente a ideia de que a escola a partir de sua estrutura, suas regras e procedimentos fabricam sujeitos para atender a uma determinada lógica social. Desse modo, a ideia de manter estas estruturas menosprezadas demonstra de forma cortinada a negação escolar de novas experiências e aprendizagens corporais. Desse entendimento emerge a necessidade de pensarmos uma outra educação do corpo. Não uma educação do adestramento e da punição, mas uma educação para a autonomia de pensamentos e liberdade de expressão.

Consequentemente, nosso dever consistirá em analisar criticamente os usos que fazemos dos sistemas de controle e punição escolar. Acredito em novas releituras e usos desse sistema de forma a dar à escola uma identidade própria reconhecedora da diversidade, liberdade, alteridade, equidade e autonomia. Precisamos estar atento aos interesses impregnados nas normativas escolares advindas do interesse controlador do capital industrial.

\title{
3.5 - O tempo da aprendizagem corporal da escola
}

Notadamente, as escolas destinam grande parte do tempo para a inércia corporal por considerar esta condição como a mais apropriada para o ensino e aprendizagem. Assim, a aprendizagem corporal na escola é controlada pelo tempo, fragmentando-o em momentos específicos para a realização de atividades determinadas pela equipe docente. Hora para entrar, permanecer e sair. Hora para lanchar, fazer o dever, correr, brincar e se divertir.

Observando a primeira aula, assim que as crianças adentraram a Escola Nelson Rodrigues, a professora gastou poucos minutos para controlar a sala e professar as 
normativas. Passou a reinar a quietude corporal e o silêncio. O corpo escolarizado ${ }^{7}$ desapareceu, tornou-se invisível para atender a um modelo de educação controladora do corpo e dos movimentos. As expressões faciais dos estudantes nas aulas revelavam a angústia e a insatisfação da tortura do silêncio.

Geralmente, os estudantes sentem mais liberdade de movimento e expressão nas aulas de Educação Física e Artes. Nestas disciplinas, o corpo se faz mais presente, porém observam-se algumas continuidades do sistema operante em sala de aula. Os corpos são novamente ora regulados, ora desconsiderados.

A imagem a seguir demonstra a organização de uma partida de queimada durante uma aula de Educação Física na Escola Nelson Rodrigues. A professora solicitou a organização de uma fila para facilitar a comunicação sobre as normativas do jogo.

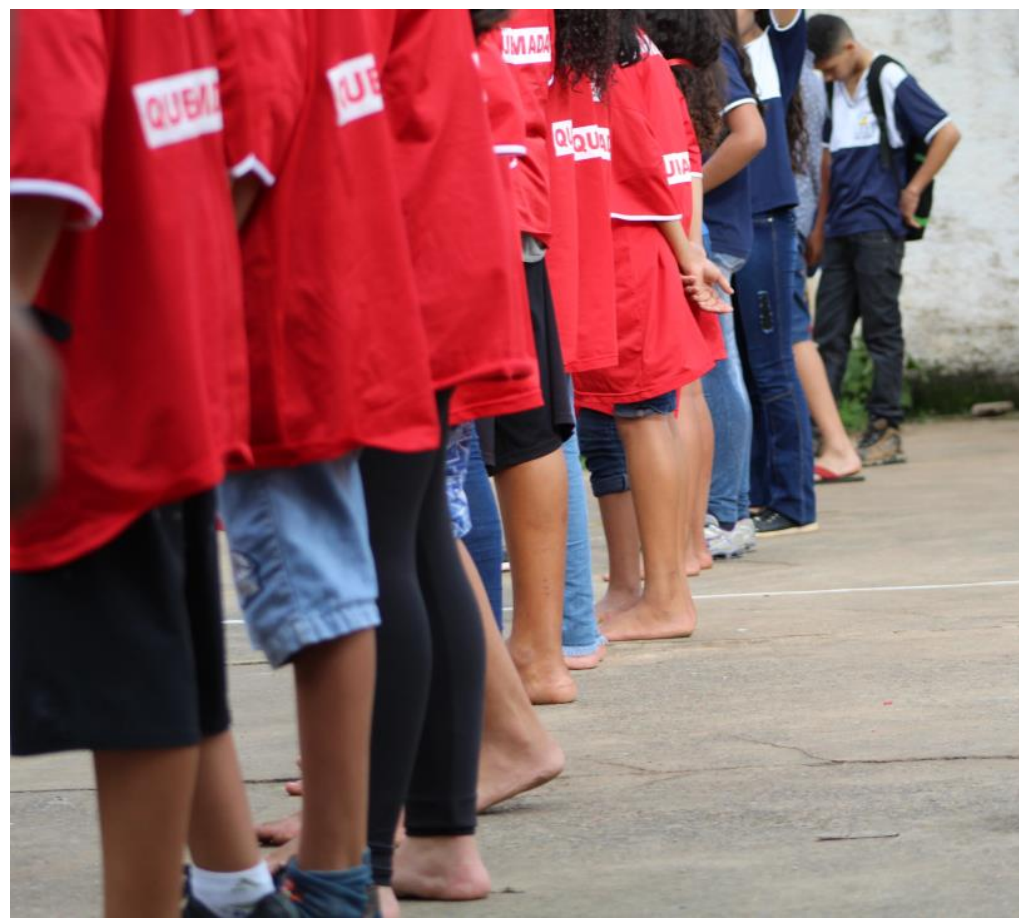

Imagem 27 - Estudantes da Escola Nelson Rodrigues aguardando o sinal da professora para iniciar uma partida de queimada

A imagem revela a forma habitual dos alunos de se organizarem para receber instruções. Os comportamentos dos alunos e da professora se assemelham a um modelo militar de ensino. Como prática aceita, os corpos se submeteram à obediência do tempo,

\footnotetext{
${ }^{7}$ O corpo escolarizado é entendido aqui como o corpo submetido aos espaços escolares, no qual deve obedecer as regras e imposições dos espaços escolares.
} 
sendo controlados pelo relógio e sirene da escola. É a sirene que determina o início e o término de uma aula.

A sirene é controlada pela coordenação. Logo, o tempo é igualmente controlado pelos superiores da escola. Os professores, por sua vez, não conseguem se organizar em sala de aula sem o toque da sirene.

Observando a questão do tempo na sala de aula verificou-se que as atividades realizadas em sala são também controladas pelo tempo. Os professores fracionam o tempo de suas aulas em tempos menores para a produção da aprendizagem. Trata-se de um tempo de produção, semelhante a um modelo industrial.

O corpo escolarizado é um operário da "fábrica de ensinar", ou seja, da escola. Por conseguinte, deve ser produtivo e não pode descansar em "serviço". O professor é uma espécie de "encarregado da fábrica". É o responsável por atribuir as tarefas e os tempos disponíveis para o cumprimento de cada atividade. Os corpos não produtivos serão penalizados, podendo inclusive sofrer uma "demissão" que, nos termos escolares, significa a transferência pedagógica de unidade escolar conforme o Regimento Escolar.

\section{6 - O controle das vestimentas e adereços corporais}

Para a escola não basta apenas controlar os corpos, seus movimentos e suas sensibilidades. É preciso controlar também aquilo que o corpo carrega consigo, no caso as vestimentas e os adereços. Em nome da organização e da ordem, os estudantes devem entrar na escola usando o uniforme escolar. É uma das várias maneiras de padronizar os corpos, como se todos fossem iguais e se expressassem de uma maneira única.

$\mathrm{Na}$ Escola Maria Clara Machado, por exemplo, cartazes informativos foram fixados nas dependências da escola para alertar os estudantes sobre algumas condições de vestimentas para os seus corpos. Conforme a imagem a seguir, são permitidos no espaço escolar apenas bermudas e saias com comprimentos abaixo do joelho.

Do mesmo modo, o cartaz informa sobre a proibição de bonés, gorros e similares. É informado ainda sobre a proibição do uso de cigarros e seus derivados nas dependências da escola. Por fim, o cartaz instrui sobre a ocupação do espaço do corredor apenas em casos autorizados pela coordenação pedagógica. Vejamos a seguir algumas imagens da Escola Maria Clara Machado. 


\section{ATENÇÃO ALUNOS}

\section{É extremamente proibido:}

- Usar roupas curtas ou decotadas;

- Usar boné, toucas ou similares;

- Fumar nas dependências da escola;

- Perambular pelo corredor sem autorização.

À coordenação
Imagem 28 - Cartaz informativo fixado no mural de avisos da Escola Maria

Clara Machado

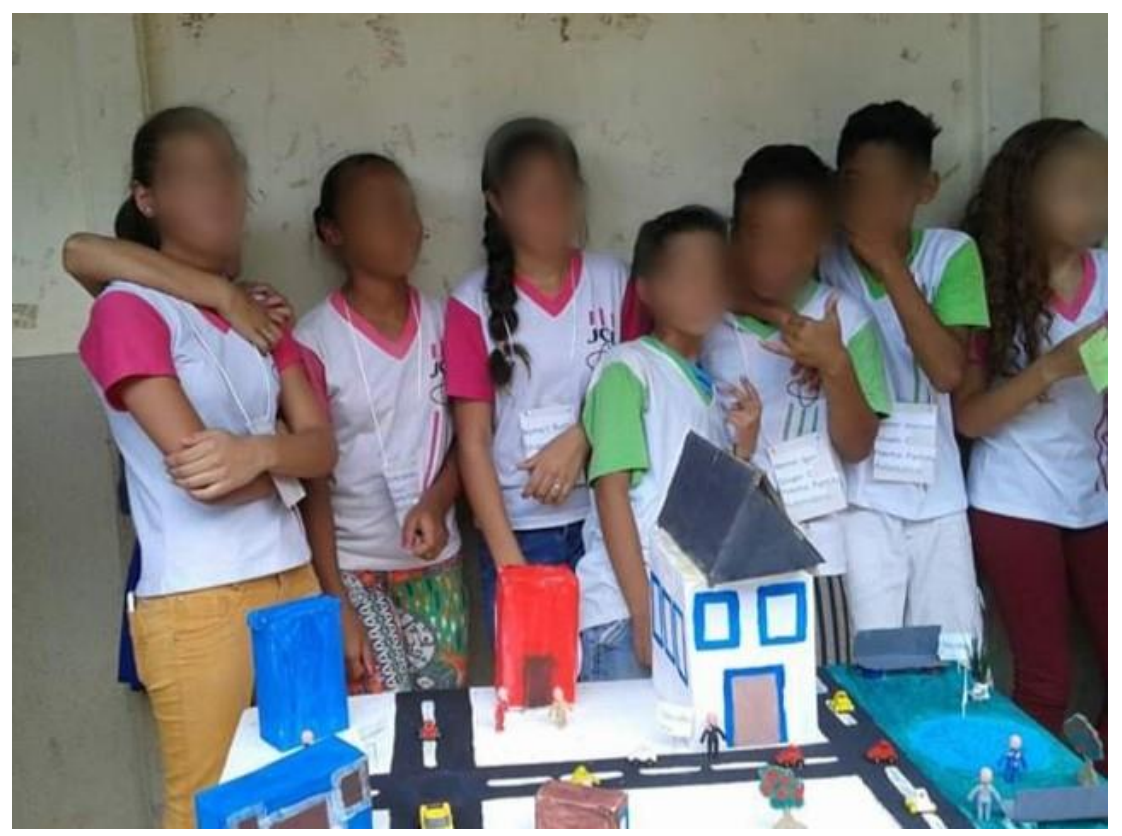

Imagem 29 - Uniforme sexista adotado pela Escola Maria Clara Machado

Como se observa, de modo geral, tudo dentro da escola é controlado: a forma como os corpos se vestem, se movimentam, se expressam e se relacionam. Sem dúvidas, é a real preparação para a obediência e civilidade no mundo contemporâneo marcado pelo conservadorismo. O simples ato de utilizar o uniforme escolar representa uma preparação para o mercado de trabalho, momento no qual os estudantes trabalhadores utilizarão uma roupa padronizada com a estampa da empresa. Mais do 
que isso, a Imagem 28 anuncia o binarismo de gênero presente na Escola Maria Clara Machado, no qual as meninas usam uniforme com detalhes de cor rosa e os meninos de cor verde. Desse modo, a escola mais uma vez revela a sua predisposição para a preparação de corpos para o atendimento das exigências do capital industrial e da heteronormatividade.

\section{7 - Corpos em comunicação: o ver e o ser visto}

Nosso corpo é comunicação. Ele é dotado de uma linguagem própria denominada por muitos teóricos de linguagem corporal, como Le Breton (2012) por exemplo. Nossos gestos, movimentos e comportamento social expressam ao mundo os nossos sentimos, pensamentos e pretensões. As artes, por exemplo, se mostram como técnicas de criação interessadas em despertar novas comunicações sensitivas. É por meio dessa área do saber, por exemplo, que muitos de nós conseguimos demonstrar sentimentos, ideias e pretensões ocultadas pelos modelos carcerários de educação do corpo.

Muitas vezes, encontramos a liberdade de pensamento e expressão nas várias formas de produção de arte, sejam elas visuais, cênicas ou sonoras. Assim, de modo geral, pode-se afirmar que a nossa comunicação com o mundo acontece de diferentes maneiras e não se limita a uma comunicação meramente técnica e verbal. Sobre esse assunto, o teatrólogo Augusto Boal mencionou o pensador Voltaire e prescreveu que "a palavra foi dada ao homem para disfarçar o seu pensamento" (BOAL, 2009, p. 65). Isso demonstra o quanto a nossa comunicação pode ser limitada quando fazemos uso apenas das palavras. Ainda segundo Boal (2009):

[...] pensar é sobretudo sentir, e que só a sensibilidade nos faz saber que existimos, mas afirmo que o ato de pensar com palavras tem início nas sensações e, sem elas, não existiria, embora delas se desprenda e se autonomize até à sua mais total abstração. (BOAL, 2009, p. 27).

Pensando nisso, partimos para uma observação acerca das pichações presente nas dependências das escolas. De modo geral, muitos professores e diretores escolares criminalizam as pichações dos alunos no ambiente escolar, relacionando-as a processos de vandalismo, conforme comprova a ata escolar a seguir. 


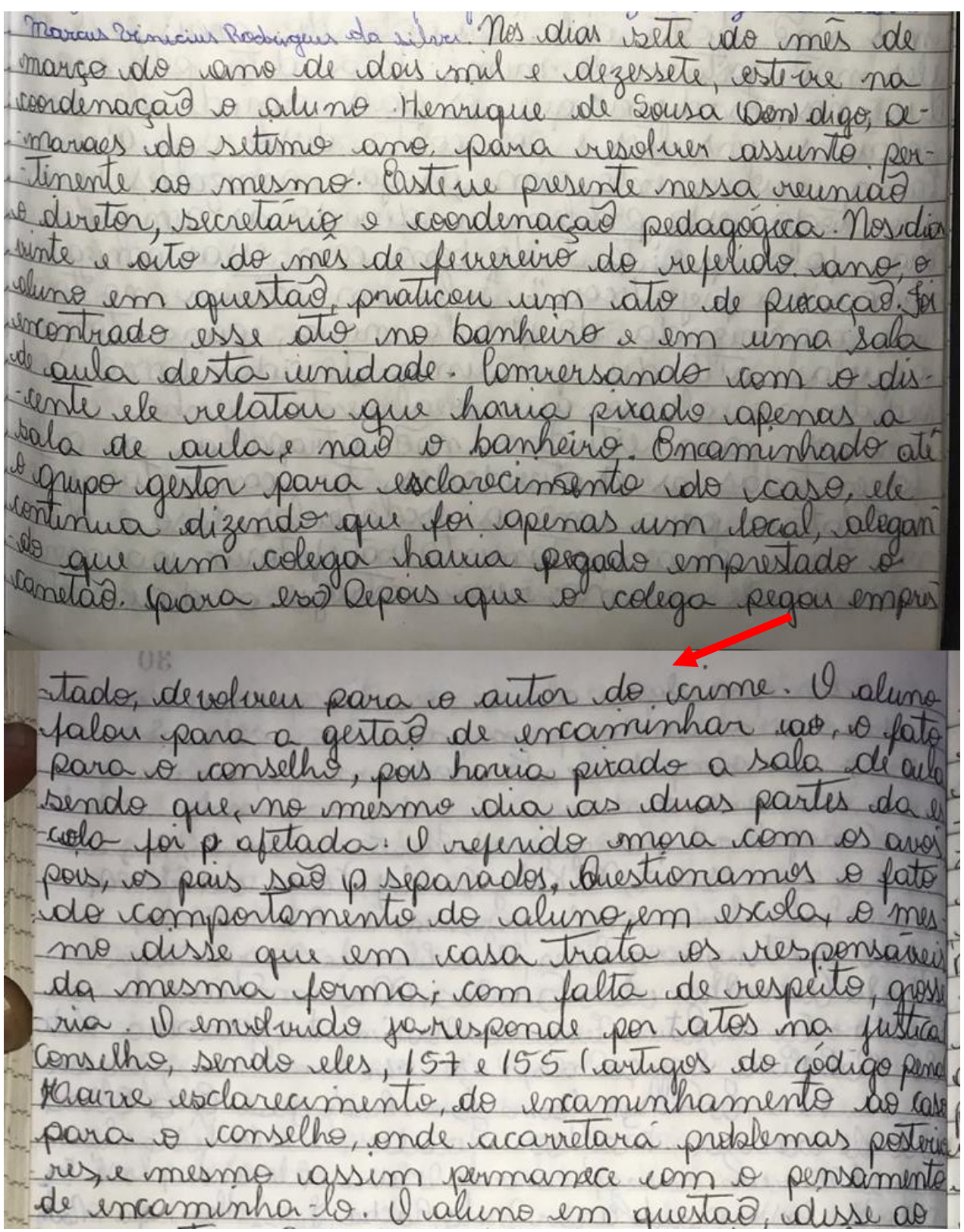

Imagem 30 - Relatório da coordenação da Escola

Nelson Rodrigues acerca de uma pichação realizada por um aluno

Nesta pesquisa, parto da concepção desenvolvida por Vaz (2013) para conceber a pichação. Segundo este autor, a pichação deve ser entendida como:

Um poder de resistência. E, sendo assim, por que não trabalhar a pichação na escola? Afinal, o que seria da educação se não nos dispuséssemos a produzir algumas pichações, algumas perturbações para com elas subvertermos algumas normalizações que nos imobilizam? (VAZ, 2013, p.87). 
As proposições de Vaz (2013) são pertinentes porque demonstram que as mensagens, desenhos e siglas manifestados nas paredes das salas de aula tem muito a dizer sobre o corpo na escola e suas manifestações expressivas. Ainda de acordo com Vaz (2013):

\begin{abstract}
Pichação é aquilo que escapa, que quer ser visto, mas que não se pretende eterno. Sejam manifestações individualistas, românticas, coletivas ou revolucionárias, elas se integram à paisagem, falam a partir da paisagem, mas querem ser mais do que isso. Querem sempre estar à margem, porque assim serão notadas. Formalmente se destacam pela repetição, pela demarcação anônima de territórios (VAZ, 2013, p.92).
\end{abstract}

De acordo com Vaz (2013), há diferentes motivos justificadores para as pichações. Um desses motivos, a demarcação anônima de territórios, é a forma mais comum encontrada nos muros e dependências da escola, onde os sujeitos ignorados sentem a necessidade de afirmarem o seu pertencimento naquele espaço. Em outras palavras, as pichações advêm de corpos ignorados pelos processos educacionais e que, por isso, necessitam imprimir suas marcas de pertencimento nos espaços da escola.

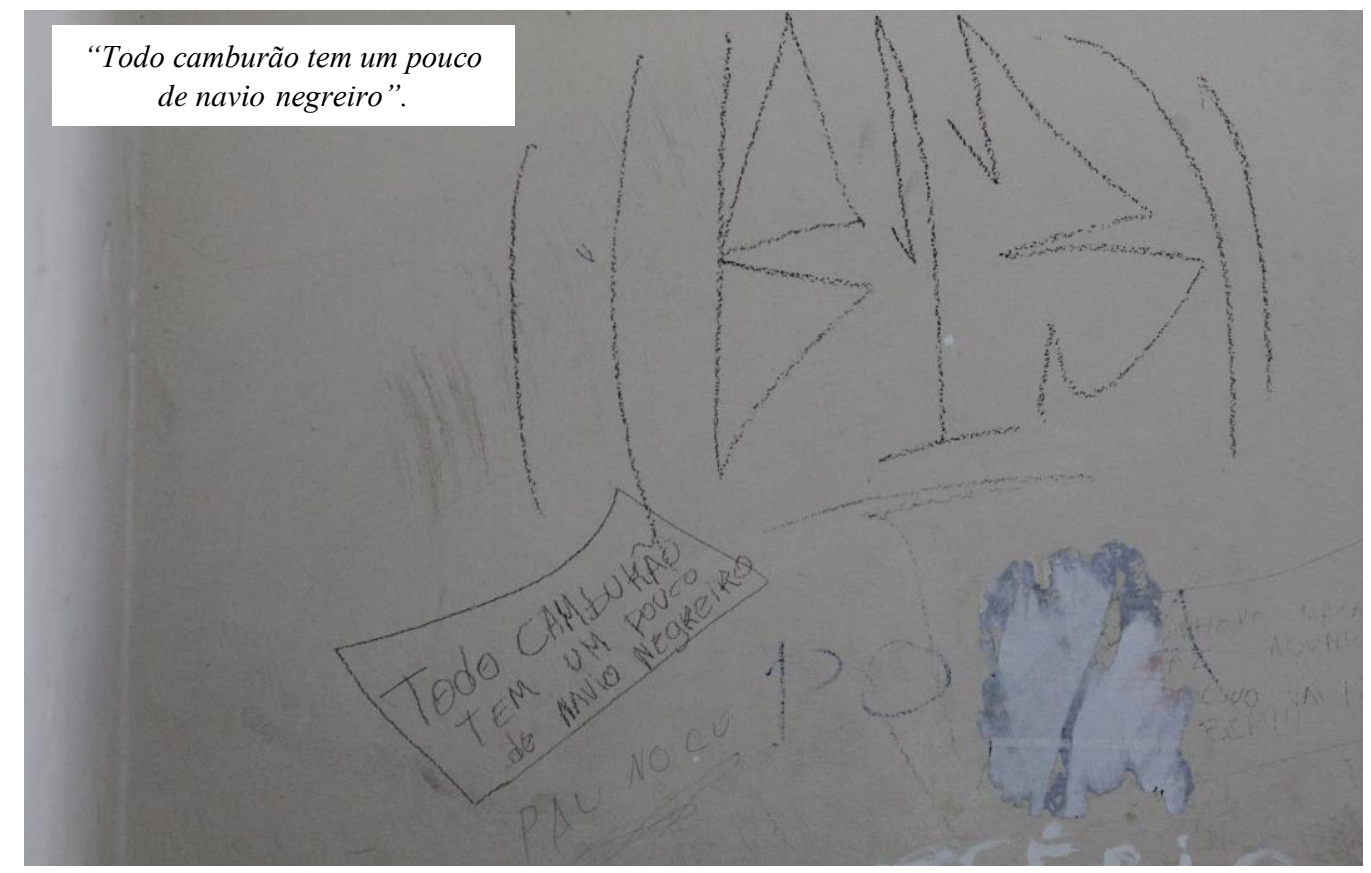

Imagem 31 - Pichação impressa na parede de uma das salas da Escola Nelson Rodrigues

Geralmente, isso acontece porque a escola, em muitos processos, padroniza seus procedimentos de ensino e aprendizagem corporal. Conforme Wainer (2005): 
Toda arte que se preze tem de incomodar, causar no espectador algum tipo de reação à qual ele não está acostumado. A pichação é um bom exemplo de como cumprir bem este papel (WAINER, 2005, p.98).

Ao considerarmos as pichações escolares como arte, conforme salientou Wainer (2005), reafirmamos a predisposição das artes para o rompimento de ideias e estereótipos padronizados. Toda arte tem um propósito e as pichações enquanto arte tem o propósito de mostrar o que não vemos, de cultuar o enfrentamento e de apresentar as inconveniências geradas pela estrutura social vigente. Desse modo, as pichações são manifestações artísticas que revelam as insatisfações dos corpos escolarizados e a tortura provocada pelas caixinhas de enquadramento social. Conforme Barchi (2007), as pichações devem ser vistas como intervenção política, pois:

\begin{abstract}
Os pichadores, ao agir de forma descentralizada, nômade, de certa forma ocultando sua identidade, o fazem intencionalmente ou não, como forma de revolta e resistência, seja contra a sociedade que os torna marginais e criminosos, seja contra a escola que não os retribui em seus desejos e necessidades. Tornam-se assustadoras possivelmente por sua organização não estrutural e não hierárquica. Nesse formato não centralizado, único e desestruturado, fornece novas possibilidades políticas de se pensar ações e reivindicações, pelo seu próprio modo de existência, de não se adequar aos corpos monolíticos estruturais (BARCHI, 2007, p.04).
\end{abstract}

As ideias de Barchi (2007) corroboram para refletir sobre a educação do corpo para a obediência e atendimento às normativas sociais desenvolvidas na maioria das escolas do país. Deve-se promover uma educação de forma a contribuir para a construção de um corpo preparado para o enfrentamento e para a busca da transformação social. Nesse sentido, é preciso questionar quem são estes corpos pichadores também, ou seja, os artistas geradores de incômodos sociais. Reis, Araujo e Torres (2018) realizaram um estudo sobre esse assunto. Segundo os autores:

Por outro lado, existem ali também corpos pichadores, que marcam as paredes do colégio de diferentes maneiras: poema, frase de amor ou autoajuda, letra de música, desenho, palavrão, reinvindicação, assinatura, sigla de grupos feita para chamar atenção, ou passar o tempo, mostrar poder, ou protestar, ou simplesmente se divertir. Esses corpos também são marcados pelas paredes pichadas, criando outro tipo de relação com aqueles espaços, um atravessamento de memórias sobre as circunstâncias nas quais as pichações foram feitas. [...] Nesse sentido, as pichações no espaço escolar instauram um campo inevitavelmente político (REIS, ARAUJO e TORRES, 2018, p.115, grifo nosso). 
Conforme as ideias dos autores, as pichações no espaço escolar apresentam um campo político de debate, discussão e reformulação de conceitos. As pichações não estão na escola por acaso, há uma lógica de operacionalização que as sustentam e reforçam a necessidade de comunicar aquilo que a escola desconsidera e julga inútil.

Era um país muito engraçado, não tinha escola, só tinha estádio

Ninguém podia protesta não, porque a PM sentava a mão...".

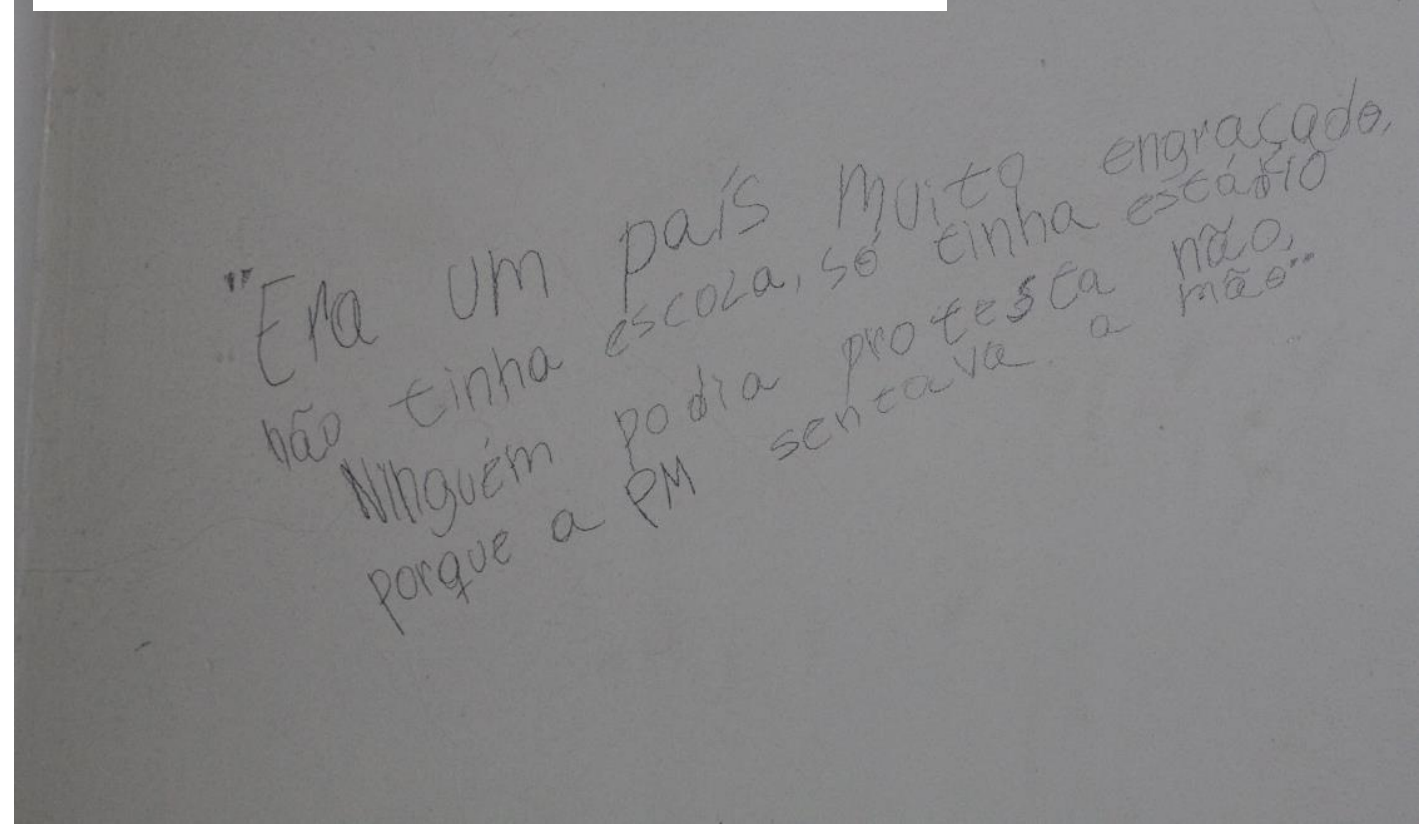

Imagem 32 - Pichação impressa na parede de uma das salas da Escola Nelson Rodrigues

Observando as dependências internas da Escola Nelson Rodrigues, por exemplo, nos deparamos com pichações de diferentes naturezas. Nas salas de aula, há um numeroso volume de mensagens impressas nas paredes e mobiliários. São constituídas, em sua maioria, de recados de amor, palavrões, frases com conotação sexual, desenhos diversos, atritos e reivindicações comunitárias, mensagens sobre times de futebol, siglas representando demarcação de territórios, dentre outros.

A partir das pichações nas paredes da Escola Nelson Rodrigues, percebemos uma série de frases, palavras, siglas, códigos e desenhos que estabelecem comunicações entre os estudantes da escola. Essas pichações assumem uma condição espaço-temporal marcada por uma linguagem própria dos alunos. As inúmeras frases carregam diversos significados e são facilmente reconhecidas pelos alunos. 


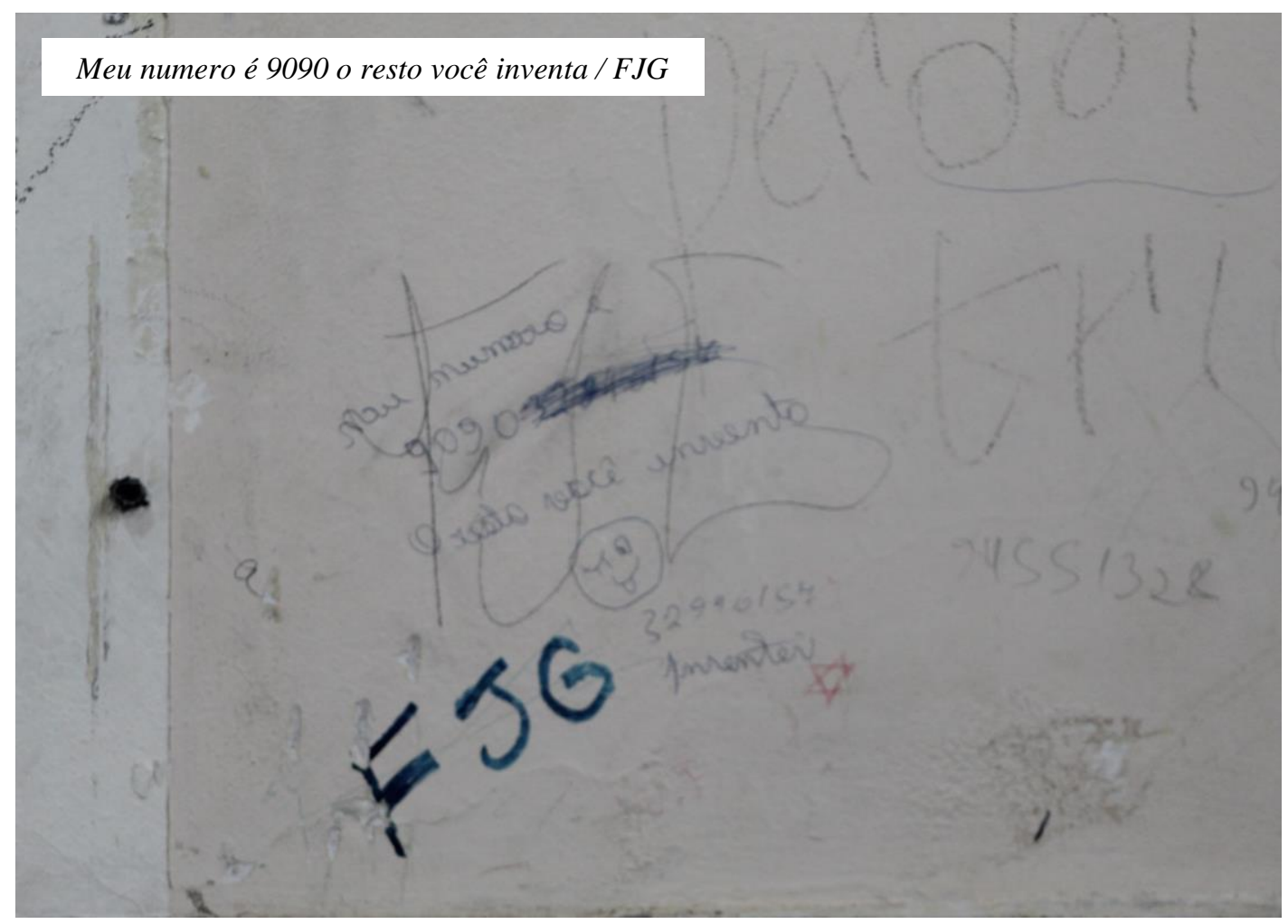

Imagem 33 - Pichação impressa na parede de uma das salas da Escola Nelson Rodrigues

Algumas dessas siglas, como por exemplo a sigla FJG apresentada na Imagem 33, não está apenas nas paredes e muros da escola. Está nas ruas, viadutos, nas poltronas dos ônibus e na comunidade em geral. Segundo alguns estudantes da Escola Nelson Rodrigues, a referida sigla significa Força Jovem Goiás e simboliza um grupo de torcida organizada de futebol do Estado de Goiás. De modo geral, conforme aponta Garcez (2000):

Enquanto tem espaço em branco, têm sempre novos ou repetidos desenhos a nos encarar. O que falam? O que calam? Que filosofia de mundo querem nos contar? Será que essas pichações - bem desenhadas, bem contornadas ou simples garranchos - dizem algo mais que simplesmente o sujar das paredes? E quem as picha? E o que querem e o que esperam delas? (GARCEZ, 2000, p.28).

Garcez (2000) apresenta provocações profundas sobre o real significado das pichações nas paredes e mobílias da escola. Com isso, afirma-se que os corpos escolarizados manifestam essas atitudes porque se sentem presos a um sistema disciplinador e hierárquico de educação do corpo, restando poucos lugares para 
expressar suas identidades, ideias e valores construídos pelos grupos aos quais pertencem. Ainda segundo Garcez (2000):

As pichações devem ser vistas não só como forma de transgressão aos valores, regras e normas escolares, mas também como forma de escapar ao mundo socialmente estabelecido, ao mesmo tempo que impõe um mundo próprio que dá significado a sua existência (GARCEZ, 2000, p.160)

Em concordância com os apontamentos realizados por Garcez (2000), parece haver dentro da escola um sistema operante que não permite aos corpos a expressão livre de suas ideias, desejos e identidades. Todo esse trajeto de negação ao corpo escolarizado parece resultar em novas necessidades humanas de comunicação. São desejos ligados ao ato de ver, de ser visto e de ser lembrado.

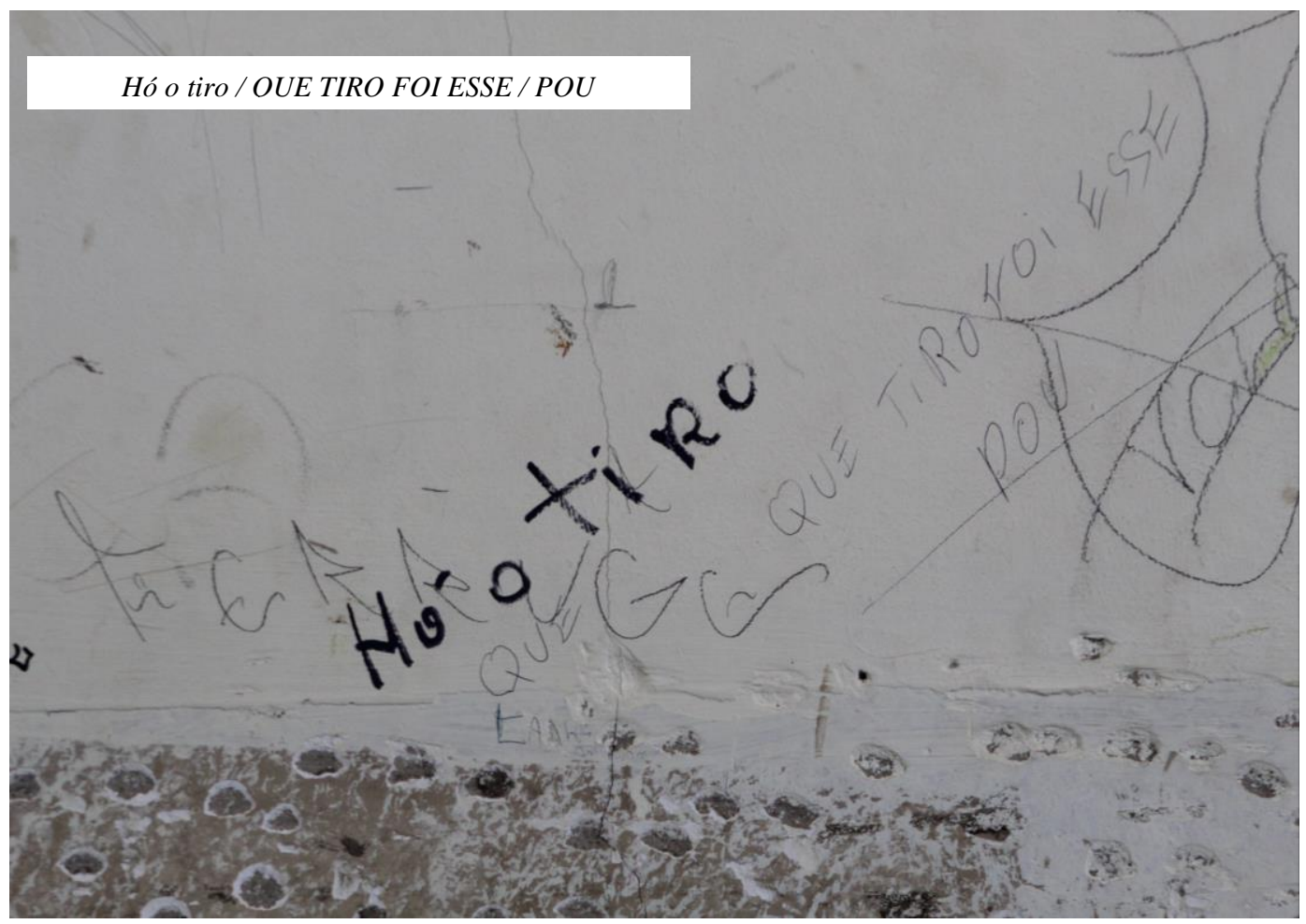

Imagem 34 - Pichação impressa na parede de uma das salas da Escola Nelson Rodrigues

Por conta disso, os sujeitos na escola veem nas pichações um caminho para a comunicação anônima acerca daquilo que a escola nega. Muitas vezes, esse negar da escola está relacionado a seus tabus, racionalidades e construções sociais, processos dos quais consideram inúteis alguns elementos e conceitos da vida cotidiana, como por 
exemplo, os times de futebol, a sexualidade, os entraves sociais comunitários e a repressão sofrida dentro e fora das escolas.

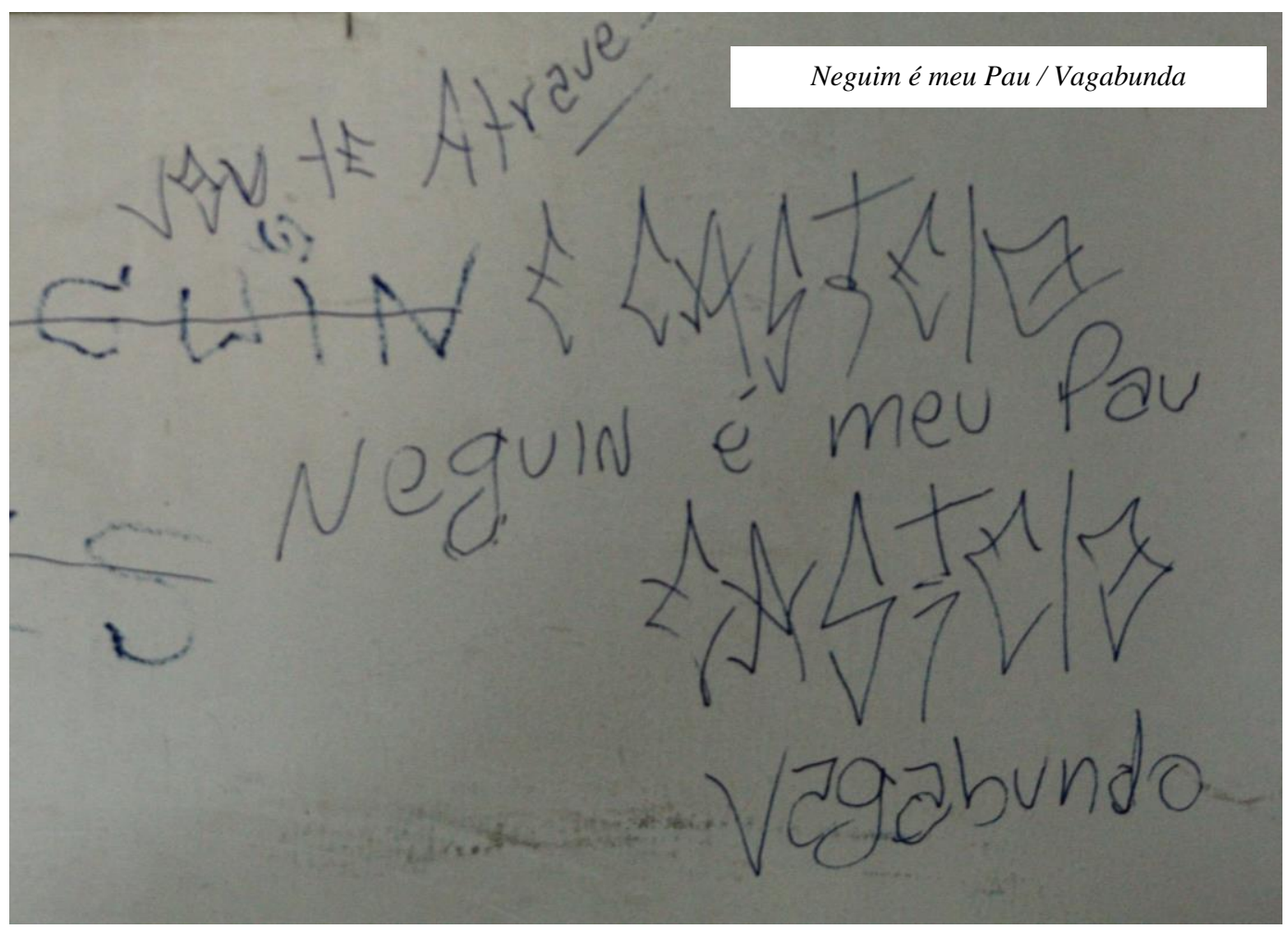

Imagem 35 - Pichação impressa na parede de uma das salas da Escola Nelson Rodrigues

Nos banheiros das escolas investigadas, muitas mensagens manifestadas por meio das pichações revelam o forte apelo à sexualidade e questões de gênero culturalmente construídas. Como ainda é um tabu falar do corpo, dos seus prazeres e de suas múltiplas sexualidades na escola, os banheiros têm sido um dos vários lugares em que os copos escolarizados manifestam os seus desejos, preferências e ofensas. Em muitos casos, esse modo de comunicação faz o uso de desenhos, símbolos e siglas que remetem as genitálias do corpo humano. De modo geral, conforme investigações realizadas por Cunha e Silva (2016), o fenômeno da comunicação escrita presente nos banheiros tem significado específico:

Denota uma forma de heterotopia, ou seja, o que verdadeiramente não tem lugar, espaços absolutamente outros, espaços diferentes para comunicação que não foram reservados para isso, justapondo uma regra em um lugar real, que normalmente, seriam ou deveriam ser incompatíveis para o fenômeno, há vários registros de comunicação nos limites impostos (paredes e portas). Surge uma heterotopia, uma contestação dos espaços onde diariamente 
vivemos, um "não lugar" que desabrocha como um espaço imaginário, onde a "linguagem se entrecruza com o espaço". (CUNHA e SILVA, 2016, p.167).

A narrativa dos autores corrobora para o entendimento de que as pichações podem ser também uma forma de contrariar uma regra presente na escola, na qual os sujeitos não encontram espaços para afirmar seus desejos e anseios.

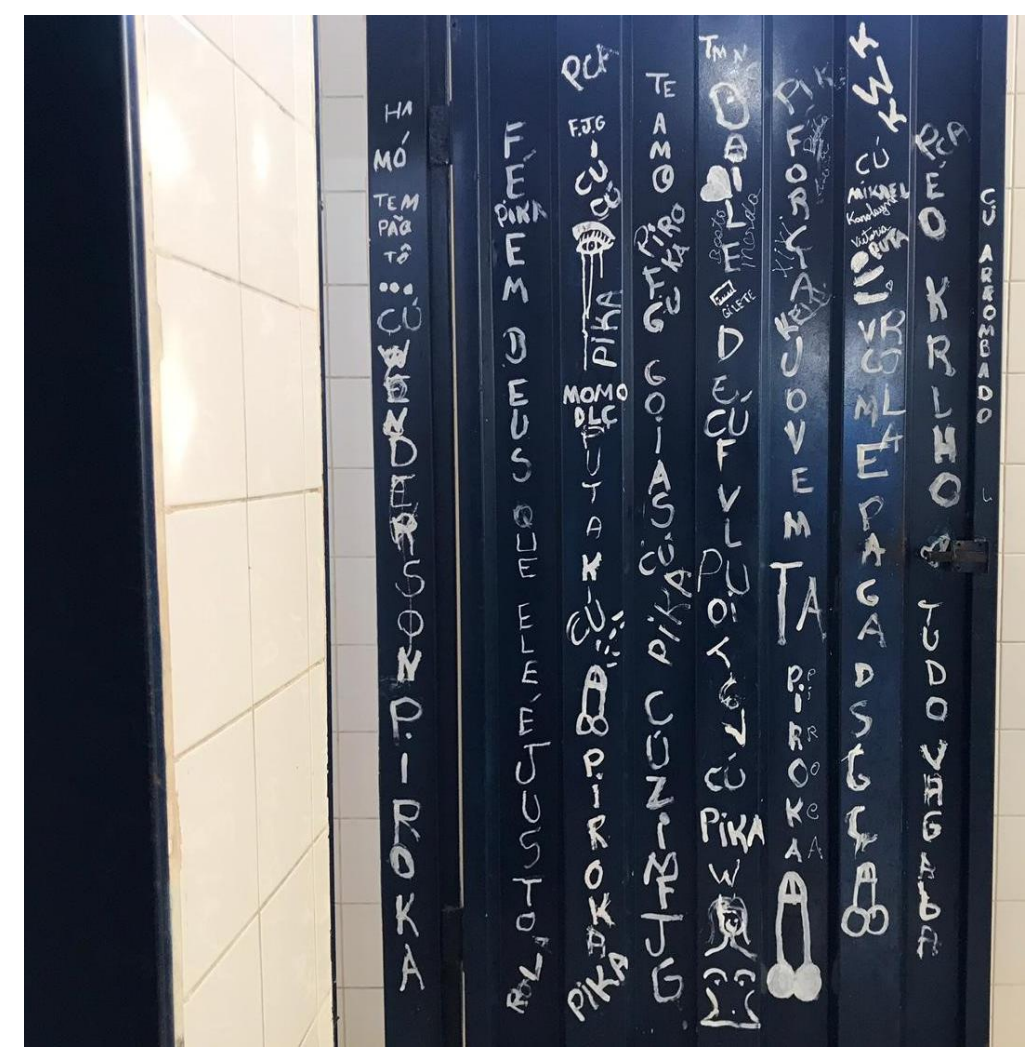
Imagem 36 - Pichação na porta do banheiro da Escola Nelson Rodrigues

Conforme afirmam os autores mencionados, as pichações configuram-se como uma forma de contestar os espaços, suas formas de organização, engessamento, regras e tabus. De acordo com as ideias de Vaz (2013):

\begin{abstract}
Se a pichação é algo que está mais para a transgressão, para o desvio aos padrões, o que seria a pichação dentro do espaço escolar? Basta entrar em uma escola para percebermos o quanto marcas pessoais são deixadas pelos jovens, registrando sua passagem por ela. As marcas, seja por meios intencionais ou pelo desgaste do uso, demonstram o quanto esses espaços são habitados, o quanto há vida pulsante neles (VAZ, 2013, p.90).
\end{abstract}

Como se vê, as pichações representam a vida pulsante dos sujeitos que passam pela escola. É a forma que estes sujeitos encontraram para manter viva as suas memórias. Ainda, as pichações na escola constituem a construção de uma identidade 
dos corpos escolarizados, muitas vezes marcada pelo adestramento, dominação e repressão desses corpos.

De modo geral, pensar com o corpo em meio a um sistema de ensino assinalado por sistemas de controle e punição não é uma tarefa fácil. Primeiro porque isso significa romper com as ideias conservadoras ainda predominantes nos sistemas e nas práticas escolares. Segundo porque muitas unidades escolares, até o momento, não se encontram preparadas para evidenciar o corpo como um componente central nos processos de ensino e aprendizagem escolar. Assumir isso significa partir para o enfrentamento de um sistema tradicional, organizado e voltado para a dominação.

Mesmo diante dos embaraços, é preciso demonstrar a necessidade de tornar o corpo o objeto central da aprendizagem escolar, considerando-o como a morada de um sujeito em formação. Acredito que nesses moldes poderemos falar em uma educação do corpo pensada para a liberdade e autonomia dos sujeitos, de modo a despertar novas sensibilidades, aprendizagem e consciência política por meio das práticas escolares. 


\title{
CAPÍTULO IV - TEATRO NA ESCOLA: UM LUGAR PARA PENSAR A EDUCAÇÃO DO CORPO E DAS SENSIBILIDADES
}

\author{
No teatro - a mais complexa de todas as artes \\ porque a todas inclui e com suas \\ complexidades - os artistas (cidadãos) devem \\ fazer-nos ver o que temos diante do narize \\ não vemos, entender o que é claro e nos \\ aparece obscuro. Disse um camponês do MST: \\ "O Teatro do Oprimido é bom porque nos \\ ensina tudo que já sabíamos".
}

Augusto Boal.

Diante das ideias levantadas nos capítulos anteriores, observamos a presença de diferentes formas de educação do corpo na escola, predominando uma educação marcada por procedimentos de repressão, controle e adestramento corporal. Constatouse também as várias facetas da escola na promoção da educação do corpo, assinalada ainda por diversos sistemas de controle e punição. Como vimos, esses sistemas, por sua vez, visam a manutenção de conceitos tradicionais, padronizados e heteronormativos exigidos por grande parcela da sociedade contemporânea. Desse modo, pode dizer que a escola está à serviço do mundo das técnicas e do grande capital, pincipalmente quando contribui para a formação de corpos passivos, obedientes e produtivos no sentido econômico. No conjunto, as escolas têm operado com essa intencionalidade, de modo a atender as expectativas sociais definidas pela racionalidade técnica.

Nesse cenário, o teatro aparece como uma possibilidade de educação do corpo. Ao considerar o corpo nos procedimentos de ensino, o teatro se configura como uma das poucas áreas do saber escolar interessadas em despertar novas sensibilidades. Conforme discussões realizadas no segundo capítulo deste trabalho, a sensibilidade é um componente importante e necessário para a formação de sujeitos ativos, críticos e transformadores do meio em que vivem. De acordo com Surdi (2018): 


\begin{abstract}
A sensibilidade fornece o sentido do corpo que, por sua vez, possibilita viver e perceber o mundo de várias maneiras. A sensibilidade nos dá a capacidade de inventar e criar; e isso nos credencia como seres diferentes, que percebem o mundo de modo diverso. Ela se liga aos detalhes significativos que, para muitas pessoas, passam despercebidos. Assim, ela se torna um fundamento que nos diferencia como seres únicos e livres, com nossas individualidades e singularidades (SURDI, 2018, p.61).
\end{abstract}

Em conformidade com as ideias de Surdi (2018), a sensibilidade é um campo de descobertas para o corpo na escola. Ao considerá-la nos processos de ensino e aprendizagem escolar, abre-se a oportunidade para o diálogo, debate e enfrentamento dos princípios sociais opressores, racistas, separatistas, homofóbicos e discriminatórios. Em razão disso, este capítulo apresenta uma breve discussão acerca da importância do teatro no contexto escolar, como forma de situar a produção sobre as finalidades do teatro na escola para, em seguida, apresentar as possibilidades de uma prática teatral na escola voltada para o despertar de novas sensibilidades. Nesse sentido, analisaremos brevemente as ideias do teatrólogo Augusto Boal para verificar possibilidades de aguçar novas sensibilidades no teatro escola. É oportuno salientar que o termo sensibilidade é encarado não como componente de um sujeito frágil, reprimido e isolado, mas sim como resistência, força e vontade de lutar pela construção de uma sociedade mais justa.

\title{
4.1 - Teatro na escola: para encenar ou para ensinar?
}

\author{
Por que teatro na escola? \\ Para formar atores? \\ Para encenar? \\ Ou para ensinar?
}

Muitos professores de teatro já se viram diante de perguntas como essas. De certo modo, elas possuem pertinência. Na tentativa de respondê-las neste argumento textual, de início podemos dizer que a finalidade do teatro na escola está na promoção de atividades pedagógicas para a formação do sujeito nos aspectos sociais, emocionais, artísticos e estéticos. Para isso, os elementos teóricos e corporais devem dialogar entre si, uma vez que o teatro se manifesta por meio do pensamento e da ação corporal.

Nessa conjuntura, Moraes (2011) revela o padrão de transmissão do saber assumido por muitas escolas em que a quietude corporal do sujeito em formação é condição primordial para um bom aprendizado. Discordando dessa postura, Moraes 
(2011) argumenta sobre as dinâmicas corporais promovidas pela prática pedagógica de teatro como aquelas capazes de provocar no sujeito a imaginação, a emoção, a interação, a participação e a criatividade. Nota-se na linguagem de Moraes (2011) a natureza da prática corporal como condição para um ensino de teatro ativo e construtor de múltiplos saberes. Esse entendimento anuncia a importância do teatro no contexto escolar para a promoção da formação de sujeito autônomos, reflexivos e críticos sobre a realidade em derredor. Do mesmo modo, contribui para afirmar que o fazer teatral na escola provoca uma interação social indispensável para a formação de conceitos culturais e estéticos.

Ao tratar sobre o teatro escolar para a formação do sujeito, Maia (2010) também afirma a vocação do teatro para a apreensão de conceitos inerentes à convivência humana. Segundo a autora, o teatro na escola promove o autoconhecimento, a formação de valores, a habilidade para trabalhar em grupo e o convívio com as diferenças culturais, sociais, sexuais e idiossincráticas. Com base nessas ideias, observa-se a relevância do teatro para a formação do sujeito em relação a conteúdos artísticos, sociais e emocionais. Nesse contexto, a vivência teórica e corporal promovida pela atividade cênica reforça a formação escolar do sujeito, dando-lhes melhores condições para uma atuação ética, respeitosa, crítica e consciente.

Gagliardi (1998), referencia em seus estudos a particularidade do fazer cênico. Segundo o autor, a formação de plateia se configura como uma das finalidades do teatro na escola. Conforme Gagliardi (1998), o jovem espectador precisa apreender os diferentes códigos expressivos da linguagem teatral para uma melhor operação receptiva. De fato, o teatro é portador de uma linguagem constituída por símbolos. O conhecimento desses símbolos teatrais é importante para a operacionalização cognitiva do sujeito condicionado a atividades cênicas.

Cunha (2009), evidencia a relação entre teatro e educação. De acordo com o autor, a atividade teatral na escola resulta na ampliação do horizonte dos sujeitos, tornando-os mais críticos e abertos ao mundo em que vivem. Nas palavras do autor:

Utilizar o teatro aliado à educação, oportuniza aos educandos um conhecimento diversificado e lúdico, onde o aluno libera as suas potencialidades, expressando seus sentimentos, emoções, aflições e sensações [...]. É uma atividade artística que permite ao aluno expressar-se, explorando todas as formas de comunicação humana. A atividade teatral amplia o horizonte dos alunos, melhora sua autoimagem e colabora para 
torná-los mais críticos e abertos ao mundo em que vivem (CUNHA, 2009, p. 295).

Observa-se na concepção do autor a responsabilidade das atividades teatrais na escola. Segundo Cunha (2009), o teatro escolar tem por finalidade considerar o corpo do sujeito, as suas emoções, aflições, sentimentos e sensações. Ao assumir esse percurso o professor possibilita ao sujeito a criação de um ambiente aberto à aprendizagem significativa e de maior significado social. De modo geral, observa-se na poética de Cunha (2009) a preocupação com a formação estudantil vinculada ao despertar de novas sensibilidades.

Abordando o caráter formativo do teatro na escola, Silveira (2009) denuncia a natureza positivista do conceito de arte presente em muitas escolas do país. Em conformidade com o referido autor, essas escolas reproduzem a ideia de arte apenas como preenchimento de tempo, descontração e divertimento. Essa situação é detectada em algumas práticas de ensino de teatro escolar, nas quais as aulas de teatro são engessadas em sala de aula, sem espaço para a liberdade de expressão do corpo. Como se não bastasse, predominam práticas do ensino baseadas na decoração de textos, personagens e movimentos mecanizados desenhados pelos professores. Em outras palavras, são atividades teatrais que exigem poucos processos cognitivos dos estudantes.

$\mathrm{Na}$ intenção de romper com esse constructo, Silveira (2009) ressalta:

Há necessidade de olharmos para a prática com o teatro na escola como um espaço de pronúncia das palavras, a partir do lugar de onde viemos, do que sabemos e somos. Um momento de aprendizado e construção coletiva de conhecimentos, onde sujeitos se assumem como agentes críticos e históricos, possíveis construtores dos novos "papéis" que precisamos assumir para a transformação desta sociedade (SILVEIRA, 2009, p. 05).

Nessa citação, é possível identificar uma das especialidades do teatro na escola: a formação do sujeito para a transformação da sociedade. Essa conjuntura denota uma prática docente mediadora do conhecimento, de modo a provocar novos sentidos e significados ao que se ensina, mas de modo que este ensino esteja voltado para a realidade vivida pelo sujeito.

Hansted (2013) analisa o teatro escolar por meio do conceito de formação cidadã. Para o autor, a experiência com as atividades teatrais pode transformar os sujeitos em cidadãos dotados de pensamentos críticos e autônomos. Segundo o autor: 
As ligações entre o teatro escolar e a cidadania, indicam que a experiência teatral tem o potencial de desenvolver os sujeitos como cidadãos emancipados, com autonomia de pensamento e ação. [...] É uma colaboração que estimula e precisa das relações igualitárias, da participação engajada e da liberdade de expressão, criação e opinião (HANSTED, 2013, p.245).

As palavras de Hansted (2013) evidenciam o estímulo à alteridade provocado pela prática teatral na escola. Nesse contexto, o teatro escolar cria um ambiente de aprendizagem onde as relações humanas são respeitadas e a participação considerada elemento necessário para a prática da liberdade, expressão e criação.

Ribeiro (2014) descreve o drama como uma experiência estética necessária à formação humana. Na concepção do autor, a utilização do drama é um dos caminhos pelos quais o professor pode se distanciar do preestabelecido e das normativas sociais. Nesse processo, por meio da prática mediadora do professor, os sujeitos em formação podem buscar soluções ficcionais, mas, consequentemente, verdadeiras para determinados entraves sociais.

Soares (2014), preocupado com os caminhos do teatro, retrata os rumos tomados pela escola na educação do corpo. Segundo o autor:

\begin{abstract}
O trabalho com o corpo, com a sua sensibilização, poderia acontecer na escola com maior ênfase. No teatro, as ações são orientadas no sentido de tornar o corpo ágil, expressivo, aberto à captação e resposta a estímulos poéticos. O intuito é deixá-lo flexível, disposto. Na escola, o corpo idealizado parece ser o imóvel, docilizado e condicionado a pequenos espaços, a circulações previstas, à obediência acrítica (SOARES, 2014, p.311).
\end{abstract}

A contribuição de Soares (2014) alimenta a premência da mediação pedagógica no desenvolvimento das ações corporais e incorpora a sensibilidade à prática teatral como um componente fundamental para o rompimento das normativas sociais estabelecidas.

Não diferente, a perspectiva de Maia (2010) também aborda essas ideias. Ao discorrer sobre as atividades cênicas escolares, a autora acentua a importância dessa disciplina no currículo escolar, por considerar que o teatro na escola:

Desenvolve habilidades cuja aplicação se estende para diferentes setores da vida social: a capacidade de trabalhar em grupo, a superação dos limites da timidez, a troca de experiências, a responsabilidade, o comprometimento, o respeito à alteridade, a capacidade de ouvir o outro, a solidariedade, a abertura para interagir e compartilhar, o resgate da autoestima e da autoconfiança; bem como as habilidades relacionadas à leitura, à escrita e à 
capacidade de improvisar e se colocar em público. Entretanto, essas habilidades e capacidades, também não se justificam o teatro como disciplina, por si sós. É importante considerar que todas essas habilidades e capacidades ganham sentido singular no contexto próprio do ensino de teatro na escola, caso contrário incorremos no equívoco de considerar o teatro (ou seus elementos constitutivos) como mera ferramenta para o ensino de outras disciplinas, ou para a educação, de maneira geral (MAIA, 2010, p.82).

Em consonância com Maia (2010), o teatro se mostra necessário para o desenvolvimento do sujeito, pois, seus pressupostos teórico-metodológicos pretendem tornar a escola um espaço de reflexão do corpo e das múltiplas relações humanas. Um espaço onde as relações humanas estabelecidas cotidianamente sejam analisadas, repensadas e ressignificadas. Nessa concepção, é reforçada a ideia de teatro não como uma prática formadora de atores, mas sim como uma ação estimuladora do pensamento crítico e autônomo.

Essa, de maneira geral, é a leitura feita pelos profissionais do teatro preocupados com a promoção da equidade social. São perspectivas que contribuem para afirmar a relevância de atividades teatrais na escola, a qual favorece a discussão de temas sociais e políticos relevantes para o exercício da cidadania. Nesse entendimento, o teatro escolar concebe ao sujeito uma aprendizagem significativa, participativa e transformadora, à medida que permite ao sujeito a tomada de consciência sociopolítica necessária para o exercício da cidadania. Nessa perspectiva, a linguagem teatral apresenta-se como portadora de saberes específicos necessários para a formação discente. Conhecê-la é condição essencial para o desenvolvimento de operações intelectuais importantes para o convívio social.

De modo geral, o teatro escolar demonstra interesses vinculados ao processo de construção cênica, no qual os sujeitos envolvidos desenvolvem processos de convivência, alteridade, múltiplos saberes e pensamentos autônomos. Assim, o teatro na escola tem por finalidade ensinar a pensar com o corpo, a conhecer a si mesmo e a redescobrir a vida humana que pulsa na convivência em sociedade. O modo de o teatro promover essas descobertas e sensibilidades se dá por meio de jogos teatrais e atividades de encenação que tomam o corpo como ponto de partida para todo o trabalho cênico. Logo, o teatro na escola serve para ensinar sobre o corpo no mundo e suas contradições por meio da encenação.

Pensando nisso, diante das numerosas propostas pedagógicas de ensino de teatro escolar e não escolar, adotou-se a proposta de Augusto Boal denominada TO - 
Teatro do Oprimido para uma breve análise, haja visto o seu amplo repertório de produção bibliográfica.

Diante disso, é importante salientar que, apesar de não ter escrito para a educação escolar, a poética de Boal está presente em diversos procedimentos de ensino e aprendizagem na escola, inclusive nos diversos livros didáticos de ensino de Artes encaminhados para as escolas nos últimos anos. Nesses moldes, lançaremos novos olhares para a o Teatro do Oprimido de Augusto Boal como um caminho possível para o trabalho com a educação do corpo na escola e para o despertar de novas sensibilidades. Além de sua história política desenvolvida no teatro nacional e internacional, Augusto Boal foi escolhido por ser um autor com o qual venho trabalhando desde a minha formação acadêmica em Artes Cênicas.

\section{2 - Os caminhos de Augusto Boal}

Augusto Pinto Rodrigues Boal viveu os 78 anos de sua vida dedicados ao teatro. Brasileiro, nasceu na cidade do Rio de Janeiro-RJ no ano de 1931 e faleceu em 2009 na mesma cidade devido a complicações em seu quadro de saúde. Durante sua carreira, Boal atuou como dramaturgo, encenador, diretor teatral, político, escritor e teórico no Brasil e no exterior. Seu acentuado interesse pelo teatro corroborou para o desenvolvimento de várias pesquisas envolvendo o teatro e a transformação social.

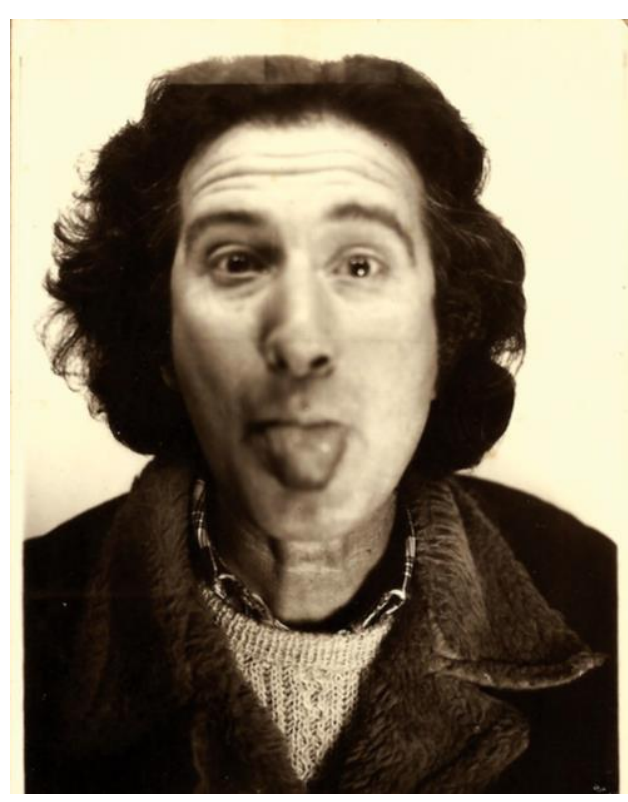

Imagem 37 - Foto de Augusto Boal extraída da capa de um de seus livros intitulado A Estética do Oprimido, publicado pela Editora Garamond, na cidade do Rio de Janeiro em 2009. 
Sua trajetória cênica resultou na formulação de teorias acerca de seu trabalho, sendo conhecida em vários países do mundo com o título TO - Teatro do Oprimido. Para a elaboração de seu método, Boal apropriou-se das ideias de vários autores, dentre eles destacam-se o teatrólogo Bertold Brecht e o pensador Paulo Freire.

Boal acreditava na transformação da sociedade por meio da formação da consciência sociopolítica advinda das práticas teatrais. Especificamente na década de 1960, ele desenvolveu diversos trabalhos preocupados em provocar a formação da consciência social e política com as classes trabalhadoras e camponesas. Teve grande influência no Teatro de Arena de São Paulo e criou na cidade do Rio de Janeiro o CTO - Centro de Teatro do Oprimido.

Em 1964, o Brasil foi alvo de um golpe militar marcado pela censura e repressão. Por conta desse contexto político e do trabalho de teatro político desenvolvido com as classes sociais oprimidas, Augusto Boal foi exilado do Brasil em 1971. Nesse período, o referido autor percorreu diversos países europeus e latinoamericanos, aliando-se a pensadores e educadores inconformados com a censura e repressão advindas do regime militar brasileiro.

O fato de ter sido exilado do Brasil não fez Boal desistir de seus ideais de transformação social por meio da prática teatral. Pelo contrário, o autor continuou a desenvolver os seus trabalhos e pesquisas nos países por onde viveu.

Em síntese, Boal possui uma extensa produção bibliográfica, entre artigos, livros e traduções. Almada (2012) desenvolveu uma pesquisa bibliográfica, na qual realizou um levantamento da produção científica sobre Augusto Boal e diagnosticou a presença de diversos artigos e livros sobre as ideias do autor publicados em diferentes idiomas. Dentre eles, destacam-se as produções nos idiomas português, espanhol, alemão, dinamarquês, finlandês, francês, norueguês, inglês e sueco.

Esse contexto demonstra a relevância científica atribuída a Boal e a suas ideias no exterior. A fim de situar as principais obras de Augusto Boal, o quadro abaixo apresenta uma síntese de suas publicações de maior relevância e repercussão científica para a área do teatro.

Quadro 2 - Principais obras publicadas de Augusto Boal

\begin{tabular}{c|c|c}
\hline TÍTULO & ANO & EDITORA \\
\hline Teatro do Oprimido e outras poéticas políticas & 1975, & Civilização Brasileira \\
& Rio de Janeiro
\end{tabular}




\begin{tabular}{|c|c|c|}
\hline $\begin{array}{l}200 \text { exercícios e jogos para o ator e o não-ator } \\
\text { com vontade de dizer algo através do teatro }\end{array}$ & $\begin{array}{l}1977, \\
\text { Rio de Janeiro }\end{array}$ & Civilização Brasileira \\
\hline Stop: ces't magique & $\begin{array}{l}\text { 1980, } \\
\text { Rio de Janeiro }\end{array}$ & Civilização Brasileira \\
\hline Técnicas latino-americanas de teatro popular & $\begin{array}{c}1984, \\
\text { São Paulo }\end{array}$ & Hucitec \\
\hline Teatro Legislativo & $\begin{array}{c}1996, \\
\text { Rio de Janeiro }\end{array}$ & Civilização Brasileira \\
\hline Jogos para atores e não-atores & $\begin{array}{l}\text { 1998, } \\
\text { Rio de Janeiro }\end{array}$ & Civilização Brasileira \\
\hline Hamlet e o filho do padeiro: memórias imaginadas & $\begin{array}{l}2000, \\
\text { Rio de Janeiro }\end{array}$ & Record \\
\hline $\begin{array}{c}\text { O Arco-Íris do Desejo: método Boal de teatro e } \\
\text { terapia }\end{array}$ & $\begin{array}{l}2002, \\
\text { Rio de Janeiro }\end{array}$ & Civilização Brasileira \\
\hline O teatro como arte marcial & $\begin{array}{l}2003, \\
\text { Rio de Janeiro }\end{array}$ & Garamond \\
\hline A Estética do Oprimido & $\begin{array}{l}2009, \\
\text { Rio de Janeiro }\end{array}$ & Garamond \\
\hline
\end{tabular}

Fonte: Quadro elaborada pelo pesquisador por meio de pesquisas realizadas na internet.

Além da expansiva produção bibliográfica, Augusto Boal recebeu diversos títulos e prêmios significativos no exterior, dos quais podemos mencionar: a) o Officier de I"Ordre des Arts et des Lettres, outorgado pelo Ministério da Cultura e da Comunicação da França em 1981; b) a Medalha Pablo Picasso, conferida pela Unesco em 1994; c) a nomeação como embaixador mundial do teatro pela Unesco no ano de 2009. O reconhecimento mundial de Boal é encontrado também na contracapa de um de seus livros, intitulado $O$ teatro como Arte Marcial, nos quais estão declarados os seguintes comentários: a) "Augusto Boal reinventou o Teatro Político e é uma figura internacional tão importante quanto Brecht ou Stanislawsky." - The Guardian, jornal inglês; b) "Boal é um dos maiores pesquisadores do teatro (...). Outros pensavam que tinham as boas respostas. Boal faz as boas perguntas". Time Out - Londres; c) "Boal conseguiu fazer aquilo com que Brecht apenas sonhou e escreveu: um teatro alegre e instrutivo. Uma forma de terapia social. Mais do que qualquer outro homem de teatro vivo, Boal está tendo um enorme impacto mundial". - Richard Schechner, diretor de The Drama Review; d) "Boal é um dos mais radicais e originais homens do teatro internacional". - New Statesman - Revista semanal inglesa. Ao que tudo indica, o reconhecimento mundial de Boal comprova a veracidade de suas ideias. Todo esse repertório e reconhecido atribuído as ideias de Boal tem contribuído bastante para a produção e pesquisa na área do teatro na atualidade, englobando grupos de TO - Teatro do Oprimido e grupos de pesquisas espalhados pelo mundo. 


\section{3 - Os componentes do Teatro do Oprimido}

O Teatro do Oprimido de Augusto Boal é um método que busca transformar o corpo, as percepções e as sensibilidades, fazendo com que o sujeito assuma uma condição de corpo atuante, vivo, sensível e capaz de confrontar as normativas sociais estabelecidas. Nessa perspectiva, o sujeito participante terá melhores condições para compreender as contradições presentes no meio social em que vive.

De fato, os procedimentos de ensino do Teatro do Oprimido são provocativos e transformam as cenas em ações políticas em favor da luta de classes, do enfrentamento social e da ruptura de modelos que pouco contribuem para a equidade e exercício da cidadania. De modo geral, os procedimentos que compõe o Teatro do Oprimido são apontados por diferentes pesquisadores como um teatro político capaz de promover a liberdade e a autonomia de pensamento e ação. O próprio autor, em uma de suas obras, afirma que:

\footnotetext{
Todo teatro é necessariamente político, porque políticas são todas as atividades do homem, e o teatro é uma delas. Os que pretendem separar o teatro da política, pretendem conduzir-nos ao erro - e esta é uma atitude política. Neste livro pretendo igualmente oferecer algumas provas de que o teatro é uma arma. Uma arma muito eficiente. Por isso, é necessário lutar por ele. Por isso, as classes dominantes permanentemente tentam apropriar-se do teatro e utilizá-lo como instrumento de dominação. Ao fazê-lo, modificam o próprio conceito do que seja o "teatro". Mas o teatro pode igualmente ser uma arma de libertação. Para isso é necessário criar as formas teatrais correspondentes. É necessário transformá-lo (BOAL, 1975, p.13).
}

Nessas circunstâncias, conforme salienta Boal (1975), o Teatro do Oprimido preza pelo diálogo como um caminho para a formação de uma consciência política e social rumo à luta contra as classes dominantes. Por conta disso, o Teatro do Oprimido é consagrado por muitos pesquisadores também como um teatro dialético, principalmente pelo fato de seu método provocar o diálogo com diferentes pares dialéticos, como por exemplo: o dominante e o dominado; o oprimido e o opressor; o burguês e o proletário; dentre outros.

De início, podemos considerar um elemento fundamental nas ideias de Boal, que é a democratização dos meios de produção teatral, na qual os sujeitos menos favorecidos são também considerados como produtores e apreciadores de teatro. De acordo com o autor, o teatro se manifesta em nós nas múltiplas relações que estabelecemos com o cotidiano, pois: 
O Teatro do Oprimido é teatro na acepção mais arcaica da palavra: todos os seres humanos são atores, porque agem, e espectadores, porque observam. Somos todos espect-atores. O Teatro do Oprimido é uma forma de teatro, entre todas as outras. [...] A linguagem teatral é a linguagem humana por excelência, e a mais essencial. Sobre o palco, atores fazem exatamente aquilo que fazemos na vida cotidiana, a toda hora e em todo lugar. Os atores falam, andam, exprimem ideias e revelam paixões, exatamente como todos nós em nossas vidas no corriqueiro dia a dia. A única diferença entre nós e eles consiste em que os atores são conscientes de estar usando essa linguagem, tornando-se, com isso, mais aptos a utilizá-la. Os não atores, ao contrário, ignoram estar fazendo teatro, falando teatro, isto é, usando a linguagem teatral, assim como Monsieur Jourdain, o personagem de $O$ burguês fidalgo de Molière, ignorava estar falando em prosa, quando falava (BOAL, 1998, p. 09).

As considerações de Boal (1998) revelam alguns componentes de seu método. O primeiro deles refere-se ao termo espect-ator. Segundo as proposições de Boal, todos os sujeitos participantes das manifestações teatrais são espectadores e podem assumir o lugar dos atores por meio de procedimentos e regras estabelecidas. $\mathrm{O}$ rompimento da chamada quarta parede no teatro possibilita o diálogo permanente entre os espectadores e a cena. De acordo com o autor, essa abertura possibilita a tomada de uma consciência sociopolítica necessária para a transformação social e exercício da cidadania.

O Teatro do Oprimido é constituído por um conjunto de procedimentos teatrais pensados para o trabalho com questões sociais envolvendo a opressão, a repressão, a exploração e o questionamento do sistema social predominante. Assim, os procedimentos de ensino de Teatro do Oprimido possuem a finalidade de despertar novas sensibilidades, principalmente quando enfatiza a existência de um pensamento sensível e de uma estética própria do oprimido.

O Teatro do Oprimido é constituído por um conjunto de exercícios, jogos e técnicas teatrais, dentre os quais se destacam os Jogos Teatrais, o Teatro-Imagem, o Teatro-Fórum, o Teatro Invisível, o Teatro-Jornal, o Teatro-Fotonovela, o TeatroJulgamento, o Teatro Legislativo, a Quebra de Repressão, o Arco-Íris do Desejo, dentre outras $^{8}$. Segundo Boal, esses procedimentos de ensino de teatro não podem ser trabalhados separadamente, pois, juntos constituem o que ele denomina de Teatro do Oprimido.

\footnotetext{
${ }^{8}$ Em seu livro intitulado Teatro do Oprimido e outras poéticas políticas, publicado pela Editora Civilização Brasileira em sua primeira versão no ano 1975, Augusto Boal descreve detalhadamente todos os seus procedimentos teatrais enumerados no texto acima. Especificamente, as descrições iniciam-se na página 165 e se estende até a página 180. Nesses escritos, Boal demonstra como utilizar cada procedimento de uma forma bastante didática.
} 
Ao explicar sobre o modo pelo qual as classes dominantes se apropriaram do teatro, Boal tece reflexões pertinentes e apresenta uma figura extremamente importante para o desenvolvimento dos seus procedimentos de ensino teatral. Segundo Boal (1975):

\begin{abstract}
No princípio, o teatro era o canto ditirâmbico: o povo livre cantando ao ar livre. O carnaval. A festa. Depois, as classes dominantes se apropriaram do teatro e construíram muros divisórios. Primeiro, dividiram o povo, separando atores de espectadores: gente que faz e gente que observa. Terminou-se a festa! Segundo, entre os atores, separou os protagonistas das massas: começou o doutrinamento coercitivo! O povo oprimido se liberta. E outra vez conquista o teatro. É necessário derrubar muros! Primeiro, o espectador volta a representar, a atuar: teatro invisível, teatro foro, teatro imagem, etc. Segundo, é necessário eliminar a propriedade privada dos personagens pelos atores individuais: Sistema Coringa (BOAL, 1975, p.135).
\end{abstract}

Em concordância com Boal (1975), o Teatro do Oprimido possui um modo próprio de produzir a arte teatral, atribuindo novos sentidos e significados. Conforme mencionado por Boal (1975), um outro componente fundamental do Teatro do Oprimido é o sistema Coringa. Este sistema consiste em permitir aos atores a possibilidade de assumirem uma mesma personagem em uma peça. Desse modo, Boal acreditava que o distanciamento do ator em relação a personagem não permitiria ao ator identificar-se com uma personagem específica.

Pensando sobre isso, para o contexto escolar, é possível identificar o quanto esse sistema possibilita explorar diferentes conceitos, como por exemplo a caracterização de uma personagem, o uso de símbolos ou adereços que caracterizem uma personagem, bem como a possibilidade de um mesmo ator representar várias personagens em uma mesma montagem cênica, dentre outras questões. Todo esse repertório pode anunciar novas possibilidades de pensar o fazer teatral na escola, de modo a provocar rupturas dos costumes tradicionais de se fazer teatro.

\title{
4.4 - O Teatro do Oprimido como possibilidade de educação do corpo na
}

escola

O teatro na escola é uma das mais belas formas de manifestação artística que pode fornecer ao corpo escolarizado as possibilidades para o despertar de novas sensibilidades. A estética presente no Teatro do Oprimido, por exemplo, configura-se 
como um modo particular de pensar a sensibilidade. Boal se diferencia das demais propostas de teatro pelo teatro político ao qual seus métodos promovem. Em outras palavras, trata-se de uma estética voltada para a sensibilidade dos sujeitos oprimidos, de forma a formar força política para a luta e enfrentamento. Trata-se de uma sensibilidade que oferece ao corpo condições para lutar contra as mais variadas formas de desigualdades e opressão. De modo geral, o Teatro do Oprimido desenvolvido por Augusto Boal pode provocar diferentes experiências estéticas com os sujeitos participantes. Assim, é preciso dizer que as experiências estéticas suscitadas pelo Teatro do Oprimido não podem ser confundidas com as experiências práticas cotidianas. De acordo com Surdi (2018):

A experiência estética difere da experiência prática no seguinte sentido: enquanto a experiência prática está relacionada com o pragmatismo ou utilitarismo, a experiência estética procura perceber o ser do objeto; fazer com que ele apareça por si só e traga consigo sua verdade (SURDI, 2018, p.35).

Como se vê, a experiência estética não é caracterizada por um utilitarismo pragmático, tão pouco carregada de uma única estética, como se a verdade e os valores humanos fossem princípios universais. De acordo com Boal (2009):

\footnotetext{
A estética não é a ciência do Belo, como se costuma dizer, mas sim a ciência da comunicação sensorial e da sensibilidade. É a organização sensível do caos em que vivemos, solitários e gregários, tentando construir uma sociedade menos antropofágica. [...] O Belo está na coisa e no olhar. Nem todos olhares veem a mesma coisa. $\mathrm{O}$ dono do olhar é um cidadão que vive em sociedade de classes, castas, casas grandes ou senzalas. Não existe o olhar puro - é impossível nos desfazermos da carga social (cultural) entranhada em nosso corpo e em nossa mente - esta carga é possante filtro através do qual vemos o mundo. [...] "O feio é belo!" - não há nisto nenhuma contradição, pois bela é a verdade escondida que a arte revela! O Belo é o reluzir da verdade através dos meios sensoriais - dizem alguns filósofos, e eu concordo. [...] Nós, com a Estética do Oprimido, buscamos a nossa verdade: uma Arte Pedagógica inserida na realidade política e social, e dela parte! (BOAL, 2009, p.31).
}

Conforme destaca Boal (2009), o Teatro do Oprimido trabalha com a Estética do Oprimido, descrito em seu livro A estética do Oprimido. De acordo com Boal, o Teatro do Oprimido assume uma totalidade denominada de Estética do Oprimido. Nesse processo, os sujeitos envolvidos organizam suas sensibilidades em relação à desordem pensada pelo sistema social dominante. Assim, seu método pretende revelar aos sujeitos oprimidos a realidade encoberta pelo mundo das técnicas e do capital. De modo geral, 
trabalhar com os procedimentos de Teatro do Oprimido na escola pode contribuir para o despertar de novos olhares e vislumbrar as várias verdades presentes em um mesmo objeto de estudo. Ainda de acordo com o autor, a Estética é uma relação sujeito-objeto, fruto de uma dialética contínua. Nesses moldes, os espaços de educação do corpo vão além daqueles relacionadas ao corpo passivo, imóvel e reprimido.

As reflexões de Boal (2009) reforçam também a necessidade de pensarmos a arte teatral que pretendemos para escola e, junto com ela, as experiências estéticas, as verdades sobre o mundo, os corpos, seus tabus e suas sensibilidades. Desse modo, a arte teatral na escola não é uma atividade meramente transmissora, engessada, repetitiva ou para divertir as crianças em seus tempos ociosos.

Pelo contrário, se os ideais docentes estiverem orientados por uma concepção de equidade, certamente o teatro escolar será um caminho para a produção de saberes relevantes para o convívio social, pois, conforme salienta Boal (2009, p.35), devemos tomar partido e nos juntarmos a um dos lados dos conflitos que enfrentamos todos os dias e, se formos éticos, nosso partido será sempre o dos oprimidos. De acordo com Maia (2010):

\begin{abstract}
A linguagem teatral, utilizada para explicar as relações sociais e seus consequentes problemas, é um espaço alternativo e democrático para o confronto de ideias originadas de diferentes realidades culturais. O teatro, como ferramenta de ensino-aprendizagem, consegue a valorização do caráter singular e especial do acontecimento trivial, dos fatos históricos, das ações individuais e coletivas. A educação, de forma geral, deve trabalhar e envolver fatores emocionais e intelectuais integralmente, de maneira que contribua para a mobilização social em torno de temas de interesse geral, que propiciem, sobretudo, a politização do espaço público e privado, por meio da crítica social e da consciência histórica (MAIA, 2010, p.80).
\end{abstract}

A plenitude das ideias de Maia (2010) fornece subsídios para refletir sobre a importância do Teatro do Oprimido no contexto escolar e as diversas possibilidades de aprendizagem que esse método pode provocar. Por fim, é preciso encarar a prática do teatro na escola como um caminho para a transformação social pois, como bem salientou Boal (2009, p.54), é necessário mostrar a forma pela qual os opressores usam os canais estéticos para intensificar a opressão e praticar os diversos atos camuflados de docilidade e obediência dos corpos. Com isso, o Teatro do Oprimido deve ser visto como uma forma de educação do corpo para o despertar de novas sensibilidades. 
Dessa maneira, esperamos que as diversas experiências estéticas manifestadas pelo Teatro do Oprimido na escola sejam os ingredientes necessários para provocar e estabelecer mudanças sociais. Contudo, conforme Surdi, devemos ter claro que:

\begin{abstract}
O que ocorre, normalmente, é que nossa experiência prática tem muita pressa em colocar cada coisa em seu devido lugar para ser utilizada em nossas relações com o mundo e com as coisas que nos cercam. Com isso, priva-nos do sabor do sentimento e das sensações que precisam de tempo e espaços diferentes para contemplar a beleza da natureza. A experiência estética se fixa apenas no sentimento de prazer proporcionado pela percepção do objeto. A beleza não está no objeto observado e nem em quem o observa. Está na relação entre ambos. Mais precisamente, quando essa relação desaparece e se torna uma só (SURDI, 2018, p.36).
\end{abstract}

Em concordância com as palavras de Surdi (2018), essa deve ser a essência do teatro na escola, uma prática corporal provocadora de experiências estéticas e transformadora do modo pelo qual os sujeitos se veem no mundo, encorajando-os a provocar mudanças sociais necessárias para o exercício da cidadania e, consequentemente, para a vida em sociedade.

A fim de demonstração, apresento abaixo uma peça de Teatro-Fórum escrita em parceria com alguns estudantes do Ensino Médio da escola onde desenvolvo minhas atividades docentes. Nela, trabalhamos a opressão vivenciada pelas pessoas obesas e suas frustrações quanto aos padrões estipulados pela mídia. É oportuno ressaltar que esses estudantes fazem parte do Grupo de Teatro Repertório em Movimento, criado em 2016 quando iniciei minhas práticas pedagógicas de teatro na escola.

\title{
É POSSÍVEL SER FELIZ GORDA?!
}

Personagens

MIRELLA

GABY

MARCOS

VENDEDORA

GERENTE DA LOJA 


\section{PRÓLOGO}

Gaby e Mirella se conheceram na escola e cultivam uma amizade de mais de dez anos. As jovens aparentam dezenove anos de idade. Apesar de frequentarem a academia todos os dias e possuírem uma dieta equilibrada, elas pesam pouco mais de cem quilos. Gaby e Mirella já foram vítimas de várias situações de opressão por conta de seus corpos estarem fora dos padrões estipulados pela mídia.

\section{CORO}

Entram as personagens batendo palmas sincronizadas, se posicionam em cena $e$ declamam trechos traduzidos da música "Crazy" da banda norte americana Simple Plan.

Me diga o que há de errado com a sociedade

Quando em todos os lugares que eu olho

Eu vejo garotas morrendo

Para ser como as que aparecem na TV

Elas não pararão até

Terem alcançado seus sonhos

Pílulas para emagrecer, cirurgias

Fotos editadas para as revistas

Dizendo a elas como elas devem ser

Isso não faz sentido para mim

Todos estão ficando loucos?

Alguém pode me salvar?

Alguém pode me dizer o que está acontecendo?

Se você abrir seus olhos

Você verá que alguma coisa está errada

\section{PRIMEIRA CENA - O CONVITE}

\section{MARCOS}

Alô! Gaby?!

\section{GABY}

Oi! Quem é?

\section{MARCOS}

Sou eu o Marcos. Gaby, estou te ligando para convidar você e a sua amiga Mirella para a minha festa de aniversário. Será no próximo sábado aqui em casa.

\section{GABY}

(Admirada) Nossaaaa primo, que legal! A Mirella vai amar. Vocês já estão namorando? 


\section{MARCOS}

(Surpreso) Nãooooo Gaby, ainda não. Eu pensei que seria bacana eu pedir ela em namoro aqui na festa. Assim, aproveito e apresento ela para os meus pais e minha irmã caçula.

\section{GABY}

(Empolgada) Suuuuper da hora primo. Vou convidar ela.

\section{MARCOS}

Fechou então. Mas se liga numa coisa: a festa é temática. Minha mãe pensou no Bob Esponja.

\section{GABY}

(Espantada) Eitaaaaa Marquinhos, tudo bem então. Vou aproveitar e chamar ela para irmos ao shopping comprar uma blusa do Bob Esponja. Assim aproveito e "jogo o barulho" nela para você.

\section{MARCOS}

De boa prima. Vou nessa, ainda tenho que convidar a Patrícia, o Afonso e a Estela. Dê um beijo na tia Lia por mim. Tchau!

\section{GABY}

Beleza primo. Tchau! Beijos e até sábado!

\section{SEGUNDA CENA - INDO ÀS COMPRAS}

\section{GABY}

Amiga do céu! Estou com muito medo de não encontrar uma camisa do Bob Esponja com o meu tamanho. Tenho medo de ficar descaracterizada na festa!

\section{MIRELLA}

Calma Gaby, nós vamos encontrar. Lá no Siriguela Shopping tem muitas lojas. Se não acharmos na C\&BÁ, na Risadochinelo é certeza que tem.

\section{GABY}

(Ironica) Você já tem sua camisa né Mirella, por isso está aí toda alegrinha. Afinal, onde foi que você comprou a sua? 


\section{MIRELLA}

Olha, eu comprei em São Paulo quando fui com minha mãe no mês passado. Mas olha, não foi nada fácil achar roupas com as minhas medidas.

\section{GABY}

Pois é, imagina para mim que sou mais grandinha que você. (Em tons de desânimo) Haaaa amiga, é muito difícil ser gorda nesse mundo. Sempre estamos fora dos padrões, somos as erradas, não cuidados de nós e blá blá blá. Isso precisa mudar!

\section{MIRELLA}

(Confiante) Haaaa Gaby, eu já me acostumei e nem me importo.

\section{GABY}

(Espantada) Sérioooo? Não se importa quando te olham com indiferença?!

\section{MIRELLA}

(Convencida) Não, nem um pouco. E você já reparou que o tamanho "G" das roupas tem diminuído?

\section{GABY}

Como assim diminuído?

\section{MIRELLA}

(Um pouco histérica) Gaby, Gaby! Compra uma blusa tamanho "G" na feira hippie para você ver. Não passa nem no pescoço.

\section{GABY}

Haaaa, vai ver são para gordinhas magras, coisas que nós não somos. Apesar de tudo, eu me incomodo sim com as pessoas e seus olhares de preconceito... (sonhando acordada) é como se gordo fosse sinal de descuido.

\section{MIRELLA}

(Toda radiante, acorda Gaby) Amiga você precisa aprender comigo a ignorar as pessoas e o que elas dizem. Só assim você terá paz e será feliz.

\section{GABY}


(Um pouco irritada) Haaa isso não é pra mim, você me conhece. (Animada) Olhaaaaa, Bob Esponja na vitrineeeeeee! Vamos lá Mirellaaaa, vamos ver se tem o meu tamanho! (As amigas entram na loja)

\section{TERCEIRA CENA - NA LOJA}

\section{VENDEDORA}

Boa tarde! Vocês já possuem nossos cartões C\&BÁ?!

\section{MIRELLA}

(Um pouco sarcástica) Já sim!

\section{VENDEDORA}

(Muito curiosa) Tudo bem então! Posso ajudar vocês em alguma coisa? Estão procurando peças para presente?

\section{GABY}

(Um pouco estressada) Não, não! É para mim mesmo!

\section{VENDEDORA}

(Com cara de espanto) Vish! Acho que não temos o seu tamanho moça. Nossa loja só trabalha com tamanhos padronizados.

\section{GABY}

(Brava) Como assim? Por acaso estou fora do padrão? Que padrão é esse de vocês? Eu uso tamanho "G" e essas peças aqui são todas tamanho "G”. (Procurando o provador) Onde é o provador?

\section{VENDEDORA}

(Em tons de deboche) Moça, não vai adiantar! As peças dessa loja são para pessoas que estão em forma e que cuidam da saúde.

\section{GABY}

(Chateada) Está achando que eu não sou uma pessoa saudável é?

\section{GERENTE}

Algum problema por aqui? 


\section{MIRELLA}

(Preocupada) Gaby vamos embora! Vamos comprar em outra loja.

\section{GABY}

(Muito irritada) Não Mirella! Primeiro vou resolver esse problema. (Direcionando-se para a gerente) Olha, há sim, há um grande problema nessa loja: essa vendedora é o problema. Como pode uma vendedora abordar a cliente dessa forma, já dizendo que eu não me encaixo nos padrões das roupas da loja?! Isso é um absurdo!

\section{GERENTE}

(Serena) Bem, acho que você não entendeu. Vou tentar explicar melhor. A nossa loja tem uma política voltada para o público feliz. Veja! Estão em todas as fotografias afixadas nas paredes da loja (apontando para as fotos de pessoas magras afixadas nas paredes da loja). E todas nós sabemos que um corpo feliz é aquele que se encaixa nos padrões. Além disso, todas as pessoas podem se encaixar nos padrões, basta foco e força de vontade.

Início do fórum - Nesse momento, o mediador congela a cena e abre o fórum de discussão, convidando os espectadores para intervirem na cena, com vistas a buscar soluções para o problema de opressão apresentado.

Observa-se no texto dramático acima algumas características peculiares da proposta de Teatro-Fórum de Augusto Boal, marcada pela

\footnotetext{
[...] quebra dos limites entre palco e plateia, entre atores e o público, por meio da possibilidade dos espectadores entrarem em cena no lugar dos personagens que eles julgam oprimidos. A estrutura de uma peça de Teatro Fórum constitui-se na configuração clara de uma situação de opressão. A apresentação serve para iniciar o debate com a plateia sobre a situação de opressão apresentada. Os próprios espectadores, dando sua opinião sobre a situação, entram em cena para interpretarem o personagem oprimido e agem sugerindo estratégias para a solução dos problemas de opressão enfrentados (MST, 2005, p.20).
}

Por esse ângulo, o texto de Teatro-Fórum acima caracteriza-se como uma proposta de trabalho pedagógico para o espaço escolar que pode provocar novos olhares para a questão da obesidade.

É válido lembrar que o objetivo maior da atividade não está na performance cênica, mas sim em incitar, nesse caso, uma discussão rumo à ampliação do olhar que os estudantes possuem acerca dos padrões de beleza e estética estabelecidos em nossa sociedade. É um procedimento de ensino no qual o corpo estará em produção ativa. Em 
outras palavras, o modo de pensar dos sujeitos envolvidos será produzido por meio das palavras e da ação de seus corpos na cena, pois, "só com a Estética, que é a razão do Pensamento Sensível, torna-se possível a mais profunda compreensão do mundo e da sociedade, e de nós mesmos" (BOAL, 2009, p. 119). De modo geral, essa é a Estética do Oprimido conforme descreve Boal em suas obras.

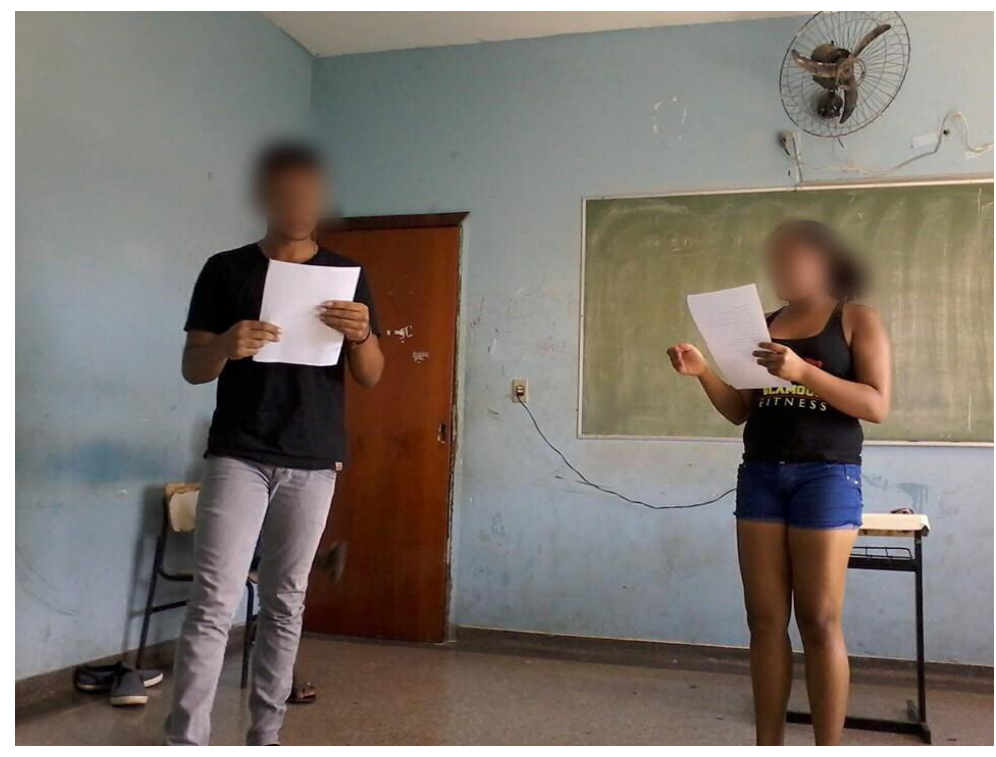

Imagem 38 - Montagem do texto dramático e ensaio da proposta na Escola Nelson Rodrigues

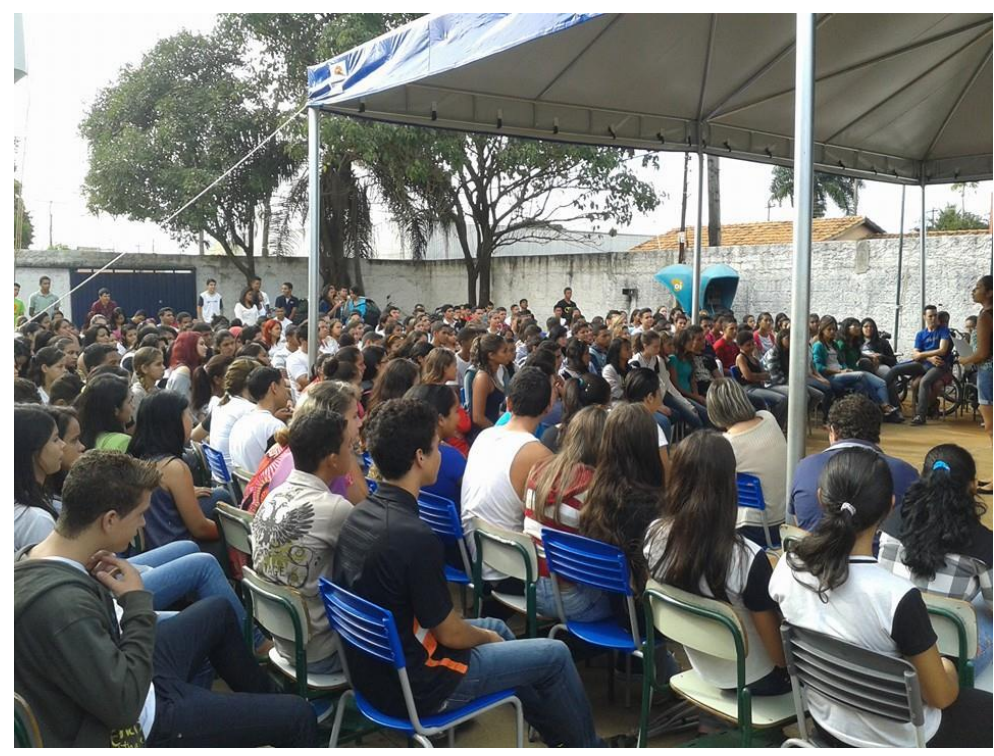

Imagem 39 - Organização do pátio da Escola Nelson Rodrigues para o fórum

Em síntese, os resultados pedagógicos do trabalho realizado com esses alunos foram bastante significativos. Além dos estímulos de empoderamento social com os envolvidos, as atividades de Teatro-Fórum desenvolvidos na escola possibilitaram de 
certo modo a formação de uma sensibilidade sociopolítica necessária para o exercício da cidadania. 


\section{CONSIDERAÇÕES FINAIS}

Arte é direito e obrigação, forma de conhecimento e gozo. Arte é dever de cidadania! Arma de libertação!

Augusto Boal.

Diante das discussões e resultados apresentados ao longo desta pesquisa, podemos afirmar que, apesar dos avanços tecnológicos, científicos e pedagógicos, muitas escolas ainda assumem atitudes de vigilância e punição dos corpos, considerando satisfatória a presença de sistemas de controle e punição das práticas corporais. É importante ressaltar também que essa postura assumida pela escola é fruto do conservadorismo cultural presente nos ideias do povo brasileiro e empregados pelo sistema social dominante.

Por meio desta pesquisa, fica evidenciado o modo controlador, regulador, adestrador e disciplinador de educação do corpo praticado pelas escolas. Mas é preciso dizer que ainda não aprendemos a desenvolver na escola atividades pedagógicas onde o corpo, em sua constituição física, motora, afetiva, cognitiva, social e cultural, seja considerado como o centro de todo o processo. Em outras palavras, dificilmente consideramos o corpo na escola como um produtor de culturas, sensibilidades, saberes e fazeres.

A semelhança dos espaços escolares com os espaços não-escolares, como vimos, revela a ausência de uma identidade necessária aos espaços escolares. Os corpos dos sujeitos negam o espaço escolar porque não encontram nele uma razão de ser. Parece que em nome da racionalidade, muitas escolas deixam de considerar os desejos, as angústias, os sentimentos e as emoções dos alunos. Todo esse percurso corrobora para a não aceitação do espaço escolar, o que por sua vez, gera frustrações e indisposições. Nesse contexto, é preciso refletir sobre o corpo que a escola recebe todos 
os dias, bem como as atividades desenvolvidas, os movimentos estimulados e a ausência de novas sensibilidades.

Outro ponto importante refere-se às experiências estéticas pouco motivadas pelas escolas e que são fundamentais para o despertar de novas sensibilidades. Falamos aqui da sensibilidade como um componente capaz de provocar novas formas de ver o mundo, de compreender o outro e a si mesmo, de enfrentamento, de luta e de resistência. Uma sensibilidade capaz de mover as pessoas para o embate e transformação social. Portanto, se considerarmos a educação como uma prática construtiva, devemos lançar novos olhares para a escola, sua estrutura e suas práticas. Nesse contexto, o teatro, apesar de ser oferecido em poucas escolas, emerge como uma possibilidade de educação do corpo para a transformação social, conforme demonstrado pelas ideias de Augusto Boal em seu método de Teatro do Oprimido. Assim, entende-se que o teatro é cada vez mais necessário nos espaços escolares como forma de provocar novos olhares e rupturas aos padrões normativos. 


\section{REFERÊNCIAS}

ALMADA, Izaías. Boal: embaixador do teatro brasileiro. Monografia de conclusão de curso em Teatro. PROAC, n.28, 2012. Acesso em março de 2019. Disponível em https://institutoaugustoboal.files.wordpress.com/2012/11/almada_monografia_boal.pdf

AMADO, Paula Barreto Dória. Corpo regulamentado, corpo rebelado: Atheneu Sergipense (1909-1911). 116f. 2017. Dissertação (Mestrado). Universidade Tiradentes.

ANGELO, Marina Balastreire. As práticas corporais no trabalho do professor de arte: um estudo em Várzea Paulista/SP. 65f. 2013. Dissertação (Mestrado). Universidade Estadual de Campinas.

ARAUJO, Márcia Feijó de. Linguagem corporal, docência e teoria crítica. 116f. 2014. Dissertação (Mestrado). Universidade Federal do Rio de Janeiro.

ARANTES, Gabriela Villela. A educação física em cena: olhares sobre o Colégio Estadual de Minas Gerais (1956-1973). 170f. 2013. Dissertação (Mestrado). Universidade Federal de Minas Gerais.

BACCIN, Adriana Nolibos. Corpo e cultura de movimento no teatro da formação cultural: ainda Ulisses? 101f. 2013. Dissertação (Mestrado). Universidade Federal de Santa Maria.

BALL, S. J.; MAGUIRE, M.; BRAUN, A. Como as escolas fazem as políticas: atuação em escolas secundárias. Ponta Grossa: UEPG, 2016, p. 11-65.

BARBOSA, Pietrine Paiva. Professores de educação física formados em instituições privadas e a problematização do corpo. 176f. 2017. Dissertação (Mestrado). Universidade Federal de Minas Gerais.

BARCHI, Rodrigo. Pichar, pixar, grafitar, colar: os discursos e representações sobre as pichações nas escolas analisados na perspectiva ambiental e libertária. TEIAS: Rio de Janeiro, ano 8, n 15-16, jan/dez 2007.

BATISTA, Alison Pereira. Conhecimentos sobre o corpo: uma possibilidade de intervenção pedagógica nas aulas de educação física no Ensino Médio. 260f. 2013. Dissertação (Mestrado). Universidade Federal do Rio Grande do Norte.

BOAL, Augusto. Teatro do Oprimido e outras poéticas políticas. Rio de Janeiro: Civilização Brasileira, 1975. 
200 exercícios e jogos para o ator e o não-ator com vontade de dizer algo através do teatro. Rio de Janeiro: Civilização Brasileira, 1977.

. Stop: ces't magique. Rio de Janeiro: Civilização Brasileira, 1980.

. Técnicas latino-americanas de teatro popular. São Paulo: Hucitec, 1984.

. Teatro Legislativo. Rio de Janeiro: Civilização Brasileira: 1996.

Jogos para atores e não-atores. Rio de Janeiro: Civilização Brasileira, 1998.

2000.

Hamlet e o filho do padeiro: memórias imaginadas. Rio de Janeiro: Record,

- O Arco-Íris do Desejo: método Boal de teatro e terapia. Rio de Janeiro: Civilização Brasileira, 2002.

O teatro como arte marcial. Rio de Janeiro: Garamond, 2003.

. A Estética do Oprimido. Rio de Janeiro: Garamond, 2009.

BORGES, Greicibely Faccin; VICENTINI, Max Rogério. Descartes $e$ a psicossomática: a relação mente e corpo no modelo médio. Marília: Fajopa, 2013.

BOURDIEU, Pierre. O poder simbólico. 4. Ed. Trad. Fernando Tomaz. Rio de Janeiro: Bertrand Brasil, 2001.

Sur la télévision. Paris: Liber, 1996.

BRASIL, Lei de Diretrizes e Bases da Educação Nacional. Lei $n^{o}$ 9.394/96, de 20 de dezembro de 1996. Brasília: Senado Federal, Coordenação de Edições Técnicas, 2017.

BRASILEIRO, T. S. A. Autobiografia e formação docente em Rondônia: a busca de uma identidade profissional. In: $31^{a}$ Reunião Anual da ANPEd, 2008, Caxambu. Constituição Brasileira, Direitos Humanos e Educação, 2008.

CABRAL, D. Cultura e identidade: em que medida a escola pode ser um agente de transformação social. Dissertação de Mestrado. Unesp: Araraquara, 2017.

CARVALHO, M. A construção das identidades no espaço escolar. Revista Reflexão e Ação, Santa Cruz do Sul, v.20, n1, p.209-227, jan./jun.2012.

CHAVES, Silvane Lopes. Sobre corpos insolentes: corpo trans, um ensaio estético da diferença sexual na educação. 110f. 2015. Dissertação (Mestrado). Universidade Federal do Pará.

COFFANI, Márcia Cristina Rodrigues da Silva. O corpo no cotidiano da educação física do ensino médio: um estudo sobre suas práticas pedagógico-curriculares. $600 \mathrm{f}$. 2016. Tese (Doutorado). Universidade Federal do Mato Grosso. 
CUNHA, A. H. Teatro na escola: proposta para a educação moderna. Acesso em: $16 / 04 / 2017$.

CUNHA, C. R.; SILVA, A. V. F. O que te alucina? Banheiros, pichações e processos de subjetivação em gênero. Revista Periódicus. Vol.01, nº6, nov.2016-abr.2017, p.166178.

DEMETRIO, Rubia Vanessa Vicente. A dimensão corporal na relação educativa com bebês: na perspectiva das professoras. 170f. 2016. Dissertação (Mestrado). Universidade Federal de Santa Catarina.

DINIZ, Luciene Teixeira. A construção do sujeito encarnado na experiência docente. 62f. 2014. Dissertação (Mestrado). Universidade Cidade de São Paulo.

DUARTE JUNIOR, J. F. O sentido dos sentidos: a educação (do) sensível. 234f. 2000. Tese (Doutorado). Universidade Estadual de Campinas, Campinas, 2000.

DURKHEIM, E. "O que é fato social?" In: As Regras do Método Sociológico. Trad. por Maria Isaura Pereira de Queiroz. 6.a ed. São Paulo, Companhia Editora Nacional, 1972.

FARAH, M. H. S. O corpo na escola: mapeamentos necessários. Revista Paidéia. São Paulo, v.20, n.47, p.401-410, set./dez. 2010.

FERREIRA, Aurélio Buarque de Holanda. Minidicionário da língua portuguesa. Rio de Janeiro: Nova Fronteira, 2000.

FEREIRA, Luiz Olavo Fonseca. $O$ corpo em cena na educação de jovens e adultos: a mobilização para a aprendizagem na EJA por meio dos significados expressos pela corporeidade de mulheres adultas. 187f. 2013. Tese (Doutorado). Universidade Federal de Minas Gerais.

FERRAZ, Wagner. Corpo a dançar: entre educação e criação de corpos. 190f. 2014. Dissertação (Mestrado). Universidade Federal do Rio Grande do Sul.

FILHO, Flavio de Andrade Benini. Educação do corpo na perspectiva de gênero: uma análise de projetos públicos de esporte e lazer. 127f. 2017. Dissertação (Mestrado). Universidade Estadual de Campinas.

FISCGER, Deivis Alexandre. Educação e sensibilidade: tensões e desafios. 89f. 2015. Dissertação (Mestrado). Pontifícia Universidade Católica do Rio Grande do Sul.

FOUCAULT, Michel. Vigiar e Punir: nascimento da prisão. Trad. Lígia M. Ponde Vassalo. Petrópolis: Vozes, 1987.

GAGLIARDI, Mafra. O teatro, a escola e o jovem espectador. In: Comunicação \& Educação, São Paulo, v. 1, n. 31, p. 67 a 72, set./dez. 1998.

GARCEZ, R. C. C. Para uma pedagogia da pichação. 176f. 2000. Dissertação (Mestrado). Universidade Federal de Pernambuco, Recife, 2000. 
GAYA, A. A reinvenção dos corpos: por uma Pedagogia da Complexidade. Revista Sociologias. Porto Alegre, ano 8, n.15, p.250-272, jan./jun. 2006.

HANSTED, Talitha Cardoso. Teatro, educação e cidadania: estudo em uma escola do Ensino Básico. Dissertação de mestrado. UNICAMP: Campinas-SP, 2013.

JUNIOR, Aurélio Bona. O corpo na educação emancipatória da sexualidade: uma análise das iniciativas do governo do Paraná (2008-2009). 160f. 2013. Tese (Doutorado). Universidade Estadual de Campinas.

JUNIOR, Moaldecir Freire Domingos. Por uma educação dos sentidos: um diálogo entre Merleau-Ponty e Ueshiba. 174f. 2013. Dissertação (Mestrado). Universidade Federal do Rio Grande do Norte.

KOCHE, José Carlos. Fundamentos de metodologia científica: Teoria da ciência e iniciação à pesquisa. 20. ed. atualizada. Petrópolis, RJ: Vozes, 1997.

KOLYNIAK FILHO, Carol. Contribuições para o ensino em motricidade humana. In: Discorpo, Revista do Departamento de Educação Física e Esportes da Pontifícia Universidade Católica de São Paulo: São Paulo, 2002, n¹3, p. 27-39.

LE BRETON, David. A sociologia do corpo. $6^{\text {a }}$ ed. Rio de Janeiro: Vozes, 2012.

LIMA, M. A. D. S.; ALMEIDA, M. C. P.; LIMA, C. C. A utilização da observação participante e da entrevista semiestruturada na pesquisa em enfermagem. Revista Gaúcha de Enfermagem. Porto Alegre, v.20, n. esp., p.130-143, 1999.

MAIA, Urânia. Teatro e formação do sujeito. In: BRASIL, Ministério da Educação. Coordenação de Aperfeiçoamento de Pessoal de Nível Superior. Universidade Federal de Goiás. Licenciatura em Artes Cênicas: volume 1. Goiânia: Funape/Ciar, 2010.

MARTINI, Cristiane Oliveira Pisani. Regule-se, exercite-se, embeleze-se: pedagogias para o corpo feminino pelo discurso da Revista Alterosa (1939-1964). 258f. 2017. Tese (Doutorado). Universidade Federal de Minas Gerais.

MELATTI, Sheila Pérsia do Prado Cardoso. A arquitetura escolar e a prática pedagógica. 120f. 2004. Dissertação (Mestrado em Educação e Cultura). Universidade do Estado de Santa Catarina, Joinville, 2004.

MENDES, Vanderlei da Silva. Os corpos e os processos de docilização na educação: uma leitura foucaultiana. 112f. 2014. Dissertação (Mestrado). Universidade do Extremo Sul Catarinense.

MORAES, Danielle Rodrigues de. Teatro na escola: Da lei à lida. Dissertação de mestrado. São João Del-Rei: UFSJ, 2011.

MORAES, Claudia Emilia Aguiar. A educação do corpo à beira-mar: esporte e modernidade na Ilha de Santa Catarina (1857-1932). 280f. 2017. Tese (Doutorado). Universidade Federal de Santa Catarina. 
MOREL, Márcia. A educação do corpo no Projeto Anisiano de Educação. 208f. 2016. Tese (Doutorado). Universidade Federal do Rio de Janeiro.

MOURA, E.A.; MATA, M.S.; PAULINO, P.R.V.; FREITAS, A.P.; JÚNIOR, C.A.M.; MÁRMORA, C.H.C. Os planos genéticos do desenvolvimento humano: a contribuição de Vigotski. Revista Educação e Desenvolvimento Humano. UNITAU, Taubaté/SP, v. 9, n 1, edição 16, p. 106 - 114, Jun. 2016.

NICOLINO, Aline da Silva; DIAS, Cleber; BAPTISTA, Tadeu João Ribeiro. Antropologia do corpo. In: FILHO, Ari Lazzarotti. (Org.). Licenciatura em Educação Física: volume 4. Goiânia: Gráfica UFG, 2014.

OLIVEIRA, Luciane Paiva Alves de. Violência, corpo e escolarização: apontamentos a partir da teoria crítica da sociedade. In: OLIVEIRA, Marcus Aurelio Taborda de. Educação do corpo na escola brasileira. Campinas: Autores Associados, 2006.

PANIZZI, Alan David Evaristo. Experimentações corporais como produtoras de (re)existência frente à futilidade presente na estética das práticas pedagógicas. 108f. 2016. Dissertação (Mestrado). Universidade Comunitária da Região do Chapecó.

PANOFSKY, Erwin. Iconografia e iconologia: uma introdução ao estudo da arte da renascença. In: . Significado nas Artes visuais. São Paulo: Perspectiva, 1991.

PINTO, A.C. Memória, cognição e educação: implicações mútuas. In: DETRY, B. e SIMAS, F. Educação, cognição e desenvolvimento: textos de psicologia educacional para a formação de professores. Pag. 17-54. Lisboa: Edinova, 2001.

PONTES, Bruno. "Eu sou essa! Eu sou esse!” Corpos, perspectivas e minúcias teatrais na pequena infância. 143f. 2016. Dissertação (Mestrado). Universidade Federal de Minas Gerais.

PRODANOV, C. C. Metodologia do trabalho científico: métodos e técnicas da pesquisa e do trabalho acadêmico. $2^{\mathrm{a}}$ ed. Novo Hamburgo: Feevale, 2013.

RAIMANN, Elizabeth Gottschalg; RAIMANN, Cristiane. Arquitetura escolar na produção de subjetividades. Revista Itinerarius. Vol. II, nº5. Jul-Dez 2008.

RANNIERY, Thiago. Corpos feitos de plástico, pó e glitter: currículos para dicções heterogêneas e visibilidades improváveis. 413f. 2016. Tese (Doutorado). Universidade do Estado do Rio de Janeiro.

REIS, A. S.; ARAUJO, I. I.; TORRES, T. C. Pichação no espaço escolar: um desafio político. Revista Interdisciplinar Internacional de Artes Visuais. Curitiba, v.5, n.1, p.104-118, Jan./Jun. 2018.

RIBEIRO, E. "Para que esse drama?": transversalidade no ensino de teatro. Dissertação de mestrado. UNICENTRO: Irati, 2014. 
RIOS, F. T. A.; MOREIRA, W. W. A importância do corpo no processo de ensino e aprendizagem. Revista Evidência. Araxá, v.11, n.11, p.49-58, 2015.

SANTANA, T. M. A relação da arquitetura escolar com a aprendizagem. IV Colóquio Internacional Educação e Contemporaneidade. Laranjeiras: 2010.

SANTIN, S. Educação e sensibilidade. Santa Maria, out. 1997. Disponível em: <http://labomidia.ufsc.br/Santin/Filosofia/Educa\%C3\%A7ao_e_Sensibilidade.pdf>.

SANTOS, Anderson Carvalho dos. Fortalecimento do corpo e educação dos sentidos: as primeiras lições de Rousseau para a formação do Emílio Antônomo. 94f. 2016. Universidade Federal de Goiás.

SANTOS, Maria Valéria Rodrigues dos. Uma professora de arte em trans-formação: corpos e materialidades. 135f. 2014. Dissertação (Mestrado). Instituto Federal de Educação, Ciência e Tecnologia Sul-Riograndense.

SANTOS, Verônica Valério. Por uma educação da sensibilidade: narrativa, mito, memória e transcendência em Cinema Paradiso. 143f. 2013. Dissertação (Mestrado). Universidade de Brasília.

SANTOS, Weslaine Alline da Silva Faria. Educação do corpo: um inventário de seus temas, autores e recortes. 89f. 2017. Dissertação (Mestrado). Universidade Federal de Goiás.

SARMENTO, N.R.G. A afetividade e a aprendizagem. Universidade Federal do Rio Grande do Sul. 34f. Trabalho do Conclusão de Curso de Pedagogia. Porto Alegre: 2010.

SEHN, Carina. Um corpo performático para romper com a representação. 95f. 2014. Dissertação (Mestrado). Universidade Federal do Rio Grande do Sul.

SILVA, Aline Ferraz da. Currículo e diferença: cartografia de um corpo travesti. 104f. 2014. Tese (Doutorado). Universidade Federal de Pelotas.

SILVA, M. A. A. Alforria pelo sensível: corporeidade da criança e formação docente. 254f. 2013. Tese (Doutorado). Universidade Federal de Goiás.

SILVA, Bruna da. Reflexões sobre corpo infantil nas práticas educativas do $1^{\circ}$ Ano do Ensino Fundamental: o lugar do movimento em pauta. 140f. 2017. Dissertação (Mestrado). Universidade Metodista de Piracicaba.

SILVA, Priscilla Stuart da. Educação estética: corpo, experiência e memória em Walter Benjamin. 125f. 2013. Dissertação (Mestrado). Universidade Federal de Santa Catarina.

SILVA, M. D. S.; WEISS, S. L. I. O corpo na escola e na vida: a educação corporal e seus efeitos no indivíduo. Revista de divulgação técnico-científica do ICPG. São Paulo, v.2, n.5, p.79-83, abr./jun. 2004. 
SILVEIRA, T. S. Teatro na escola: Possibilidades de uma "prática educativo- crítica". Acesso em: 20 de maio 2009.

SOARES, Mei Hua. Práticas de leitura no teatro de grupo: aproximações com a escola. Tese de doutorado. USP: São Paulo-SP, 2014.

SCHAEFER, Katia de Souza e Almeida Bizzo. O corpo como vontade de potência (em experiências) na educação infantil e nos primeiros anos do ensino fundamental. 179f. 2015. Tese (Doutorado). Universidade do Estado do Rio de Janeiro.

STRAZZACAPPA, Márcia. A educação e a fábrica de corpos: a dança na escola. Caderno Cedes, Ano XXI, n53, abril, 2001.

STROHER, Jonathan. O trabalho com o corpo/aluno na educação física escolar sob a óptica dos discentes do curso de licenciatura em educação física da UNEMAT/Cáceres: um estudo de representações sociais. 101f. 2014. Dissertação (Mestrado). Universidade Federal do Mato Grosso.

SURDI, Aguinaldo Cesar. Educação e sensibilidade: o brincar e o se movimentar da criança pequena na escola. Natal: EDUFRN, 2018.

TABORDA DE OLIVEIRA, Marcus Aurelio (Org.). Educação do corpo na escola brasileira. Campinas: Autores Associados, 2006.

TIBALLI, E. F. A; JORGE, L. E. A etnofotografia como meio de conhecimento no campo da educação. Revista Habitus. Goiânia, v.5, n.1, p.63-76, jan./jun. 2007.

TOFOLI, Heloisa Helena. Políticas públicas em educação: a presença do corpo na educação brasileira - 2000 a 2012. 85f. 2013. Dissertação (Mestrado). Universidade Cidade de São Paulo.

TOMAZETT, Luciano de Castro. A marca no corpo: futebol, tatuagem e educação. 169f. 2017. Dissertação (Mestrado). Universidade Federal de Goiás.

VALGAS, Aline Flávia. A relação entre a educação do corpo no Brasil da Primeira República e os contos de Lima Barreto. 115f. 2016. Universidade Federal de Goiás.

VAZ, T. Pichação + arte + educação: outros olhares. Revista Digital do LAV. Santa Maria, Ano VI, n.10, p.85-97, mar. 2013.

WAINER, João. Pichação é arte. Super Interessante, São Paulo, n. 213, p.98, abril/maio 2005.

ZAGO, Luiz Felipe. Os meninos: corpo, gênero e sexualidade em e através de um site de relacionamentos. 332f. 2013. Tese (Doutorado). Universidade Federal do Rio Grande do Sul. 
ANEXOS 
Quadro 1 - Síntese da análise das teses e dissertações da BDTD-Capes, realizado em setembro de 2018.

\begin{tabular}{|c|c|c|c|}
\hline INSTITUIÇÃO & TÍTULO & AUTOR/ANO & RESUMO/CONCLUSÃO \\
\hline $\begin{array}{l}\text { Universidade } \\
\text { Federal de } \\
\text { Santa Maria }\end{array}$ & $\begin{array}{c}\text { CORPO E CULTURA } \\
\text { DE MOVIMENTO NO } \\
\text { TEATRO DA } \\
\text { FORMAÇÃO } \\
\text { CULTURAL: AINDA } \\
\text { ULISSES? }\end{array}$ & $\begin{array}{l}\text { BACCIN, } \\
\text { Adriana } \\
\text { Nolibos } \\
(2013)\end{array}$ & $\begin{array}{l}\text { Discute sobre a formação } \\
\text { cultural do professor de } \\
\text { Educação Física no viés } \\
\text { da estética, por meio de } \\
\text { alguns procedimentos } \\
\text { corporais como o esporte, } \\
\text { o espetáculo, a cultura de } \\
\text { movimento e a reificação } \\
\text { do corpo. Trata-se de uma } \\
\text { pesquisa bibliográfica e } \\
\text { com bases teóricas em } \\
\text { Theodoro Adorno. }\end{array}$ \\
\hline $\begin{array}{l}\text { Universidade } \\
\text { Federal do Rio } \\
\text { Grande do } \\
\text { Norte }\end{array}$ & $\begin{array}{c}\text { CONHECIMENTOS } \\
\text { SOBRE O CORPO: } \\
\text { UMA } \\
\text { POSSIBILIDADE DE } \\
\text { INTERVENÇÃO } \\
\text { PEDAGÓGICA NAS } \\
\text { AULAS DE } \\
\text { EDUCAÇÃO FÍSICA } \\
\text { NO ENSINO MÉDIO }\end{array}$ & $\begin{array}{l}\text { BATISTA, } \\
\text { Alison Pereira } \\
\text { (2013) }\end{array}$ & $\begin{array}{l}\text { Tem por finalidade } \\
\text { refletir sobre o corpo e os } \\
\text { processos de ensino e } \\
\text { aprendizagem em } \\
\text { Educação Física no } \\
\text { Ensino Médio. Concebida } \\
\text { no campo da Educação } \\
\text { Física Escolar, a presente } \\
\text { pesquisa relata a } \\
\text { experiência de uma } \\
\text { intervenção pedagógica } \\
\text { interessada no } \\
\text { entendimento dos } \\
\text { estudantes sobre questões } \\
\text { como: a influência da } \\
\text { mídia no corpo dos } \\
\text { adolescentes; o uso de } \\
\text { anabolizantes; práticas de } \\
\text { relaxamento corporal; } \\
\text { dentre outros }\end{array}$ \\
\hline $\begin{array}{l}\text { Universidade } \\
\text { Federal de } \\
\text { Minas Gerais }\end{array}$ & $\begin{array}{c}\text { A EDUCAÇÃO } \\
\text { FÍSICA EM CENA: } \\
\text { OLHARES SOBRE O } \\
\text { COLÉGIO } \\
\text { ESTADUAL DE } \\
\text { MINAS GERAIS } \\
(1956-1973)\end{array}$ & $\begin{array}{c}\text { ARANTES, } \\
\text { Gabriela } \\
\text { Villela } \\
(2013)\end{array}$ & $\begin{array}{l}\text { Descreve o processo } \\
\text { histórico da disciplina } \\
\text { Educação Física no } \\
\text { Colégio Estadual de } \\
\text { Minas Gerais, a fim de } \\
\text { demonstrar os caminhos }\end{array}$ \\
\hline
\end{tabular}




\begin{tabular}{|c|c|c|c|}
\hline & & & $\begin{array}{l}\text { percorridos por esta } \\
\text { disciplina na educação do } \\
\text { corpo. Ao fazer uso de } \\
\text { procedimentos } \\
\text { documentais e entrevistas } \\
\text { com sujeitos da história } \\
\text { da instituição, a pesquisa } \\
\text { revela o caráter regulador } \\
\text { e esportista da Educação } \\
\text { Física dessa escola. }\end{array}$ \\
\hline $\begin{array}{c}\text { Universidade } \\
\text { Cidade de São } \\
\text { Paulo }\end{array}$ & $\begin{array}{c}\text { POLÍTICAS } \\
\text { PÚBLICAS EM } \\
\text { EDUCAÇÃO: A } \\
\text { PRESENÇA DO } \\
\text { CORPO NA } \\
\text { EDUCAÇÃO } \\
\text { BRASILEIRA - } 2000 \text { A } \\
2012\end{array}$ & $\begin{array}{c}\text { TOFOLI, } \\
\text { Heloisa } \\
\text { Helena } \\
(2013)\end{array}$ & $\begin{array}{l}\text { Busca compreensões para } \\
\text { o termo corpo na } \\
\text { educação brasileira entre } \\
\text { os anos de } 200 \text { e } 2012 \text {. A } \\
\text { pesquisa partiu da } \\
\text { experiência da autora } \\
\text { como fisioterapeuta no } \\
\text { atendimento de pacientes } \\
\text { em idade escolar que } \\
\text { apresentaram problemas } \\
\text { de coluna/postura. }\end{array}$ \\
\hline $\begin{array}{l}\text { Universidade } \\
\text { Estadual de } \\
\text { Campinas }\end{array}$ & $\begin{array}{c}\text { AS PRÁTICAS } \\
\text { CORPORAIS NO } \\
\text { TRABALHO DO } \\
\text { PROFESSOR DE } \\
\text { ARTE: UM ESTUDO } \\
\text { EM VÁRZEA } \\
\text { PAULISTA/SP }\end{array}$ & $\begin{array}{c}\text { ANGELO, } \\
\text { Marina } \\
\text { Balastreire } \\
(2013)\end{array}$ & $\begin{array}{l}\text { Analisa a atuação dos } \\
\text { professores de arte em } \\
\text { sala de aula, no que tange } \\
\text { ao corpo da criança, em } \\
\text { uma escola pública da } \\
\text { cidade de Várzea } \\
\text { Paulista/SP. Para isso, } \\
\text { busca compreensões } \\
\text { acerca dos espaços } \\
\text { escolares destinados à } \\
\text { livre manifestação do } \\
\text { corpo, afirmando a } \\
\text { relevância da arte para o } \\
\text { desenvolvimento da } \\
\text { corporeidade da criança } \\
\text { de modo a priorizar a } \\
\text { educação dos sentidos }\end{array}$ \\
\hline $\begin{array}{l}\text { Universidade } \\
\text { Federal do Rio } \\
\text { Grande do } \\
\text { Norte }\end{array}$ & $\begin{array}{c}\text { POR UMA } \\
\text { EDUCAÇÃO DOS } \\
\text { SENTIDOS: UM } \\
\text { DIÁLOGO ENTRE } \\
\text { MERLEAU-PONTY E } \\
\text { UESHIBA }\end{array}$ & $\begin{array}{l}\text { JUNIOR, } \\
\text { Moaldecir } \\
\text { Freire } \\
\text { Domingos } \\
(2013)\end{array}$ & $\begin{array}{l}\text { A presente pesquisa } \\
\text { realiza uma investigação } \\
\text { teórica sobre o corpo nos } \\
\text { trabalhos de Merleau- } \\
\text { Ponty (1908-1961) e de } \\
\text { Morihei Ueshiba (1883- }\end{array}$ \\
\hline
\end{tabular}




\begin{tabular}{|c|c|c|c|}
\hline & & & $\begin{array}{l}\text { 1969). Com a finalidade } \\
\text { de dialogar sobre alguns } \\
\text { embates de teorias do } \\
\text { conhecimento sobre corpo } \\
\text { e natureza, bem como } \\
\text { suas movimentações no } \\
\text { campo da educação e da } \\
\text { educação física, o } \\
\text { trabalho se debruça sobre } \\
\text { a educação dos sentidos, } \\
\text { do sensível, do invisível, } \\
\text { do diálogo e do silêncio. }\end{array}$ \\
\hline $\begin{array}{c}\text { Universidade } \\
\text { Federal de } \\
\text { Santa } \\
\text { Catarina }\end{array}$ & $\begin{array}{c}\text { EDUCAÇÃO } \\
\text { ESTÉTICA: CORPO, } \\
\text { EXPERIÊNCIA E } \\
\text { MEMÓRIA EM } \\
\text { WALTER BENJAMIN }\end{array}$ & $\begin{array}{l}\text { SILVA, } \\
\text { Priscilla } \\
\text { Stuart da } \\
(2013)\end{array}$ & $\begin{array}{l}\text { Discute a noção de uma } \\
\text { educação estética em } \\
\text { Walter Benjamin, } \\
\text { demonstrando, por meio } \\
\text { das fontes bibliográficas } \\
\text { utilizadas, o lugar do } \\
\text { corpo na formação de } \\
\text { uma nova constituição da } \\
\text { subjetividade humana. } \\
\text { Para a realização desta } \\
\text { tarefa, os conceitos de } \\
\text { experiência, memória e } \\
\text { sentidos são analisados } \\
\text { em duas obras de } \\
\text { Benjamin. A pesquisa } \\
\text { conclui que a tríade dos } \\
\text { conceitos sucinta uma } \\
\text { pedagogia da } \\
\text { corporalidade. }\end{array}$ \\
\hline $\begin{array}{l}\text { Universidade } \\
\text { de Brasília }\end{array}$ & $\begin{array}{c}\text { POR UMA } \\
\text { EDUCAÇÃO DA } \\
\text { SENSIBILIDADE: } \\
\text { NARRATIVA, MITO, } \\
\text { MEMÓRIA E } \\
\text { TRANSCENDÊNCIA } \\
\text { EM CINEMA } \\
\text { PARADISO }\end{array}$ & $\begin{array}{c}\text { SANTOS, } \\
\text { Verônica } \\
\text { Valério } \\
(2013)\end{array}$ & $\begin{array}{c}\text { Aborda a linguagem } \\
\text { cinematográfica e suas } \\
\text { contribuições para uma } \\
\text { educação da } \\
\text { sensibilidade, por } \\
\text { considerar o cinema como } \\
\text { um elemento catalizador e } \\
\text { propulsor de saberes } \\
\text { sensíveis. Para isso, } \\
\text { realiza uma análise do } \\
\text { filme Cinema Paradiso de } \\
\text { Giuseppe Tornatore } \\
\text { (1988) }\end{array}$ \\
\hline
\end{tabular}




\begin{tabular}{|c|c|c|c|}
\hline $\begin{array}{l}\text { Universidade } \\
\text { Estadual de } \\
\text { Campinas }\end{array}$ & $\begin{array}{c}\text { O CORPO NA } \\
\text { EDUCAÇÃO } \\
\text { EMANCIPATÓRIA } \\
\text { DA SEXUALIDADE: } \\
\text { UMA ANÁLISE DAS } \\
\text { INICIATIVAS DO } \\
\text { GOVERNO DO } \\
\text { PARANÁ (2008-2009) }\end{array}$ & $\begin{array}{c}\text { JUNIOR, } \\
\text { Aurélio Bona } \\
\text { (2013) }\end{array}$ & $\begin{array}{l}\text { Realiza uma análise sobre } \\
\text { o conceito de corpo } \\
\text { presente nos Cadernos } \\
\text { Temáticos da } \\
\text { Diversidade: sexualidade } \\
\text { publicados pelo governo } \\
\text { do Estado do Paraná em } \\
\text { 2009. A referida pesquisa } \\
\text { procura classificar o } \\
\text { conceito de corpo dentro } \\
\text { das abordagens histórico- } \\
\text { críticas e dialéticas. Nesse } \\
\text { processo, a corporalidade } \\
\text { emerge como elemento } \\
\text { fundamental à } \\
\text { sexualidade, sendo } \\
\text { discutido pelo autor ao } \\
\text { longo do trabalho. }\end{array}$ \\
\hline $\begin{array}{l}\text { Universidade } \\
\text { Federal do Rio } \\
\text { Grande do Sul }\end{array}$ & $\begin{array}{c}\text { OS MENINOS: } \\
\text { CORPO, GÊNERO E } \\
\text { SEXUALIDADE EM E } \\
\text { ATRAVÉS DE UM } \\
\text { SITE DE } \\
\text { RELACIONAMENTOS }\end{array}$ & $\begin{array}{c}\text { ZAGO, Luiz } \\
\text { Felipe } \\
\text { (2013) }\end{array}$ & $\begin{array}{l}\text { Reflete sobre o conceito } \\
\text { de corpo, gênero e } \\
\text { sexualidade à partir de um } \\
\text { site de relacionamentos, } \\
\text { com o objetivo de } \\
\text { demonstrar as qualidades } \\
\text { dos vínculos entre os } \\
\text { frequentadores do site; as } \\
\text { posições políticas; e as } \\
\text { suas subjetividades. }\end{array}$ \\
\hline $\begin{array}{l}\text { Universidade } \\
\text { Federal de } \\
\text { Minas Gerais }\end{array}$ & $\begin{array}{c}\text { O CORPO EM CENA } \\
\text { NA EDUCAÇÃO DE } \\
\text { JOVENS E ADULTOS: } \\
\text { A MOBILIZAÇÃO } \\
\text { PARA A } \\
\text { APRENDIZAGEM NA } \\
\text { EJA POR MEIO DOS } \\
\text { SIGNIFICADOS } \\
\text { EXPRESSOS PELA } \\
\text { CORPOREIDADE DE } \\
\text { MULHERES } \\
\text { ADULTAS }\end{array}$ & $\begin{array}{l}\text { FERREIRA, } \\
\text { Luiz Olavo } \\
\text { Fonseca } \\
(2013)\end{array}$ & $\begin{array}{c}\text { Aborda uma experiência } \\
\text { realizada com estudantes } \\
\text { da EJA de uma escola } \\
\text { pública de Belo } \\
\text { Horizonte/MG, da qual } \\
\text { investiga o vínculo da } \\
\text { corporalidade com as } \\
\text { questões de gênero por } \\
\text { meio de jogos teatrais. Os } \\
\text { dados coletados foram } \\
\text { analisados a partir dos } \\
\text { conceitos de maternidade, } \\
\text { família, trabalho } \\
\text { doméstico, trabalho fora }\end{array}$ \\
\hline
\end{tabular}




\begin{tabular}{|c|c|c|c|}
\hline & & & $\begin{array}{l}\text { de casa e espaço urbano. } \\
\text { Ao realizar esta análise, a } \\
\text { referida pesquisa } \\
\text { evidencia a dificuldade de } \\
\text { se trabalhar a experiência } \\
\text { do corpo na EJA por } \\
\text { conta da existência de } \\
\text { corpos disciplinados e } \\
\text { engessados. }\end{array}$ \\
\hline $\begin{array}{l}\text { Universidade } \\
\text { Federal de } \\
\text { Goiás }\end{array}$ & $\begin{array}{c}\text { ALFORRIA PELO } \\
\text { SENSÍVEL: } \\
\text { CORPOREIDADE DA } \\
\text { CRIANÇA E } \\
\text { FORMAÇÃO } \\
\text { DOCENTE }\end{array}$ & $\begin{array}{l}\text { SILVA, Maria } \\
\text { Aparecida } \\
\text { Alves da } \\
\text { (2013) }\end{array}$ & $\begin{array}{l}\text { Procurou a construção de } \\
\text { fundamentos pedagógicos } \\
\text { para uma formação } \\
\text { docente que contribua } \\
\text { para a desnaturalização da } \\
\text { violência física } \\
\text { intrafamiliar como } \\
\text { método educativo } \\
\text { punitivo disciplinar. No } \\
\text { decorrer do trabalho, a } \\
\text { autora aborda a } \\
\text { corporeidade como via de } \\
\text { construção de } \\
\text { conhecimentos sensíveis. }\end{array}$ \\
\hline $\begin{array}{l}\text { Universidade } \\
\text { Federal do Rio } \\
\text { Grande do Sul }\end{array}$ & $\begin{array}{c}\text { UM CORPO } \\
\text { PERFORMÁTICO } \\
\text { PARA ROMPER COM } \\
\text { A REPRESENTAÇÃO }\end{array}$ & $\begin{array}{c}\text { SEHN, Carina } \\
\text { (2014) }\end{array}$ & $\begin{array}{c}\text { A pesquisa trata do corpo } \\
\text { performático e sua relação } \\
\text { com a imagem, situando- } \\
\text { se no campo da arte, da } \\
\text { educação e da filosofia. } \\
\text { Aborda o problema da } \\
\text { imagem como } \\
\text { representação } \\
\text { estratificada e } \\
\text { moralizante. A } \\
\text { pesquisadora conclui que } \\
\text { o corpo performático se } \\
\text { cria e se reproduz } \\
\text { sucessivamente. }\end{array}$ \\
\hline $\begin{array}{l}\text { Universidade } \\
\text { Federal do } \\
\text { Mato Grosso }\end{array}$ & $\begin{array}{c}\text { O TRABALHO COM } \\
\text { O CORPO/ALUNO NA } \\
\text { EDUCAÇÃO FÍSICA } \\
\text { ESCOLAR SOB A } \\
\text { ÓPTICA DOS } \\
\text { DISCENTES DO } \\
\text { CURSO DE }\end{array}$ & $\begin{array}{l}\text { STROHER, } \\
\text { Jonathan } \\
\text { (2014) }\end{array}$ & $\begin{array}{l}\text { Analisa as representações } \\
\text { sociais que discentes do } \\
\text { curso de licenciatura em } \\
\text { Educação Física da } \\
\text { Universidade do Estado } \\
\text { do Mato Grosso possuem }\end{array}$ \\
\hline
\end{tabular}




\begin{tabular}{|c|c|c|c|}
\hline & $\begin{array}{c}\text { LICENCIATURA EM } \\
\text { EDUCAÇÃO FÍSICA } \\
\text { DA } \\
\text { UNEMAT/CÁCERES: } \\
\text { UM ESTUDO DE } \\
\text { REPRESENTAÇÕES } \\
\text { SOCIAIS }\end{array}$ & & $\begin{array}{c}\text { acerca do trabalho com o } \\
\text { corpo na escola. } \\
\text { Embasado nesse } \\
\text { pressuposto, o autor } \\
\text { discute como o } \\
\text { corpo/aluno é trabalhado } \\
\text { na escola. }\end{array}$ \\
\hline $\begin{array}{c}\text { Universidade } \\
\text { Cidade de São } \\
\text { Paulo }\end{array}$ & $\begin{array}{c}\text { A CONSTRUÇÃO DO } \\
\text { SUJEITO } \\
\text { ENCARNADO NA } \\
\text { EXPERIÊNCIA } \\
\text { DOCENTE }\end{array}$ & $\begin{array}{l}\text { DINIZ, } \\
\text { Luciene } \\
\text { Teixeira } \\
(2014)\end{array}$ & $\begin{array}{l}\text { Apresenta a construção do } \\
\text { conhecimento sobre o } \\
\text { corpo ao longo da } \\
\text { história, de modo a } \\
\text { demonstrar que é pela } \\
\text { ação corporal que o } \\
\text { docente constrói a sua } \\
\text { trajetória. Segundo a } \\
\text { pesquisa, o sujeito que } \\
\text { vive em um corpo, pelo } \\
\text { movimento, e nesta ação } \\
\text { incorporada ele constrói } \\
\text { seus saberes como } \\
\text { docente, como um sujeito } \\
\text { ativo e presente no seu } \\
\text { tempo. }\end{array}$ \\
\hline $\begin{array}{c}\text { Universidade } \\
\text { Federal do Rio } \\
\text { de Janeiro }\end{array}$ & $\begin{array}{c}\text { LINGUAGEM } \\
\text { CORPORAL, } \\
\text { DOCÊNCIA E } \\
\text { TEORIA CRÍTICA }\end{array}$ & $\begin{array}{c}\text { ARAUJO, } \\
\text { Márcia Feijó } \\
\text { de } \\
(2014)\end{array}$ & $\begin{array}{c}\text { Analisa uma experiência } \\
\text { realizada com um grupo } \\
\text { de professores } \\
\text { participantes de um curso } \\
\text { de formação continuada } \\
\text { com ênfase na expressão } \\
\text { e na conscientização } \\
\text { corporal. Para isso, } \\
\text { discute as diversas } \\
\text { possibilidades de uma } \\
\text { educação corporal } \\
\text { emancipadora que, na } \\
\text { perspectiva da } \\
\text { pesquisadora, pode } \\
\text { ocorrer por meio de uma } \\
\text { maior compreensão do } \\
\text { corpo e de sua linguagem. }\end{array}$ \\
\hline
\end{tabular}




\begin{tabular}{|c|c|c|c|}
\hline $\begin{array}{c}\text { Instituto } \\
\text { Federal de } \\
\text { Educação, } \\
\text { Ciência e } \\
\text { Tecnologia } \\
\text { Sul- } \\
\text { Riograndense }\end{array}$ & $\begin{array}{c}\text { UMA PROFESSORA } \\
\text { DE ARTE EM TRANS- } \\
\text { FORMAÇÃO: } \\
\text { CORPOS E } \\
\text { MATERIALIDADES }\end{array}$ & $\begin{array}{c}\text { SANTOS, } \\
\text { Maria Valéria } \\
\text { Rodrigues dos } \\
\text { (2014) }\end{array}$ & $\begin{array}{l}\text { A presente pesquisa } \\
\text { problematiza as } \\
\text { experiências do sensível } \\
\text { na prática docente, } \\
\text { culminando na análise de } \\
\text { um corpo pedagógico que } \\
\text { opera no plano estético, } \\
\text { político e ético da vida. } \\
\text { Ademais, questiona o } \\
\text { corpo em suas relações } \\
\text { com matérias, } \\
\text { materialidades e } \\
\text { imaterialidades. }\end{array}$ \\
\hline $\begin{array}{c}\text { Universidade } \\
\text { do Extremo } \\
\text { Sul } \\
\text { Catarinense }\end{array}$ & $\begin{array}{c}\text { OS CORPOS E OS } \\
\text { PROCESSOS DE } \\
\text { DOCILIZAÇÃO NA } \\
\text { EDUCAÇÃO: UMA } \\
\text { LEITURA } \\
\text { FOUCAULTIANA }\end{array}$ & $\begin{array}{l}\text { MENDES, } \\
\text { Vanderlei da } \\
\text { Silva } \\
(2014)\end{array}$ & $\begin{array}{l}\text { Amparado nas ideias de } \\
\text { Foucault, a referida } \\
\text { pesquisa discute o } \\
\text { problema dos corpos no } \\
\text { processo educacional, } \\
\text { desenvolvendo reflexões } \\
\text { sobre os corpos dóceis e } \\
\text { disciplinados, o poder } \\
\text { disciplinar, o panoptismo } \\
\text { e o biopoder. Além disso, } \\
\text { a presente pesquisa } \\
\text { analisa a importância de } \\
\text { Foucault para a educação, } \\
\text { particularmente, sobre o } \\
\text { papel dos corpos, seu } \\
\text { disciplinamento e as } \\
\text { relações de poder } \\
\text { presentes na escola. }\end{array}$ \\
\hline $\begin{array}{l}\text { Universidade } \\
\text { Federal do Rio } \\
\text { Grande do Sul }\end{array}$ & $\begin{array}{c}\text { CORPO A DANÇAR: } \\
\text { ENTRE EDUCAÇÃO E } \\
\text { CRIAÇÃO DE } \\
\text { CORPOS }\end{array}$ & $\begin{array}{c}\text { FERRAZ, } \\
\text { Wagner } \\
(2014)\end{array}$ & $\begin{array}{l}\text { Aborda a dança como } \\
\text { uma possibilidade de } \\
\text { educar a si mesmo. Nesse } \\
\text { processo são investigadas } \\
\text { questões que emergem } \\
\text { entre a educação e a } \\
\text { criação de corpos; entre } \\
\text { sujeitos e subjetivações; } \\
\text { entre mensuráveis e } \\
\text { imensuráveis; entre } \\
\text { representações e } \\
\text { acontecimentos. }\end{array}$ \\
\hline
\end{tabular}




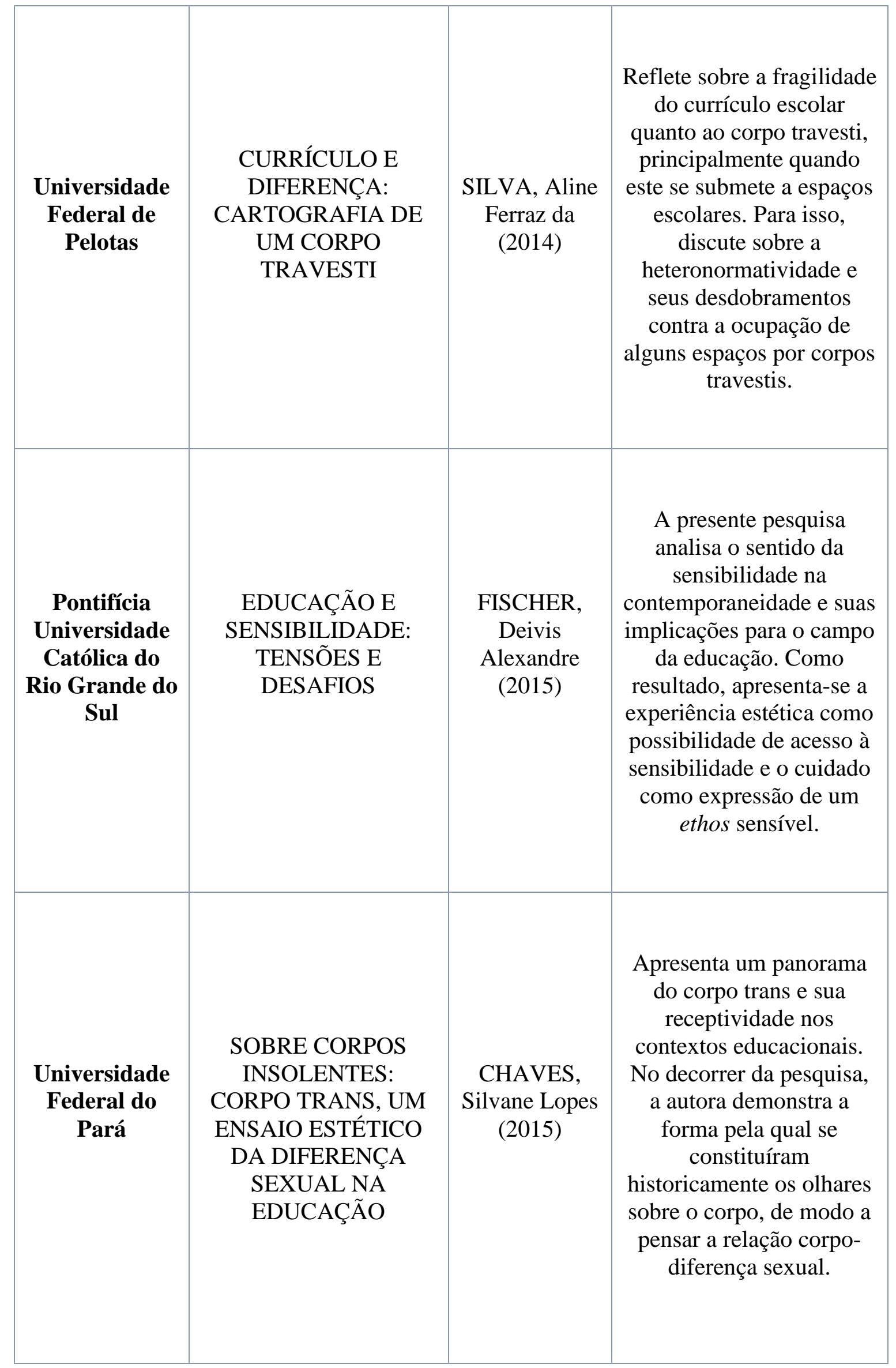




\begin{tabular}{|c|c|c|c|}
\hline $\begin{array}{c}\text { Universidade } \\
\text { do Estado do } \\
\text { Rio de Janeiro }\end{array}$ & $\begin{array}{c}\text { O CORPO COMO } \\
\text { VONTADE DE } \\
\text { POTÊNCIA (EM } \\
\text { EXPERIÊNCIAS) NA } \\
\text { EDUCAÇÃO } \\
\text { INTANTIL E NOS } \\
\text { PRIMEIROS ANOS } \\
\text { DO ENSINO } \\
\text { FUNDAMENTAL }\end{array}$ & $\begin{array}{l}\text { SCHAEFER, } \\
\text { Katia de } \\
\text { Souza e } \\
\text { Almeida } \\
\text { Bizzo } \\
(2015)\end{array}$ & $\begin{array}{c}\text { Reflete sobre as } \\
\text { experiências docentes de } \\
\text { uma professora da } \\
\text { Educação Infantil sobre o } \\
\text { olhar para o corpo como } \\
\text { vontade de potência. } \\
\text { Nesta pesquisa, o corpo é } \\
\text { visto como o fio condutor } \\
\text { da criação da vida de cada } \\
\text { sujeito. }\end{array}$ \\
\hline $\begin{array}{c}\text { Universidade } \\
\text { Comunitária } \\
\text { da Região de } \\
\text { Chapecó }\end{array}$ & $\begin{array}{c}\text { EXPERIMENTAÇÕES } \\
\text { CORPORAIS COMO } \\
\text { PRODUTORAS DE } \\
\text { (RE)EXISTÊNCIA } \\
\text { FRENTE À } \\
\text { FUTILIDADE } \\
\text { PRESENTE NA } \\
\text { ESTÉTICA DAS } \\
\text { PRÁTICAS } \\
\text { PEDAGÓGICAS }\end{array}$ & $\begin{array}{l}\text { PANIZZI, } \\
\text { Alan David } \\
\text { Evaristo } \\
\text { (2016) }\end{array}$ & $\begin{array}{l}\text { Trata-se de uma pesquisa } \\
\text { teórica que busca } \\
\text { compreender as } \\
\text { experimentações } \\
\text { corporais como meio de } \\
\text { produção de } \\
\text { (re)existência à futilidade } \\
\text { vivenciada na estética das } \\
\text { práticas pedagógicas. Na } \\
\text { concepção desta pesquisa, } \\
\text { a prática pedagógica } \\
\text { precisa ultrapassar a mera } \\
\text { funcionalidade dos } \\
\text { movimentos, agenciando } \\
\text { microssensibilidades } \\
\text { sobre eles. }\end{array}$ \\
\hline $\begin{array}{l}\text { Universidade } \\
\text { Federal de } \\
\text { Goiás }\end{array}$ & $\begin{array}{c}\text { A RELAÇÃO ENTRE } \\
\text { A EDUCAÇÃO DO } \\
\text { CORPO NO BRASIL } \\
\text { DA PRIMEIRA } \\
\text { REPÚBLICA E OS } \\
\text { CONTOS DE LIMA } \\
\text { BARRETO }\end{array}$ & $\begin{array}{c}\text { VALGAS, } \\
\text { Aline Flávia } \\
\text { (2016) }\end{array}$ & $\begin{array}{l}\text { Por intermédio dos contos } \\
\text { de Lima Barreto, a } \\
\text { presente pesquisa } \\
\text { investiga a educação do } \\
\text { corpo durante a Primeira } \\
\text { República do Brasil. Ao } \\
\text { analisar cerca de cento e } \\
\text { cinco contos de Lima } \\
\text { Barreto, a pesquisa revela } \\
\text { as tensões corporais } \\
\text { vivenciadas pelos sujeitos } \\
\text { no período retratado. }\end{array}$ \\
\hline
\end{tabular}




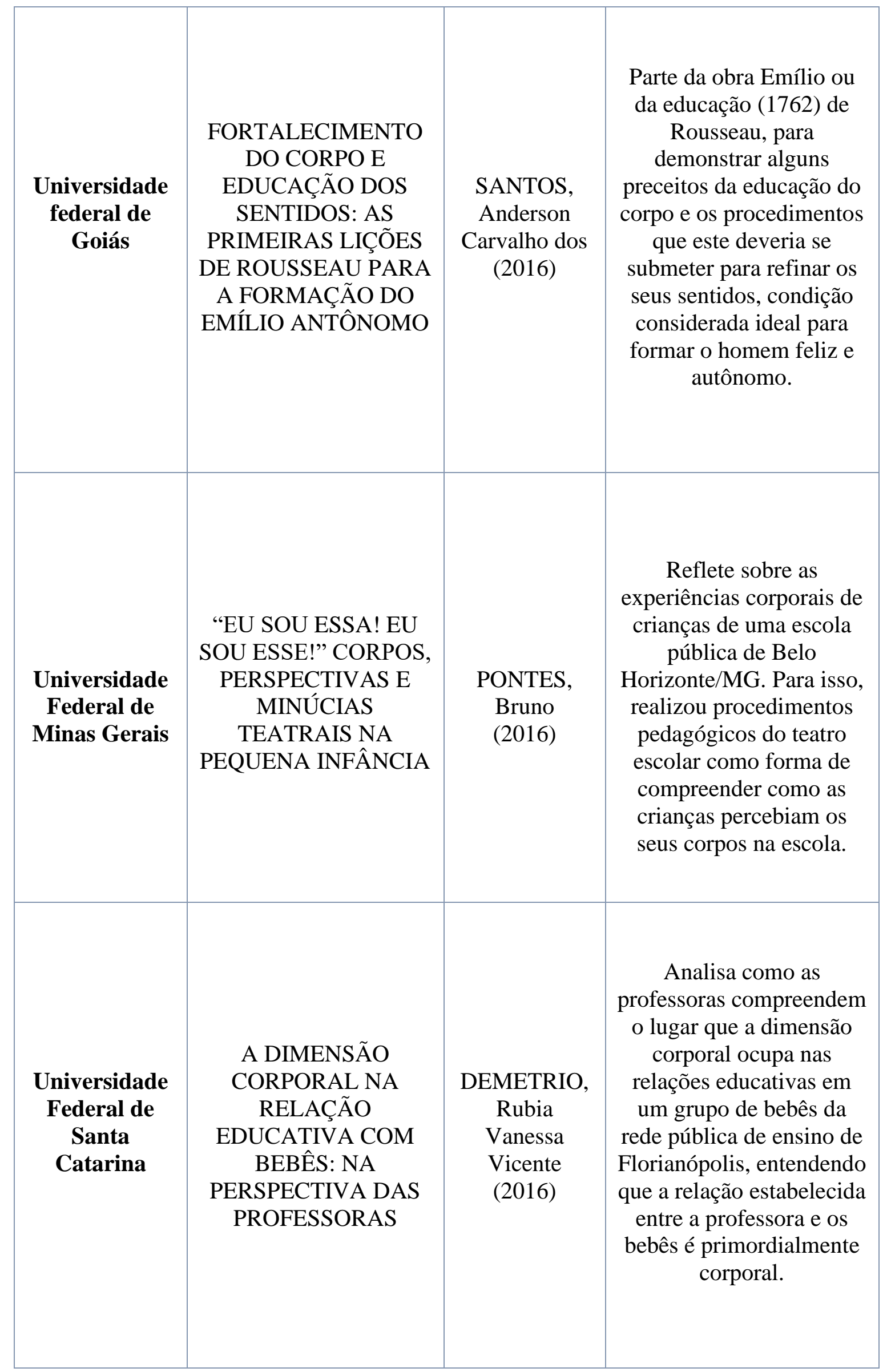




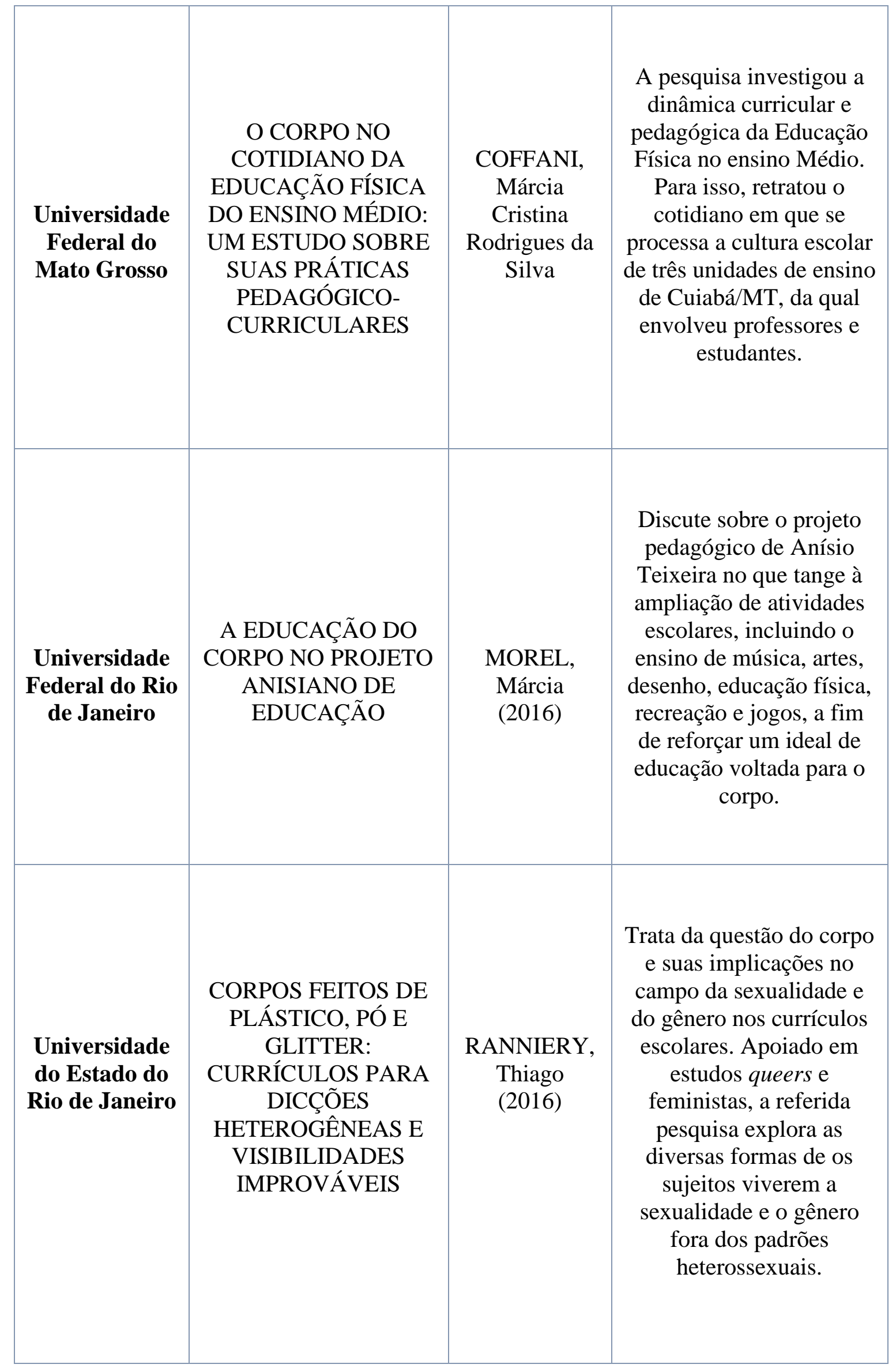




\begin{tabular}{|c|c|c|c|}
\hline $\begin{array}{l}\text { Universidade } \\
\text { Metodista de } \\
\text { Piracicaba }\end{array}$ & $\begin{array}{c}\text { REFLEXÕES SOBRE } \\
\text { CORPO INFANTIL } \\
\text { NAS PRÁTICAS } \\
\text { EDUCATIVAS DO } 1^{\circ} \\
\text { ANO DO ENSINO } \\
\text { FUNDAMENTAL: O } \\
\text { LUGAR DO } \\
\text { MOVIMENTO EM } \\
\text { PAUTA }\end{array}$ & $\begin{array}{c}\text { SILVA, Bruna } \\
\text { da } \\
(2017)\end{array}$ & $\begin{array}{l}\text { Busca compreensões para } \\
\text { as práticas escolares } \\
\text { referentes ao Ensino } \\
\text { Fundamental sobre as } \\
\text { ações do corpo infantil na } \\
\text { escola. Em síntese, a } \\
\text { pesquisa reflete sobre o } \\
\text { entendimento de como o } \\
\text { corpo infantil é } \\
\text { considerado na escola, de } \\
\text { modo a verificar se as } \\
\text { práticas educativas } \\
\text { apresentam tendências ao } \\
\text { silenciamento ou à } \\
\text { promoção de ações } \\
\text { corporais. }\end{array}$ \\
\hline $\begin{array}{l}\text { Universidade } \\
\text { Estadual de } \\
\text { Campinas }\end{array}$ & $\begin{array}{c}\text { EDUCAÇÃO DO } \\
\text { CORPO NA } \\
\text { PERSPECTIVA DE } \\
\text { GÊNERO: UMA } \\
\text { ANÁLISE DE } \\
\text { PROJETOS } \\
\text { PÚBLICOS DE } \\
\text { ESPORTE E LAZER }\end{array}$ & $\begin{array}{l}\text { FILHO, } \\
\text { Flavio de } \\
\text { Andrade } \\
\text { Benini } \\
(2017)\end{array}$ & $\begin{array}{l}\text { Analisa a relação entre a } \\
\text { educação do corpo e as } \\
\text { questões de gênero nas } \\
\text { práticas de esporte e lazer } \\
\text { da Secretaria de Esporte e } \\
\text { Lazer da cidade de } \\
\text { Campinas/SP. O objetivo } \\
\text { principal da pesquisa } \\
\text { centra-se na verificação } \\
\text { da dimensão da educação } \\
\text { do corpo nos projetos } \\
\text { desenvolvidos pela } \\
\text { referida secretaria e como } \\
\text { o gênero atravessa essas } \\
\text { práticas. A pesquisa } \\
\text { aponta que a educação do } \\
\text { corpo se difere para } \\
\text { meninos e para meninas } \\
\text { por conta de diferentes } \\
\text { fatores. }\end{array}$ \\
\hline $\begin{array}{l}\text { Universidade } \\
\text { Federal de } \\
\text { Goiás }\end{array}$ & $\begin{array}{c}\text { A MARCA NO } \\
\text { CORPO: FUTEBOL, } \\
\text { TATUAGEM E } \\
\text { EDUCAÇÃO }\end{array}$ & $\begin{array}{l}\text { TOMAZETT, } \\
\text { Luciano de } \\
\text { Castro } \\
(2017)\end{array}$ & $\begin{array}{l}\text { Reflete sobre o jogador de } \\
\text { futebol tatuado e suas } \\
\text { repercussões no campo } \\
\text { imagético. Assim, a } \\
\text { pesquisa interessou-se na } \\
\text { compreensão do modo } \\
\text { pelo qual o corpo se } \\
\text { constitui em objeto de }\end{array}$ \\
\hline
\end{tabular}




\begin{tabular}{|c|c|c|c|}
\hline & & & $\begin{array}{l}\text { realização de pertença } \\
\text { grupal dos torcedores no } \\
\text { âmbito futebolístico e } \\
\text { seus desdobramentos no } \\
\text { campo da educação. }\end{array}$ \\
\hline $\begin{array}{c}\text { Universidade } \\
\text { Tiradentes }\end{array}$ & $\begin{array}{c}\text { CORPO } \\
\text { REGULAMENTADO, } \\
\text { CORPO REBELADO: } \\
\text { ATHENEU } \\
\text { SERGIPENSE (1909- } \\
\text { 1911) }\end{array}$ & $\begin{array}{c}\text { AMADO, } \\
\text { Paula Barreto } \\
\text { Dória } \\
(2017)\end{array}$ & $\begin{array}{c}\text { A presente pesquisa } \\
\text { realiza um percurso } \\
\text { histórico no Colégio } \\
\text { Atheneu Sergipense a fim } \\
\text { de retratar a perspectiva } \\
\text { do corpo/corporeidade e } \\
\text { das normativas } \\
\text { controladoras realizadas } \\
\text { pela escola. Para isso, } \\
\text { busca respaldos no campo } \\
\text { da história da educação, } \\
\text { da filosofia pós-moderna } \\
\text { e da antropologia do } \\
\text { corpo. }\end{array}$ \\
\hline $\begin{array}{l}\text { Universidade } \\
\text { Federal de } \\
\text { Minas Gerais }\end{array}$ & $\begin{array}{c}\text { PROFESSORES DE } \\
\text { EDUCAÇÃO FÍSICA } \\
\text { FORMADOS EM } \\
\text { INSTITUIÇÕES } \\
\text { PRIVADAS E A } \\
\text { PROBLEMATIZAÇÃO } \\
\text { DO CORPO }\end{array}$ & $\begin{array}{l}\text { BARBOSA, } \\
\text { Pietrine Paiva } \\
(2017)\end{array}$ & $\begin{array}{l}\text { Aborda a noção de corpo } \\
\text { em Michael Foulcault } \\
\text { para pensar a educação } \\
\text { física escolar. Para isso, } \\
\text { analisa as obras de João } \\
\text { Paulo Medina, Jocimar } \\
\text { Daolio e Carmen Lucia } \\
\text { Soares, autores } \\
\text { renomados no campo da } \\
\text { educação física. A } \\
\text { pesquisa conclui } \\
\text { afirmando a existência de } \\
\text { duas formas diferentes de } \\
\text { problematizar o corpo e } \\
\text { fazer educação física na } \\
\text { escola. }\end{array}$ \\
\hline $\begin{array}{c}\text { Universidade } \\
\text { Federal de } \\
\text { Goiás }\end{array}$ & $\begin{array}{l}\text { EDUCAÇÃO DO } \\
\text { CORPO: UM } \\
\text { INVENTÁRIO DE } \\
\text { SEUS TEMAS, } \\
\text { AUTORES E } \\
\text { RECORTES }\end{array}$ & $\begin{array}{l}\text { SANTOS, } \\
\text { Weslaine } \\
\text { Alline da } \\
\text { Silva Faria } \\
\text { (2017) }\end{array}$ & $\begin{array}{c}\text { Discute sobre quais } \\
\text { incursões teóricas acerca } \\
\text { da educação do corpo tem } \\
\text { marcado a produção } \\
\text { científica das pesquisas } \\
\text { publicadas na Revista } \\
\text { Brasileira de Educação, } \\
\text { na Revista Brasileira de }\end{array}$ \\
\hline
\end{tabular}




\begin{tabular}{|c|c|c|c|}
\hline & & & $\begin{array}{l}\text { Ciências do Esporte e na } \\
\text { Revista Brasileira de } \\
\text { história da Educação entre } \\
\text { os anos de } 1997 \text { a } 2017 \text {. A } \\
\text { pesquisa apresenta } \\
\text { conclusões que } \\
\text { demonstram a fragilidade } \\
\text { teórica e epistemológica } \\
\text { expressas na dispersão e } \\
\text { generalização conceitual } \\
\text { de corpo. }\end{array}$ \\
\hline $\begin{array}{c}\text { Universidade } \\
\text { Federal de } \\
\text { Santa } \\
\text { Catarina }\end{array}$ & $\begin{array}{c}\text { A EDUCAÇÃO DO } \\
\text { CORPO Ȧ BEIRA- } \\
\text { MAR: ESPORTE E } \\
\text { MODERNIDADE NA } \\
\text { ILHA DE SANTA } \\
\text { CATARINA (1857- } \\
\text { 1932) }\end{array}$ & $\begin{array}{c}\text { MORAES, } \\
\text { Cláudia } \\
\text { Emilia Aguiar } \\
\text { (2017) }\end{array}$ & $\begin{array}{c}\text { Investiga as relações entre } \\
\text { o desenvolvimento } \\
\text { esportivo e os processos } \\
\text { de urbanização no período } \\
\text { de } 1857-1932 \text { em } \\
\text { Florianópolis. Para isso, } \\
\text { discute como a presença e } \\
\text { a ampliação das práticas } \\
\text { esportivas, sobretudo na } \\
\text { expressão do remo, } \\
\text { participaram na formação } \\
\text { de uma estrutura modelar } \\
\text { de educação do corpo. } \\
\text { Além disso, ainda debate } \\
\text { a relação entre corpo e } \\
\text { cidade, tendo como } \\
\text { referências as imagens } \\
\text { modernas da divulgação } \\
\text { das práticas corporais, o } \\
\text { desenvolvimento do } \\
\text { domínio esportivo e o } \\
\text { processo de urbanização. }\end{array}$ \\
\hline $\begin{array}{l}\text { Universidade } \\
\text { Federal de } \\
\text { Minas Gerais }\end{array}$ & $\begin{array}{c}\text { REGULE-SE, } \\
\text { EXERCITE-SE, } \\
\text { EMBELEZE-SE: } \\
\text { PEDAGOGIAS PARA } \\
\text { O CORPO FEMININO } \\
\text { PELO DISCURSO DA } \\
\text { REVISTA ALTEROSA } \\
(1939-1964)\end{array}$ & $\begin{array}{c}\text { MARTINI, } \\
\text { Cristiane } \\
\text { Oliveira } \\
\text { Pisani } \\
(2017)\end{array}$ & $\begin{array}{l}\text { Analisa as pedagogias } \\
\text { para o corpo feminino } \\
\text { propostas pelo discurso da } \\
\text { Revista Alterosa (1939- } \\
\text { 1964). A pesquisa revela } \\
\text { que tais pedagogias se } \\
\text { organizam em redes } \\
\text { complexas de } \\
\text { recomendações apoiadas } \\
\text { no discurso médico- } \\
\text { científico que, de modo } \\
\text { geral, se refinaram em } \\
\text { rituais, dietas, }\end{array}$ \\
\hline
\end{tabular}




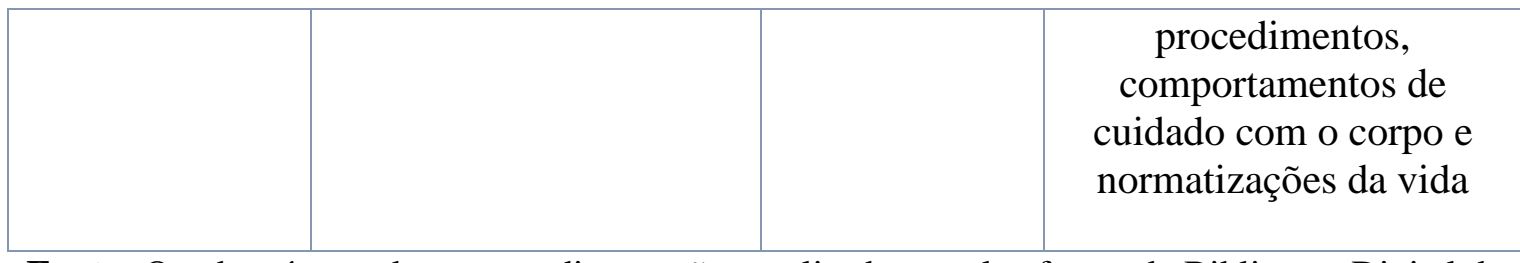

Fonte: Quadro síntese das teses e dissertações analisadas na plataforma da Biblioteca Digital de Teses e Dissertações (BDTD) da Capes, elaborada pelo pesquisador. 